Nevada

Environmental

Restoration

Project

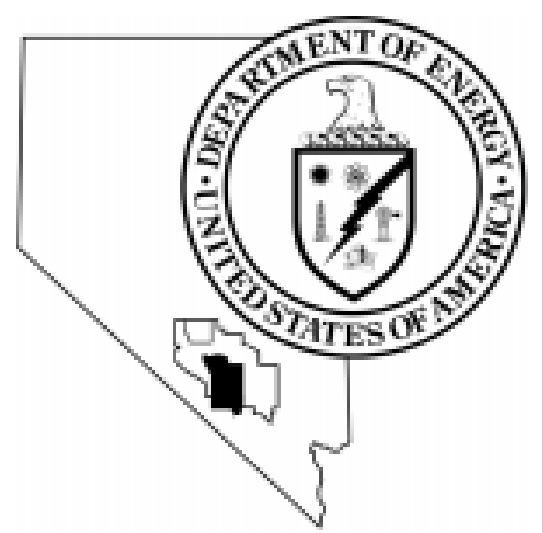

Streamlined Approach for

Environmental Restoration [SAFER] Plan

For Corrective Action Unit 356: Mud

Pits and Disposal Sites, Nevada Test

Site, Nevada

Controlled Copy No.:

Revision No.: 0

August 2001

Approved for public release; further dissemination unlimited.

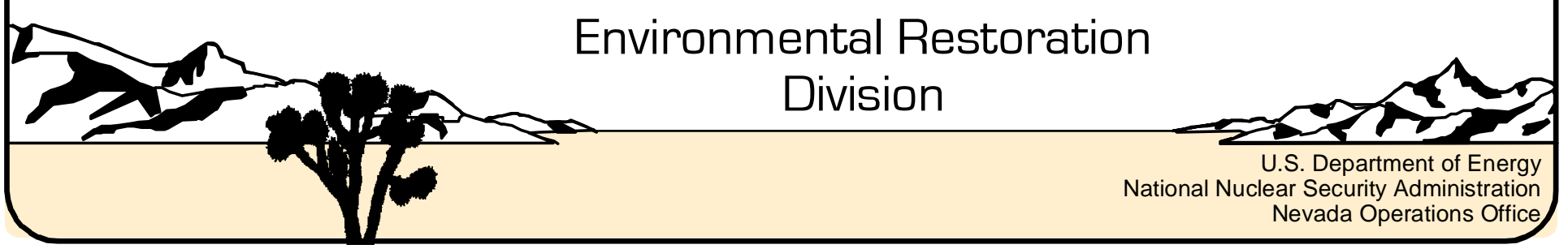


Available for public sale, in paper, from:

\author{
U.S. Department of Commerce \\ National Technology Information Service \\ 5285 Port Royal Road \\ Springfield, VA 22161 \\ Phone: 800.553 .6847 \\ Fax: 703.605.6900 \\ Email: orders@ntis.fedworld.gov \\ Online ordering: http://www.ntis.gov/ordering.htm
}

Available electronically at http://www.doe.gov/bridge.

Available for a processing fee to U.S. Department of Energy and its contractors, in paper, from:

\author{
U.S. Department of Energy \\ Office of Scientific and Technical Information \\ P.O. Box 62 \\ Oak Ridge, TN 37831-0062 \\ Phone: 865.576 .8401 \\ Fax: 865.576.5728 \\ Email: reports@adonis.osti.gov
}

Reference herein to any specific commercial product, process, or service by trade name, trademark, manufacturer, or otherwise, does not necessarily constitute or imply its endorsement, recommendation, or favoring by the United States Government or any agency thereof or its contractors or subcontractors. 


\title{
STREAMLINED APPROACH FOR ENVIRONMENTAL RESTORATION (SAFER) PLAN FOR CORRECTIVE ACTION UNIT 356: MUD PITS AND DISPOSAL SITES, NEVADA TEST SITE, NEVADA
}

\author{
U.S. Department of Energy \\ National Nuclear Security Administration \\ Nevada Operations Office \\ Las Vegas, Nevada
}

Controlled Copy No.:

Revision No.: 0

August 2001

Approved for public release; further dissemination unlimited. 
STREAMLINED APPROACH FOR ENVIRONMENTAL

RESTORATION (SAFER) PLAN FOR CORRECTIVE ACTION UNIT 356: MUD PITS AND DISPOSAL SITES, NEVADA TEST SITE, NEVADA

Approved by: Signature Approved

Date: $8 / 21 / 01$

Janet Appenzeller-Wing, Project Manager

Industrial Sites Project

Approved by: Signature Approved

Date: $8 / 21 / 01$

Runore C. Wycoff, Division Director

Environmental Restoration Division 


\section{Table of Contents}

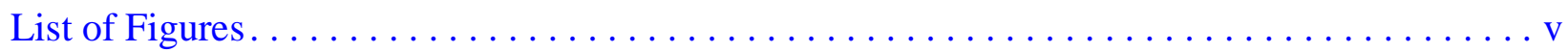

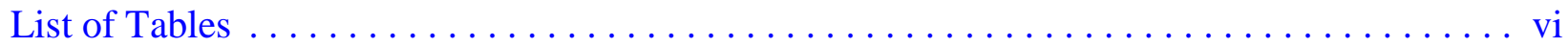

List of Acronyms and Abbreviations $\ldots \ldots \ldots \ldots \ldots \ldots \ldots \ldots \ldots \ldots \ldots \ldots \ldots \ldots \ldots \ldots \ldots$

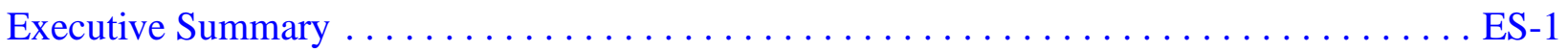

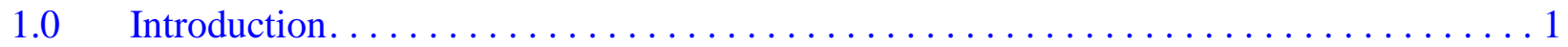

$1.1 \quad$ SAFER Process. . . . . . . . . . . . . . . . . . . . . 1

1.2 Summary of Corrective Actions . . . . . . . . . . . . . . . . . . . . 3

1.3 SAFER Work Plan Contents. . . . . . . . . . . . . . . . . . . . 5

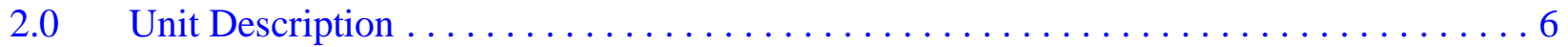

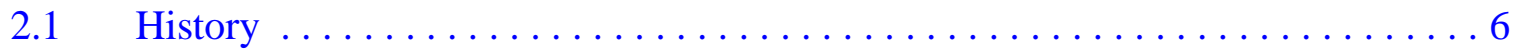

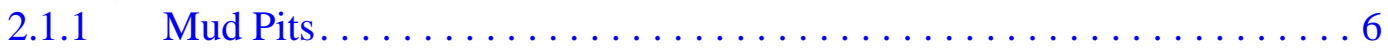

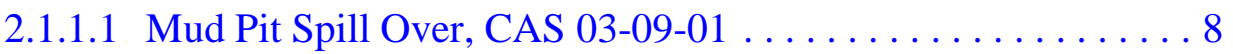

2.1.1.2 Mud Pit, CAS 03-09-03 ................

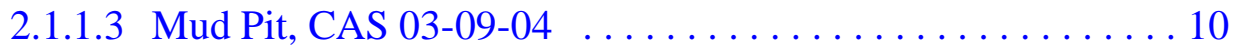

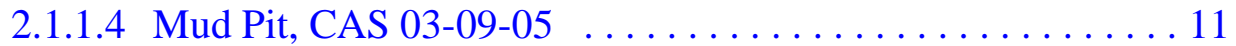

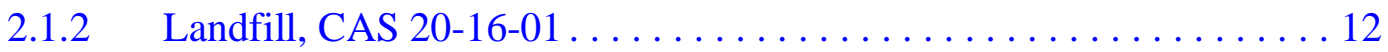

2.1.3 Area 3 Change House Septic System . . . . . . . . . . . . . . . 13

$2.2 \quad$ Site Location and Description. . . . . . . . . . . . . . . . 16

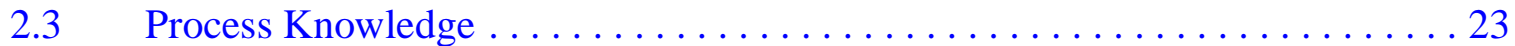

2.3.1 CSM for Mud Pits and Landfill . . . . . . . . . . . . . . . . 23

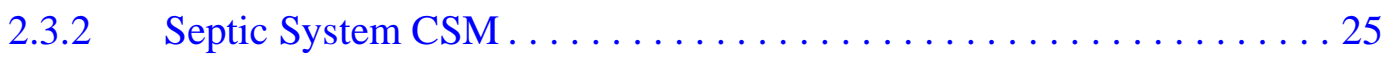

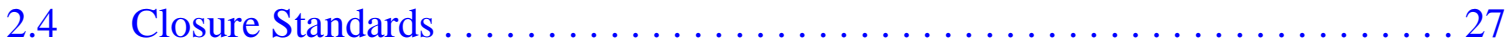

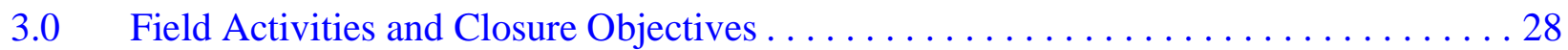

3.1 Contaminants of Potential Concern . . . . . . . . . . . . . . . . . . . . . . . . . . 29

3.2 Remediation ................................... 29

3.2.1 Phase I Activities . . . . . . . . . . . . . . . . . . . . . . . . 29

3.2.1.1 CAS 03-04-01, Area 3 Change House Septic System . . . . . 30

3.2.1.2 CASs 03-09-01, 03-09-03, 03-09-04, 03-09-05, Mud Pits . . . 32

3.2.1.3 CAS 20-16-01, Landfill and CAS 20-22-21, Drum(s) . . . . 34

3.2.2 Phase II Activities . . . . . . . . . . . . . . . . 35

3.2.2.1 CAS 03-04-01, Area 3 Change House Septic System . . . . . 36

3.2.2.2 CASs 03-09-01, 03-09-03, 03-09-04, and 03-09-05,

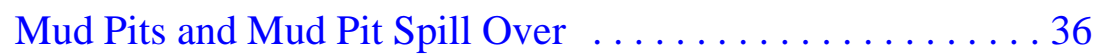

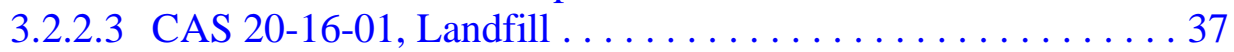

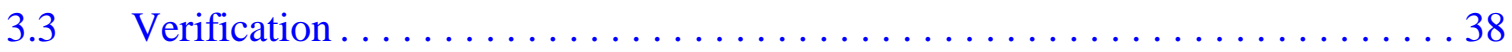

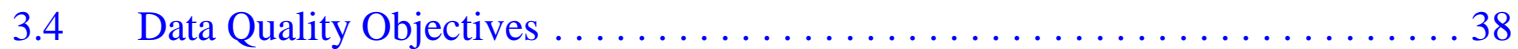




\section{Table of Contents (Continued)}

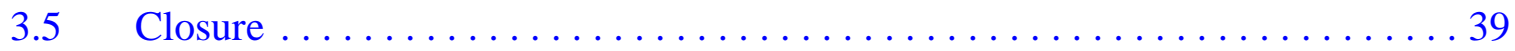

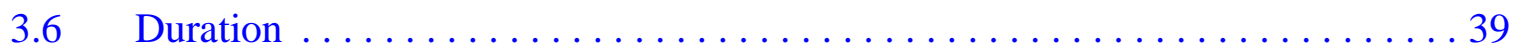

$4.0 \quad$ Reports and Records Availability ......................... 40

$5.0 \quad$ Waste Management. . . . . . . . . . . . . . . . . . . . . . 41

$5.1 \quad$ Waste Minimization . . . . . . . . . . . . . . . . . . . . . 41

5.2 Potential Waste Streams . . . . . . . . . . . . . . . . . . . . . 42

5.3 Management of Remediation and Investigation-Derived Waste . . . . . . . . 42

5.3.1 Nonhazardous Waste (Solid/Sanitary) . . . . . . . . . . . . . 43

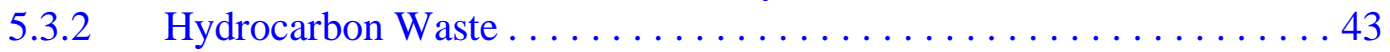

$5.3 .3 \quad$ Hazardous Waste . . . . . . . . . . . . . . . . . 44

5.3.4 Low-Level Radioactive Waste. . . . . . . . . . . . . . . . . . . . . . 45

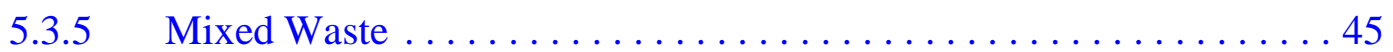

5.4 Analysis Required for the Disposal of IDW $\ldots \ldots \ldots \ldots \ldots \ldots \ldots \ldots$

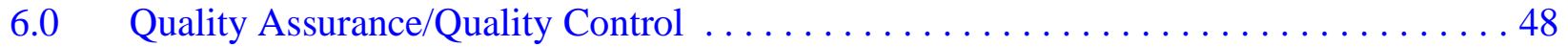

6.1 Quality Control Field Sampling Activities . . . . . . . . . . . . . . . 48

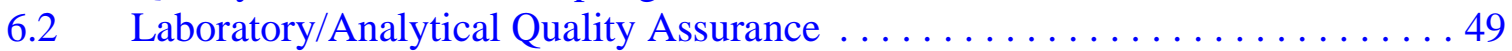

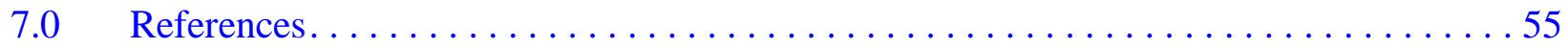

\section{Appendix A - Data Quality Objectives Worksheets}

A.1.0 DQO Overview . . . . . . . . . . . . . . . . . .

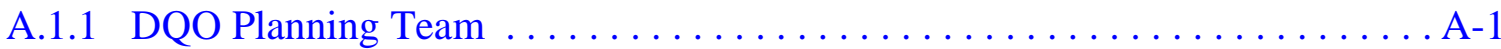

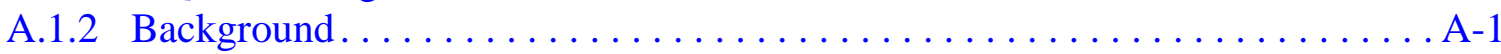

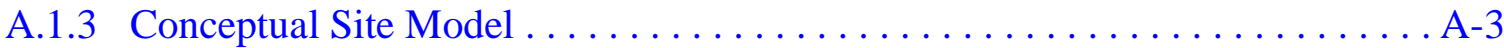

A.1.3.1 CSM for Mud Pits and Landfill . . . . . . . . . . . . . . A-3

A.1.3.2 Septic System CSM . . . . . . . . . . . . . A

A.2.0 Phase I DQOs . . . . . . . . . . . . . . . . . . . . . . . A-11

A.2.1 Step 1, State the Problem . . . . . . . . . . . . . . . . . . . A-11

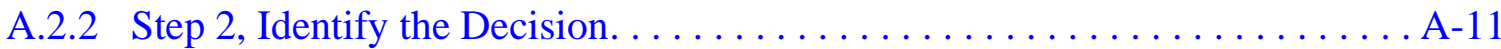

A.2.2.1 Alternative Actions to the Decision. . . . . . . . . . . . . . A-11

A.2.3 Step 3, Identify the Inputs to the Decision . . . . . . . . . . . . . . . A-11

A.2.3.1 Determine the Basis for Preliminary Action Levels . . . . . . . . . . A-15

A.2.3.2 Potential Sampling Techniques and Appropriate

Analytical Methods ......................... A-15

A.2.4 Step 4, Define the Boundaries of the Study . . . . . . . . . . . . . A-16 


\section{Table of Contents (Continued)}

A.2.4.1 Define the Target Population. . . . . . . . . . . . . . . . . A-16

A.2.4.2 Determine the Spatial and Temporal Boundaries . . . . . . . . . . . A-16

A.2.4.3 Identify Practical Constraints. . . . . . . . . . . . . . . . . . A-17

A.2.4.4 Define the Scale of Decision Making . . . . . . . . . . . . . . . A-17

A.2.5 Step 5, Develop a Decision Rule . . . . . . . . . . . . . . . . A-18

A.2.5.1 Specify the Population Parameter . . . . . . . . . . . . . A-18

A.2.5.2 Choose an Action Level. . . . . . . . . . . . . . . . . . A-18

A.2.5.3 Measurement and Analysis Methods................. A-18

A.2.5.4 Decision Rule. . . . . . . . . . . . . . . . . . . A-18

A.2.6 Step 6, Specify Tolerable Limits on Decision Errors . . . . . . . . . . . . . . A-18

A.2.6.1 False Rejection Decision Error . . . . . . . . . . . . . . . A-19

A.2.6.2 False Acceptance Decision Error. . . . . . . . . . . . . . . . . . . A-19

A.2.6.3 Quality Assurance/Quality Control . . . . . . . . . . . . . . . . . . A-20

A.2.7 Step 7, Optimize the Design for Obtaining Data . . . . . . . . . . . . A-20

A.2.7.1 Phase I . . . . . . . . . . . . . . . . . . . . A-20

A.2.7.2 CAS 03-04-01, Area 3 Change House Septic System . . . . . . . . . . A-21

A.2.7.3 CASs 03-09-01, 03-09-03, 03-09-04, and 03-09-05, Mud Pits and Mud Pit Spill Over. . . . . . . . . . . . A-24

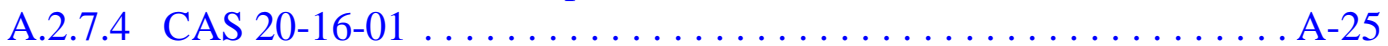

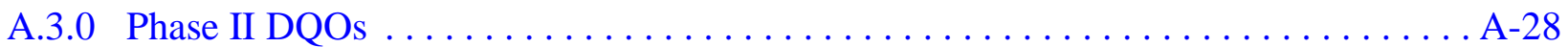

A.3.1 Step 1, State the Problem . . . . . . . . . . . . . . . . . . . A-28

A.3.2 Step 2, Identify the Decision. . . . . . . . . . . . . . . . A-28

A.3.2.1 Alternative Actions to the Decision. . . . . . . . . . . . . A-28

A.3.3 Step 3, Identify the Inputs to the Decision . . . . . . . . . . . . . . . A -28

A.3.3.1 Choose the Basis for Preliminary Action Levels. . . . . . . . . . . . . . . A-29

A.3.3.2 Potential Sampling Techniques and Appropriate

Analytical Methods . . . . . . . . . . . . . . . . . . . . A-29

A.3.4 Step 4, Define the Boundaries of the Study . . . . . . . . . . . . . . A-32

A.3.4.1 Define the Target Population................... A-32

A.3.4.2 Determine the Spatial and Temporal Boundaries . . . . . . . . . . A-32

A.3.4.3 Identify Practical Constraints. . . . . . . . . . . . . A-33

A.3.4.4 Define the Scale of Decision Making . . . . . . . . . . . . . . . A-33

A.3.5 Step 5, Develop a Decision Rule . . . . . . . . . . . . . . . . . . . A-34

A.3.5.1 Specify the Population Parameter . . . . . . . . . . . . . . . . . A-34

A.3.5.2 Choose an Action Level. . . . . . . . . . . . . . . . . A-34

A.3.5.3 Measurement and Analysis Methods................. A-34

A.3.5.4 Decision Rule. . . . . . . . . . . . . . . . . . . . . . . . . A A-34

A.3.6 Step 6, Specify Tolerable Limits on Decision Errors . . . . . . . . . . . . . . A-35 


\section{Table of Contents (Continued)}

A.3.6.1 False Rejection Decision Error . . . . . . . . . . . . . A-35

A.3.6.2 False Acceptance Decision Error. . . . . . . . . . . . . . A-35

A.3.6.3 Quality Assurance/Quality Control . . . . . . . . . . . . . . . A-36

A.3.7 Step 7, Optimize the Design for Obtaining Data . . . . . . . . . . A-36

A.3.7.1 Phase II . . . . . . . . . . . . . . . . . . . A-36

A.3.7.2 CAS 03-04-01, Area 3 Change House Septic System . . . . . . . . . . A-36

A.3.7.3 CASs 03-09-01, 03-09-03, 03-09-04, and 03-09-05,

Mud Pits and Mud Pit Spill Over. . . . . . . . . . . . . A-37

A.3.8 CAS 20-16-01, Landfill . . . . . . . . . . . . . . . . . A-39

A.4.0 References...................................... A-40

Attachment 1 - CAU 356 Constituents Used in Drilling Mud . . . . . . . . . . . A-45

\section{Appendix B - Project Organization}

B.1.0 Project Organization $\ldots \ldots \ldots \ldots \ldots \ldots \ldots \ldots \ldots \ldots \ldots \ldots \ldots \ldots \ldots \ldots \ldots \ldots \ldots$

\section{Appendix C - NDEP Comment Responses}




\section{List of Figures}

Number

1-1 Nevada Test Site, Nye County, NV. . . . . . . . . . . . . . . . 2

1-2 CAU 356 Closure Decision Process $\ldots \ldots \ldots \ldots \ldots \ldots \ldots \ldots \ldots \ldots$

2-1 Overall View of Return Mud Pit............................ 7

2-2 Overall View of Suction Mud Pit .......................... 7

2-3 Overall View of Landfill ................................... 13

2-4 Manhole South of Septic Tank ............................. 15

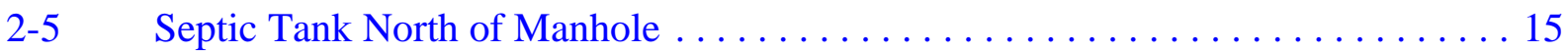

2-6 CAU 356, CAS 03-09-01 . . . . . . . . . . . . . . . . . . . . . . . . . . . 17

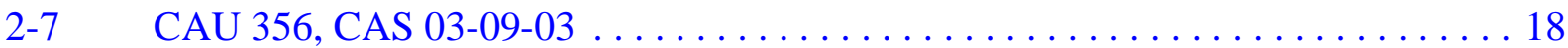

2-8 CAU 356, CAS 03-09-04 ................................... 19

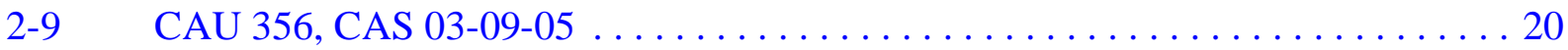

2-10 CAU 356, CAS 20-16-01 and CAS 20-22-21 .................. 21

2-11 Area 3 Change House Septic System ....................... 22

A.1-1 Conceptual Site Model for Mud Pits ........................ A-4

A.1-2 Conceptual Site Model for Mud Disposal Landfill................ A-5

A.1-3 Conceptual Site Model for Septic System. . . . . . . . . . . . . . . . . . A-8

A.2-1 Leachfield Potential Sample Locations....................... A-23

A.2-2 Mud Pit Phase I Potential Sample Locations . . . . . . . . . . . . . . . . . . . . . A-26

A.3-1 Preliminary Phase II Sampling Strategies .................... A-38 


\section{List of Tables}

Number

Title

Page

5-1 Waste Management Regulations and Requirements . . . . . . . . 43

5-2 Analysis Required for the Disposal of IDW . . . . . . . . . . . 47

6-1 Laboratory/Analytical Data Quality Indicators $\ldots \ldots \ldots \ldots \ldots \ldots$

6-2 Laboratory Chemical, Toxicity Characteristic Leaching Procedure, and Radiochemistry Analytical Requirements for Industrial Sites . . . . . . . . . . 51

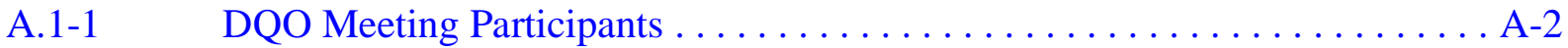

A.2-1 Identified Information/Data Needs to Resolve Decision . . . . . . . . . . . . A-12

A.3-1 Identified Information/Data Needs to Resolve Decision . . . . . . . . . A A-30

ATT. 1-1 Constituents Used in Drilling Mud. . . . . . . . . . . . . . . . . . . A-46 


\section{List of Acronyms and Abbreviations}

bgs Below ground surface

BN Bechtel Nevada

CADD Corrective Action Decision Document

CAIP Corrective Action Investigation Plan

CAS Corrective Action Site

CAU Corrective Action Unit

CFR Code of Federal Regulations

CLP Contract Laboratory Program

COCs Contaminant(s) of concern

COPC Contaminant(s) of potential concern

CSM Conceptual site model

DOE U.S. Department of Energy

DOT U.S. Department of Transportation

DQI Data quality indicators

DQO Data quality objective

DRI Desert Research Institute

EPA U.S. Environmental Protection Agency

ERD Environmental Restoration Division

FFACO Federal Facility Agreement and Consent Order

FSL Field-screening level

FSR Field-screening results

$\mathrm{ft} \quad$ Foot (feet)

GPR Ground-penetrating radar

HASP Health and Safety Plan

HDPE High-density polyethylene

HWAA Hazardous waste accumulation area 


\section{List of Acronyms and Abbreviations (Continued)}

\begin{tabular}{|c|c|}
\hline IDW & Investigation-derived waste \\
\hline in. & $\operatorname{Inch}(\mathrm{es})$ \\
\hline ISMS & Integrated Safety Management System \\
\hline ITLV & IT Corporation, Las Vegas Office \\
\hline LLW & Low-level radioactive waste \\
\hline $\mathrm{mg} / \mathrm{kg}$ & Milligram(s) per kilogram \\
\hline $\mathrm{mg} / \mathrm{L}$ & Milligram(s) per liter \\
\hline $\mathrm{mi}$ & Mile(s) \\
\hline MS/MSD & Matrix spike/matrix spike duplicate \\
\hline NAC & Nevada Administrative Code \\
\hline NDEP & Nevada Division of Environmental Protection \\
\hline NTS & Nevada Test Site \\
\hline NTSWAC & Nevada Test Site Waste Acceptance Criteria \\
\hline PAL & Preliminary action level \\
\hline PCB & Polychlorinated biphenyls \\
\hline $\mathrm{pCi} / \mathrm{g}$ & Picocurie(s) per gram \\
\hline $\mathrm{pCi} / \mathrm{L}$ & Picocurie(s) per liter \\
\hline PPE & Personal protective equipment \\
\hline ppm & Part(s) per million \\
\hline PRG & Preliminary remediation goal \\
\hline QA & Quality assurance \\
\hline QAPP & Quality Assurance Project Plan \\
\hline QC & Quality control \\
\hline $\mathrm{RCA}$ & Radioactive Controlled Area \\
\hline RCRA & Resource Conservation and Recovery Act \\
\hline REECo & Reynolds Electrical \& Engineering Co., Inc. \\
\hline
\end{tabular}




\section{List of Acronyms and Abbreviations (Continued)}

RMA Radioactive Materials Area

RPD Relative percent difference

RWMS Radioactive Waste Management Site

SAA Satellite Accumulation Area

SAFER Streamlined Approach for Environmental Restoration

SD Standard deviation

SSHASP Site-specific health and safety plan

SSL Soil screening level

SVOC Semivolatile organic compound(s)

TCLP Toxicity Characteristic Leaching Procedure

TPH Total petroleum hydrocarbon(s)

UVF Ultraviolet fluorescence

VOC Volatile organic compound

$\mu \mathrm{Ci} / \mathrm{ml} \quad$ Microcurie(s) per mililiter

$\mu \mathrm{g} / \mathrm{kg} \quad$ Microgram(s) per kilogram

$\mu \mathrm{g} / \mathrm{L} \quad$ Microgram(s) per liter

$\% \mathrm{R} \quad$ Percent Recovery 


\section{Executive Summary}

This Streamlined Approach for Environmental Restoration (SAFER) Plan addresses characterization and closure for Corrective Action Unit (CAU) 356, Mud Pits and Disposal Sites, identified in the Federal Facility Agreement and Consent Order. Corrective Action Unit 356 consists of the following Corrective Action Sites (CASs):

- CAS 03-04-01, Area 3 Change House Septic System

- CAS 03-09-01, Mud Pit Spill Over

- CAS 03-09-03, Mud Pit

- CAS 03-09-04, Mud Pit

- CAS 03-09-05, Mud Pit

- CAS 20-16-01, Landfill

- CAS 20-22-21, Drums

This plan provides the methodology for sampling potentially contaminated surface and subsurface soil to determine what activities, if any, are required for closure of each CAS. There is sufficient information and process knowledge from historical documentation and investigations of similar sites regarding the expected nature and extent of potential contaminants to recommend closure of CAU 356 using the SAFER process.

Corrective Action Site 03-04-01, Area 3 Change House Septic System, received sanitary sewage waste from approximately nine Area 3 Camp buildings and trailers from the 1960s until its abandonment some time in 1991. Based on engineering drawings, the septic system consists of one known leachfield, a potential abandoned leachfield, distribution box/manhole, septic tank, and underground piping. During the late 1980s an unpermitted lagoon formed above the leachfield area as a consequence of excessive flow and saturated conditions. A temporary remediation effort to evacuate the tank of fluids resulted in no additional percolation of effluent above the ground surface. However, it appears no other work has been performed to cap/close the septic tank and leachfield. Sanitary sewage waste is the primary contributor of effluent to this system. Additionally, industrial operations within other identified source buildings may have contributed potentially hazardous constituents. Potential corrective action alternatives for this CAS include closure-in-place, clean closure, and no further action or a combination of alternatives. 
The CAS 03-09-01, Mud Pit Spill Over, consists of a bermed return mud pit (130 feet [ft] by $120 \mathrm{ft}$ ), a smaller suction mud pit (125 ft by $15 \mathrm{ft}$ ), and a mud spill. The mud pits received drill cuttings, drilling fluid, and/or circulated drilling materials during preshot drilling activities. The apparent mud spill (with a footprint of approximately $100 \mathrm{ft}$ by $70 \mathrm{ft}$ ) occurred at the southern end of the suction mud pit, most likely the result of an overflow or a weir box failure. The two mud pits are associated with the preshot drilling activities of the U3ly emplacement hole drilled in 1984. The expected corrective action alternatives for this CAS include closure-in-place or no further action.

The CAS 03-09-03, Mud Pit, consists of a return mud pit (120 ft by $52 \mathrm{ft}$ ), and a smaller suction mud pit (60 ft by $20 \mathrm{ft})$. Both pits are bermed and tumbleweeds obscure the surface of each pit. These two mud pits received drill cuttings, drilling fluid, and/or circulated drilling materials during preshot drilling activities. Since both pits lie partially within the U3jv subsidence crater, it is assumed they are associated with the preshot drilling activities of the Rib Test emplacement hole drilled in 1976. The expected corrective action alternatives for this CAS include closure-in-place or no further action.

The CAS 03-09-04, Mud Pit, consists of one mud pit (105 ft by $35 \mathrm{ft}$ ) that received drill cuttings, drilling fluid, and/or circulated drilling materials during preshot drilling activities. The mud pit is bermed and tumbleweeds obscure the pit surface. The mud pit is associated with the preshot drilling activities of either the Tuloso weapons test emplacement hole or the exploratory hole, both drilled in 1971-1972 before the test. Soil originally excavated during construction of the mud pit forms a dirt mound on the southwest margin of the mud pit. The expected corrective action alternatives for this CAS include closure-in-place or no further action.

The CAS 03-09-05, Mud Pit, consists of one mud pit (225 ft by $150 \mathrm{ft}$ ) that received drill cuttings, drilling fluid, and/or circulated drilling materials during preshot drilling activities associated with the Bouschet weapons-related underground test. The emplacement hole was completed in 1979. It appears that this mud pit may have been utilized as an overflow pit to contain excess drilling fluids. The remains of a broken asphalt road runs through the northwest edge of the mud pit resulting in an accumulation of an asphalt pile about $110 \mathrm{ft}$ by $6 \mathrm{ft}$. Three sides of the mud pit are elevated about $10 \mathrm{ft}$ above the mud surface and encompass the pile of asphalt. The expected corrective action alternatives for this CAS include closure-in-place or no further action. The asphalt debris will be removed by housekeeping activities. 
The CAS 20-16-01, Landfill, was a formerly permitted construction landfill located within the U20b crater for disposal of uncontaminated excess drilling mud and fluids from drilling activities occurring in Area 20. Miscellaneous debris such as pipes, concrete, cables, drums, and a wooden structure are located within the crater boundaries as well. Historical records indicate disposals occurred from approximately 1988 to 1992-1993 after underground testing ended. The U20b crater was created in 1969 after the weapons-related Pipkin test. Although designated as a permitted landfill, formal closure activities of this landfill have not occurred. For this reason, the landfill will be investigated under the assumption that potentially hazardous and/or radioactive wastes may be present due to unauthorized disposal of waste materials. Several housekeeping activities will be performed at this CAS to remove miscellaneous debris. A corrective action alternative of closure in place or no further action is expected for this CAS.

Corrective Action Site 20-22-21, Drums, consists of two drums of unknown contents located within the boundary of CAS 20-16-01, Landfill. The drums are located at the bottom of the U20b crater near the mud. This housekeeping CAS was transferred from CAU 352 to CAU 356 to expedite remediation while performing other housekeeping activities at CAS 20-16-01, Landfill.

Historical information and process knowledge identified sources of potential contamination for the mud pits, mud disposal landfill, and septic system. Additives, such as polymers, chromium, and diesel, were typically included in drilling fluid mixtures to enhance the performance of the drilling equipment. Information indicates that some of these additives might contain Resource Conservation and Recovery Act or State of Nevada-regulated contaminants. Discharges from vehicles near the mud pits may have released fuels, motor oil, and hydraulic fluids into the effluent stream. Industrial operations in several source buildings to the septic system may have contributed constituents of concern in the form of lead cuttings, lead paint, cutting oils, degreasers/solvents, and liquid ammonia.

The Data Quality Objective process developed for this CAU identified data gaps that require additional data collection prior to implementing the preferred closure alternative for each CAS. A phased approach has been chosen to address the data collection activities. Phase I will determine if contaminants of potential concern (COPCs) are present in concentrations exceeding the preliminary action levels. If COPCs are found to be present above preliminary action levels, a Phase II investigation will be implemented to determine the extent of contamination and generate information 
to select a corrective action alternative. The following text summarizes the types of activities that will complete closure of CAU 356:

- Perform site preparation activities and collect preliminary data (i.e., configuration of leachfield).

- Collect environmental samples from designated populations (i.e., mud/soil cuttings) and submit for laboratory analysis to confirm or disprove assumptions regarding the nature and extent of contamination so that the appropriate corrective action alternative may be selected and implemented.

- If closure in place is the preferred closure alternative, the appropriate use restrictions will be implemented.

- If clean closure is the preferred closure alternative, the material to be remediated will be removed, disposed of as waste, and verification samples will be collected in remaining soil.

- Investigate upstream piping associated with the septic system using a combination of visual, video, and/or geophysical surveys. Collect sediment samples in the piping (if possible) and submit for laboratory analysis.

- Closure activities for the septic tank include pumping out the contents and sampling for waste determination; collecting and analyzing integrity soil samples at inlet and outlet ends of tank; removing the tank structure or leaving in place and backfilling according to Nevada Administrative Code regulations; and grouting any open access points.

- Housekeeping waste will be removed and photodocumented and, if required, soil verification sampling will be conducted for appropriate contaminants of concern.

- All completed closure activities for CAU 356 will be documented in a Closure Report.

Under the Federal Facility Agreement and Consent Order, the SAFER Plan will be submitted to the Nevada Division of Environmental Protection for approval. Field work will be conducted following approval of the plan. On completion of the field activities, a Closure Report will be prepared and submitted to the Nevada Division of Environmental Protection for review and approval. 


\subsection{Introduction}

This Streamlined Approach for Environmental Restoration (SAFER) Plan addresses the actions necessary for the closure of Corrective Action Unit (CAU) 356, Mud Pits and Disposal Sites, identified in the Federal Facility Agreement and Consent Order (FFACO) (1996). This CAU contains Corrective Action Sites (CASs) located within Area 3 and Area 20 of the Nevada Test Site (NTS). The NTS is approximately 65 miles (mi) northwest of Las Vegas, Nevada (Figure 1-1). The six CASs that comprise CAU 356 are as follows:

- CAS 03-04-01, Area 3 Change House Septic System

- CAS 03-09-01, Mud Pit Spill Over

- CAS 03-09-03, Mud Pit

- CAS 03-09-04, Mud Pit

- CAS 03-09-05, Mud Pit

- CAS 20-16-01, Landfill

- CAS 20-22-21, Drums

There is sufficient information and process knowledge from historical documentation and investigations of similar sites regarding the expected nature and extent of contaminants of potential concern (COPCs) to recommend closure of CAU 356 using the SAFER process (FFACO, 1996). The Data Quality Objectives (DQOs) developed for CAU 356 identified data gaps that require additional data collection prior to implementing the preferred closure alternative for each CAS. A phased approach has been chosen to address the data collection activities. Phase I will determine if COPCs are present in concentrations exceeding preliminary action levels (PALs). If COPCs are present above PALs, a Phase II investigation will be implemented to determine the extent of contamination to support the appropriate corrective action alternative to complete closure of the site.

\subsection{SAFER Process}

The SAFER process combines elements of the DQO process and the observational approach to help plan and conduct corrective actions. The DQOs are used to identify the problem and define the type and quality of data needed to complete the investigation phase of the process. The observational approach provides a framework for managing uncertainty and planning decision making. The purpose of the investigation in the SAFER process is to verify the adequacy of existing information to implement the corrective action. 


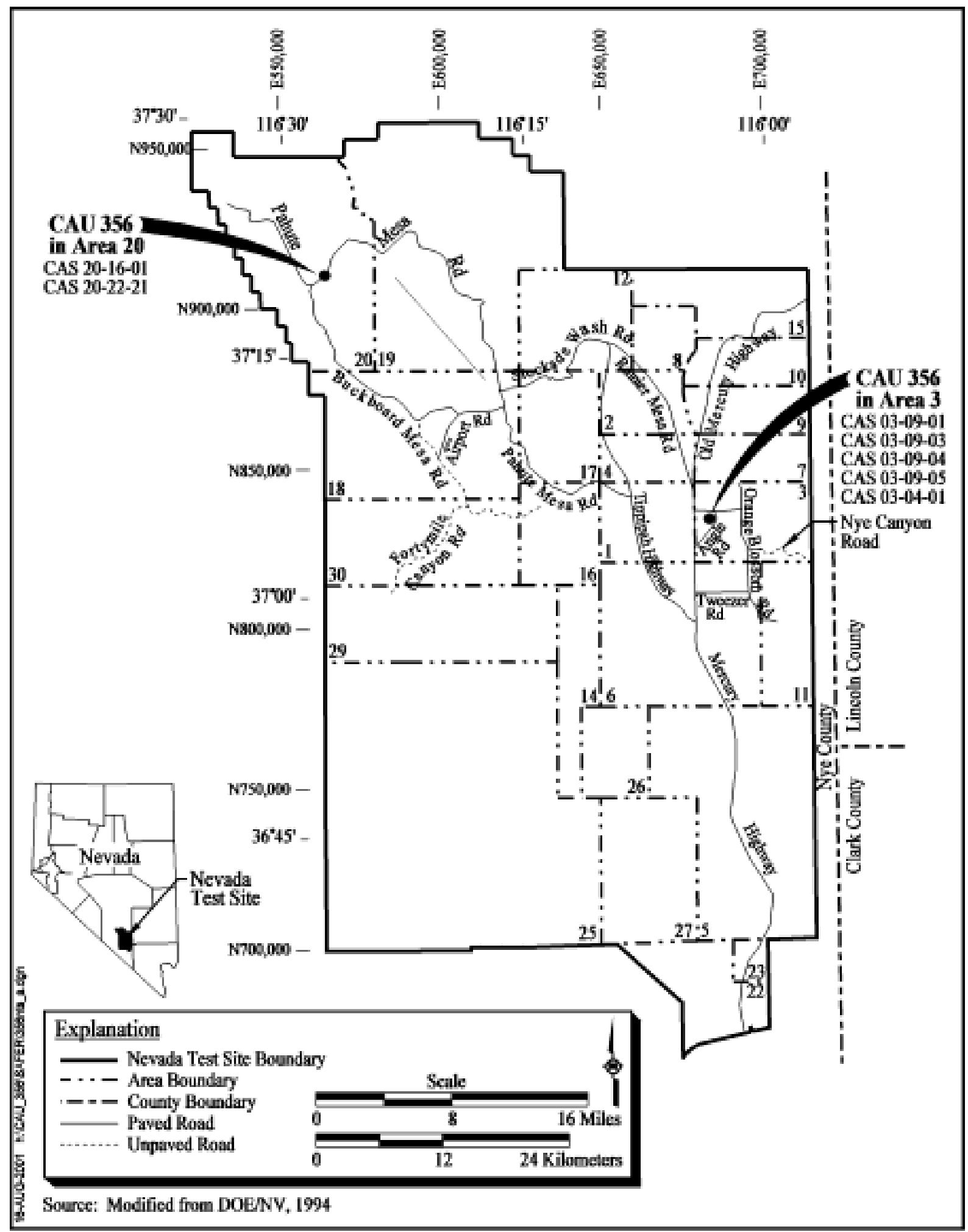

Figure 1-1

Nevada Test Site, Nye County, NV 
The SAFER concept recognizes that technical decisions may be made based on incomplete but sufficient information, as well as the experience of the decision-maker. Uncertainties are addressed through documented assumptions that are verified by sampling and analyses, data evaluation, on-site observations as planned activities progress, and developing any necessary contingency and monitoring plans. The remediation and closure may proceed simultaneously with site characterization as sufficient data are gathered to confirm or disprove the assumptions made in selecting the closure method. If at any time during site closure, new information is developed to indicate that the closure method should be revised, the closure activities will be redirected to more appropriately protect human health and the environment.

The decision process for closure of CAU 356 is summarized in Figure 1-2. This decision process starts with the Phase I investigation in which the appropriate target population(s) within each CAS (defined in the DQO process, Appendix A) is sampled. The process continues with a Phase II investigation, if the laboratory data indicate the need for additional characterization of the CAS. The process ends with closure of the site based on the laboratory analytical results of the environmental samples. Corrective action alternatives of closure-in-place and clean closure will be evaluated for each CAS with contaminants of concern (COCs).

\subsection{Summary of Corrective Actions}

The text below summarizes the types of activities that will complete closure of CAU 356. Additional details regarding these activities are given in Section 3.0 and Appendix A:

- Perform site preparation activities and collect biasing factor data (i.e., configuration of leachfield).

- Collect environmental samples from designated target populations (i.e., mud/soil cuttings above textural discontinuity) and submit for laboratory analyses to confirm or disprove presence of COCs and assumptions about the nature and extent of contamination.

- Investigate upstream piping associated with the septic system using a combination of visual, video, and/or geophysical surveys. Collect sediment samples in the piping (if possible) and submit for laboratory analyses.

- Determine if the corrective action is closure-in-place or clean closure for CASs with COCs.

- Close the septic tank under Nevada Administrative Code (NAC) regulations. 


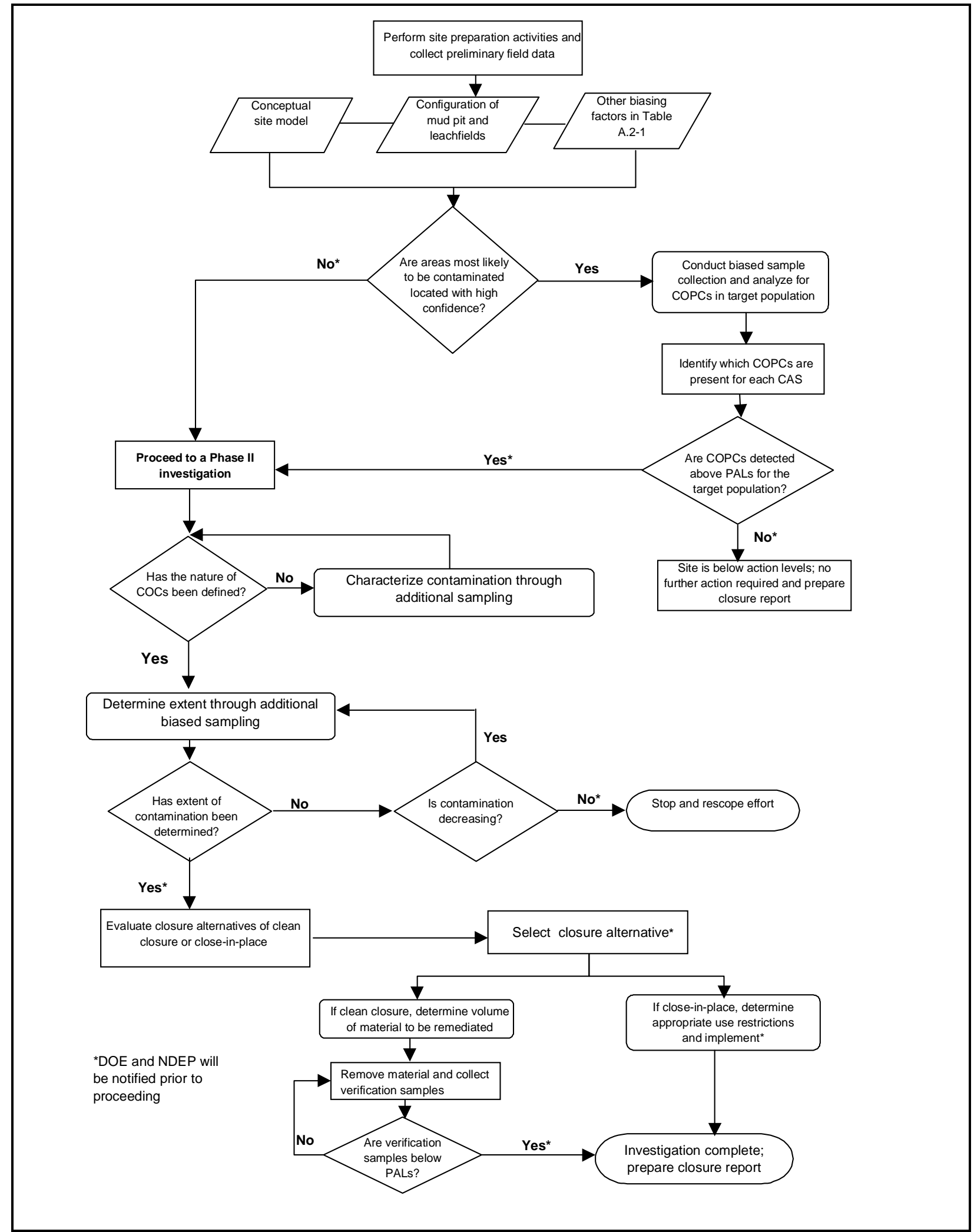

Figure 1-2

CAU 356 Closure Decision Process Excel Diagram 
- Perform housekeeping activities for debris at various CASs. Collect verification samples for any soil removal activities associated with either housekeeping and/or clean closure and submit for laboratory analyses for appropriate COCs.

\subsection{SAFER Work Plan Contents}

This SAFER Plan has been developed to support the proposed data collection activities and closure actives for CAU 356. The format of this Plan is as follows:

- Section 1.0 provides an introduction to this project and the SAFER process.

- Section 2.0 provides site locations and descriptions.

- Section 3.0 provides the field activities and closure objectives.

- Section 4.0 provides the reports and records to be generated during the investigation and closure activities.

- Section 5.0 discusses the waste management issues for the investigation and remediation.

- Section 6.0 discusses the project Quality Assurance and Quality Control requirements.

- Section 7.0 provides a list of project references.

- Appendix A provides the DQOs formulated for this CAU.

- Appendix B provides the Project Organization. 


\subsection{Unit Description}

This section presents the description of the CAU including history, location, process knowledge, and closure standards.

\subsection{History}

The following sections provide brief operational histories and descriptions of the CASs that comprise CAU 356.

\subsubsection{Mud Pits}

The mud pits in this CAU are by-products of drilling activities conducted at the NTS in support of the underground nuclear weapons testing. Drilling mud was typically used during drilling activities to both cool and lubricate the drill bit and suspend solids to assist in carrying drill cuttings back to the surface where they could be deposited in a nearby mud pit (e.g., return pit) (REECo, 1994; Witt, 2000a). It was also used to stabilize the wall of the drill hole to keep the hole from collapsing (Witt, 2000a).

During typical preshot drilling, two mud pits were utilized to provide water and to receive drill cuttings, drill fluid, and/or circulated drilling material (Butler, 2000; Wilkes, 2000a). These mud pits were referred to as the return pit and the suction pit. There were instances where the emplacement hole for a test would be drilled, but the test would not be performed. These abandoned holes were referred to as "nonshot holes," and are still considered preshot. The mud pits associated with CAU 356 are consistent with preshot or nonshot mud pits; however, several other craters usually exist within close proximity to these mud pits. It is unknown if other drilling activities utilized these mud pits. Figures 2-1 and 2-2 provide a view of both a return and a suction mud pit within this CAU.

The initial drilling mud was often transported to the drill site in Baker tanks. Fresh water would be initially stored in the suction pit, the smaller of the two pits, until it was injected in the drill hole along with the drilling mud. As the drilling proceeded, drilling mud and drill cuttings were brought up to the surface and discharged into the return pit via a blooey line. Heavy drill cuttings and other dense materials settled at the bottom of the return pit, which was sloped to a channel leading to the suction pit. After the dense materials settled, the remaining fluid flowed through the channel into the suction 


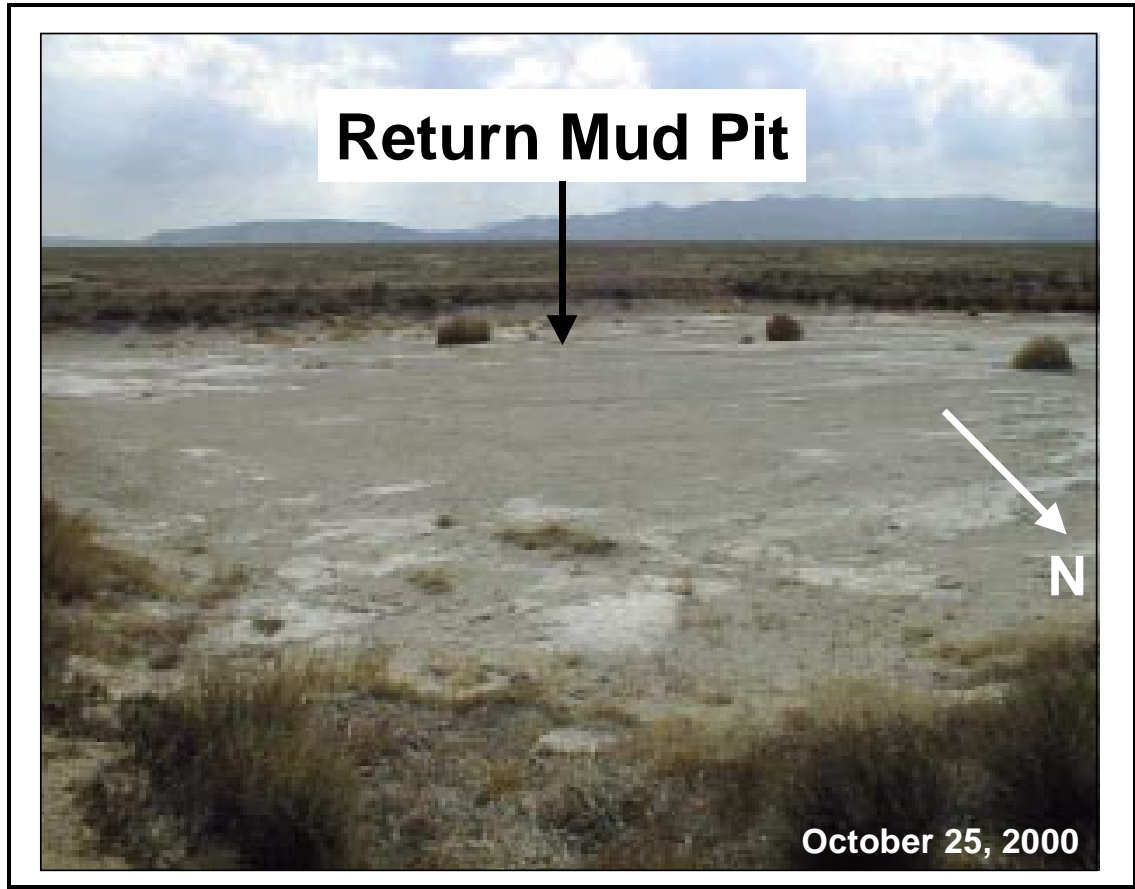

Figure 2-1

Overall View of Return Mud Pit

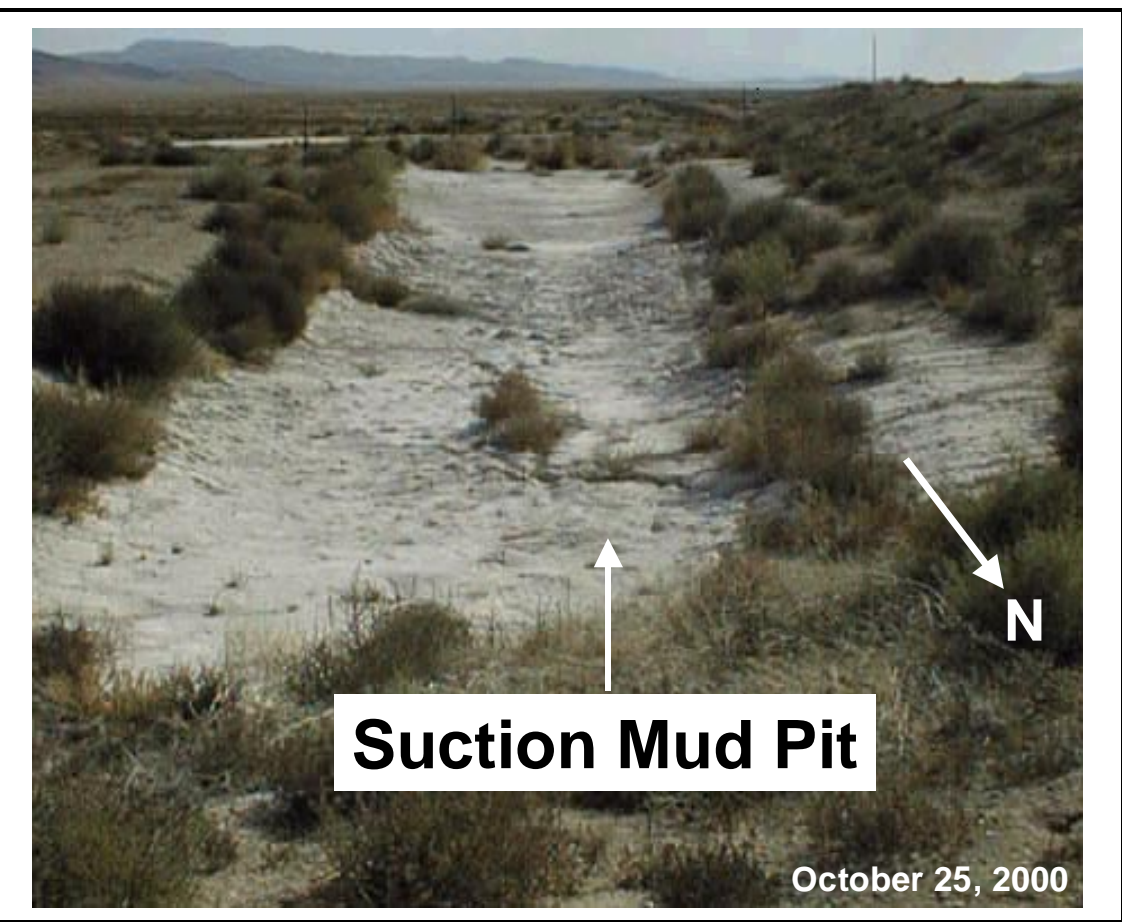

Figure 2-2

Overall View of Suction Mud Pit 
pit and was subsequently pumped out for reuse in the drilling operations. A weir box was used within the channel to regulate the flow of fluids between the two pits. This process continued recirculating the fluid until the drilling activities ceased (Wilkes, 2000a and 2000b; Witt, 2000a).

The main constituent of drilling mud was a powdered clay mixed with water. Bentonite and sepiolite were the two types of powdered clay used at the NTS (REECo, 1994). Additives were included in the fluid mixture to enhance the properties of the clay, subsequently enhancing the performance of the drilling equipment. Information indicates that some of these additives might contain Resource Conservation Recovery Act (RCRA) or State of Nevada-regulated contaminants (e.g., chrome often found in products such as Raykrome 400). However, it is unknown which additives were included in the drilling formulation for these particular operations.

Potential COPCs, in addition to known COPCs detected from site-specific sampling, were determined for mud pits from various sampling events at other NTS mud pits and an off-site location (Bordelois, 1998a,b,c; DOE/NV, 1999c,d). These include total petroleum hydrocarbons (TPH), RCRA metals (lead and chromium in particular), asbestos, paraformaldehyde, ethylenediamine, polychlorinated biphenyls, antifreeze, solvents, and various radionuclides (Adams, 2000; LANL, 1991; Rowe, 2001; Wilkes, 2000a; Witt, 2000a). A list of common mud additives compiled from historical sources and interviews is located in Attachment 1 of Appendix A.

Additional details regarding each mud pit CAS (e.g., associated emplacement holes and configuration) are discussed in the following sections.

\subsubsection{Mud Pit Spill Over, CAS 03-09-01}

The CAS 03-09-01, Mud Pit Spill Over, is located south of the U3ly emplacement hole in Area 3 of the NTS, and consists of two mud pits, a larger return pit and a smaller suction pit, and a mud spill. Drilling for the U3ly emplacement hole began in September 1984 and ceased in October 1984 (RSN, 1991); however, tests were never performed at this hole. It can be assumed that the mud pits were created around that time period. As-built drawings, dated September 1984, show plans for the two mud pits associated with the U3ly emplacement hole (H\&N, 1984). The site is currently listed in the FFACO as inactive and abandoned. 
The return pit is approximately $130 \mathrm{ft}$ by $120 \mathrm{ft}$ surrounded by a berm measuring 5 to $6 \mathrm{ft}$ above ground surface; little vegetation exists in the pit. Mud levels, as measured against the berm, vary from recharge area (highest) to the channel (lowest) resulting in a distinct slope. The return pit connects to the suction pit by a channel, which previously contained a weir box to control flow. The suction mud pit is approximately $125 \mathrm{ft}$ by $15 \mathrm{ft}$ and has little vegetation within it. The top edge of the suction pit is at ground level, approximately $5 \mathrm{ft}$ lower in elevation than the return pit, and appears to be about $3 \mathrm{ft}$ deep (Bull, 2001; IT, 2001).

The mud spill is located at the southern end of the suction pit, and is apparently the result of an overflow of the small pit or a weir box failure. The spill area measures approximately $100 \mathrm{ft} \times 70 \mathrm{ft}$, with a portion extending beyond a fenced crater boundary. The mud layer is easily visible and appears thin but somewhat continuous (Bull, 2001; IT, 2001).

Two samples were collected in August 1997, one sample collected from the channel to the elevated larger mud pit and another sample from the mud spill area (Bordelois, 1998a). Several COPCs including total VOCs, TPH, total RCRA metals, and various radionuclides were present at concentrations above detection limits but below action levels. Arsenic was the only COPC above action levels; however, the arsenic concentrations detected were not unusual for NTS soils and are considered representative of anticipated ambient conditions (Moore, 1999).

\subsubsection{Mud Pit, CAS 03-09-03}

CAS 03-09-03, Mud Pit, is located west of the U3jv crater in Area 3 of the NTS and consists of two mud pits, a larger return pit, and a smaller suction pit. These mud pits are located adjacent to the $\mathrm{U} 3 \mathrm{jv}$ crater, and are assumed to be associated with the nuclear-weapons test that formed this crater.

The emplacement hole for the nuclear-weapons test that created the U3jv crater was drilled in August 1976, with the Rib test conducted in December 1977. The mud pits would have been utilized during this time frame. The site is currently listed in the FFACO as inactive and abandoned (RSN, 1991; DOE/NV, 2000c).

The return pit is rectangular in shape, approximately $120 \mathrm{ft}$ by $52 \mathrm{ft}$. The return pit is surrounded by a small berm with little vegetation along the edge. The return pit connects to the suction pit by a channel, which previously contained a weir box to control flow. The suction pit is approximately 
$60 \mathrm{ft}$ by $20 \mathrm{ft}$ wide, and is located north of the return pit. The suction pit is surrounded by a berm with thick vegetation. Visible debris located within the suction pit consists of a large piece of corrugated pipe. The eastern ends of both pits and the channel are partially located within the subsidence crater U3jv and are completely filled with tumbleweeds, which makes viewing and access to the mud pits difficult. There is no evidence of mud outside of the mud pits (Bull, 2001).

One sample was collected from the bottom of the west end of the return mud pit in August 1997 (Bordelois, 1998b). Several COPCs including total VOCs, RCRA metals, and various radionuclides were present at concentrations above detection limits but below action levels. Arsenic was the only COPC identified above action levels; however, arsenic concentrations detected are not unusual for the NTS and are considered representative of anticipated ambient conditions (Moore, 1999).

\subsubsection{Mud Pit, CAS 03-09-04}

The CAS 03-09-04, Mud Pit, consists of a single pit located west of the potential crater area for U3gi in Area 3 at the NTS. The exploratory drill hole for U3gi is located between this mud pit and the U3gi emplacement hole. Generally, two pits are constructed for preshot drill holes; however, this site consists of a single pit. Additional drilling fluids may have been stored in a portable tank (Wilkes, 2000a). Another large mud pit exists on the northeast side of the U3gi potential crater area and is associated with the postshot location for U3gi and is not included in this CAS (H\&N, 1972).

The U3gi emplacement hole was drilled in August 1972, an exploratory hole was drilled in November 1972, and the Tuloso nuclear-weapons test associated with the U3gi crater was conducted in December 1972 (DOE/NV, 2000c; RSN, 1991). The mud pit for this CAS is believed to be the preshot and/or exploratory drill hole mud pit. The site is currently listed in the FFACO as inactive and abandoned. Postings are present stating "Caution, Potential Crater U3gi" and "Caution Contamination Area.”

The single mud pit measures approximately $105 \mathrm{ft}$ by $35 \mathrm{ft}$ and is filled with tumbleweeds obscuring the bottom. The sides are visibly bermed to about 2 to $3 \mathrm{ft}$ above the level of tumbleweeds. A piece of wood debris is present on the northeast side of the mud pit. Soil originally excavated during construction of the mud pit forms a dirt mound on the southwest margin of the mud pit. The potential crater fence bounds the eastern end of the mud pit (Bull, 2001; H\&N, 1972). 
One sample was collected from this mud pit in August 1997 (Bordelois, 1998c). The COPCs identified above detection limits included total SVOCs, RCRA metals, and various radionuclides. Arsenic was the only COPC identified above action levels; however, arsenic concentrations detected are not unusual for the NTS and are considered representative of anticipated ambient conditions (Moore, 1999).

\subsubsection{Mud Pit, CAS 03-09-05}

CAS 03-09-05, Mud Pit, consists of a single pit located northeast of the U3La crater within Area 3 of the NTS. Generally, two pits are constructed for preshot drill holes; however, this site consists of a single pit. Additional drilling fluids may have been stored in a portable tank. A second mud pit is visible within the crater boundaries but is addressed under a different CAU (Butler, 2000; Wilkes, 2000a).

Drilling for the U3La emplacement hole was completed in August 1979, and the corresponding nuclear-weapons test was performed in May 1982 (RSN, 1991; DOE/NV, 2000c). The mud pit may have been used during this time frame. The site is currently listed in the FFACO as inactive and abandoned.

The mud pit measures approximately $225 \mathrm{ft}$ x $150 \mathrm{ft}$ and is bermed along three sides. The southern side, located near the crater edge, is not bermed. The elevated sides of the pit are the result of the large excavation rather than engineered berms. The base of the pit is approximately $10 \mathrm{ft}$ beneath the ground surface and contains a thin layer of mud. Vegetation is sparse. Based on the appearance of the excavation and the minimum volume of mud within this pit, it may have been utilized as an overflow pit for the mud pit located within the crater (Bull, 2001).

Asphalt debris from an old road is located on the northwest area of the mud pit and fragments range in size up to several feet long and one-inch thick. The road appears to have originally run through the U3La crater area. The area of asphalt debris measures approximately $110 \mathrm{ft}$ by $6 \mathrm{ft}$ (Bull, 2001).

Two samples were collected from the mud pit in August 1997 (Forsgren, 1998). One sample was collected from the bottom of the mud pit and consisted of drilling mud, and the second sample was collected from under the asphalt and consisted of sandy silt and asphalt. COPCs identified above detection limits include VOCs, SVOCs, RCRA metals, gross alpha and gross beta, and various 
radionuclides (specifically potassium-40, lead-212, and lead-214). Arsenic was the only COPC identified that exceeded action levels; however, arsenic concentrations detected are not unusual for the NTS and are considered representative of anticipated ambient conditions (Moore, 1999).

\subsubsection{Landfill, CAS 20-16-01}

The CAS 20-16-01, Landfill, occupies the U20b crater and consists of disposed uncontaminated drilling mud from drilling activities conducted on the Pahute Mesa in Area 20 of the NTS. The site is located on the Pahute Mesa in Area 20. The U20b crater was created after an underground weaponsrelated test in October 1969 (DOE/NV, 2000c). Around 1987, the U20b crater was designated as a disposal area for excess, uncontaminated drilling mud resulting from drilling activities on Pahute Mesa. This location was chosen in lieu of transporting the mud from Pahute Mesa to the Area 3 Mud Disposal Crater (Rowe, 2000). Historical documentation identified the U20b crater as a permitted landfill; however, records of the permit have not been identified (Flangas, 1992; REECo, 1993). The U20b crater landfill was active until approximately 1992-1993 when underground testing ceased. A posted sign is still present indicating that the U20b crater area was utilized as an uncontaminated drilling fluid construction landfill (Bull, 2001).

The U20b crater measures approximately $400 \mathrm{ft}$ in diameter and $48 \mathrm{ft}$ deep based on engineering drawings, and was observed to contain mud in the crater bottom and miscellaneous debris around and within the perimeter. The depth of the mud could not be determined; however, the diameter appears to be about 75 to $100 \mathrm{ft}$. A berm is located on the west side of the crater and contains miscellaneous debris along its length. A discharge/access point is visible near the entrance of the crater where mud was dumped and allowed to flow to the crater bottom. This resulted in a small accumulation of mud near the top of the crater. Vegetation is present, except in the center of the crater where mud is present. Bedrock is exposed at the surface (Bull, 2001; IT, 2001). The photo in Figure 2-3 gives an overall view of the landfill, including debris and the access/discharge point.

Debris within the crater includes a reddish, wooden building, commonly known as a Brockhouse, situated at the northern margin of the crater inside the fence line. This building measures approximately $10 \mathrm{ft} \times 10 \mathrm{ft} \times 10 \mathrm{ft}$ and contains metal pipes and debris. Piping, several large cement slabs, cabling, and a few unlabeled 55-gallon drums lie near the mud at the base of crater. Plywood and steel piping are located outside the crater fence line (Bull, 2001). 


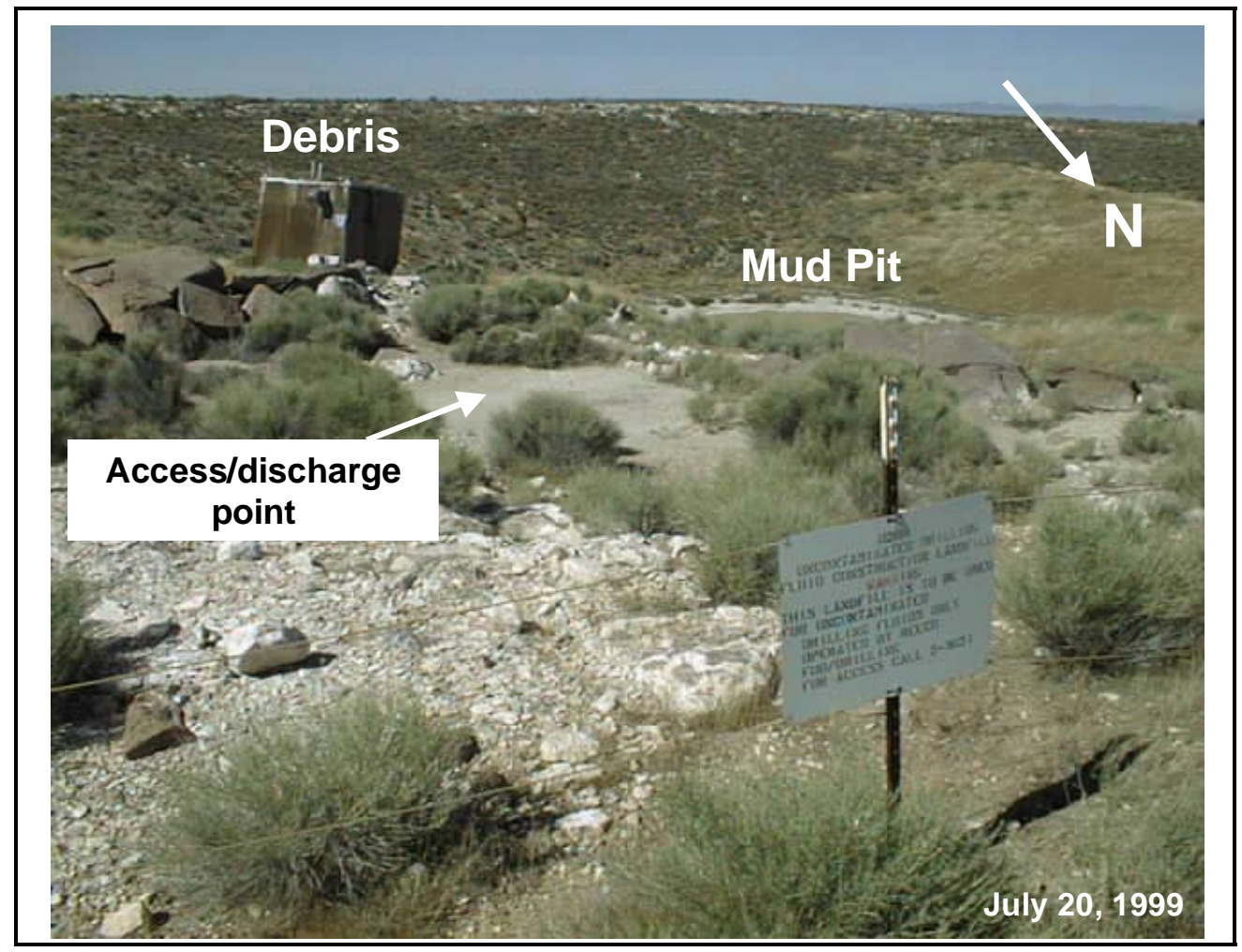

Figure 2-3

Overall View of Landfill

Available information indicates that mud disposed of at this site should be nonhazardous; however, monitoring controls in place for this site have not been identified. The COPCs for this site include contaminants identified from various mud pit analyses at the NTS and off-site locations, and from materials commonly used as components in earlier mud mixtures that were an inherent part of the drilling process (Bordelois, 1998a, b, and c; DOE/NV, 1999a). These assumed contaminants include TPH, RCRA metals, PCBs, antifreeze, paraformaldehyde, ethylenediamine, solvents, asbestos, and an array of radionuclides (Wilkes, 2000a, LANL, 1991; Rowe, 2001).

\subsubsection{Area 3 Change House Septic System}

The Area 3 Change House Septic System was initially constructed in the 1960s and received effluent from at least nine Area 3 Camp buildings and trailers until its abandonment in 1991 (Flangas, 1990; H\&N, 1962; H\&N, 1988). In 1989, an unpermitted lagoon formed above the leachfield as a consequence of excessive flow and saturated conditions. The overflow was caused by the addition of facilities connected to the septic system, in particular the Miners' Change House (Flangas, 1990; Haworth, 1990a and 2000). A new septic system was proposed but not implemented due to the 
impending relocation of the Area 3 Camp to Area 6. Temporary remediation of the existing system consisted of evacuating the septic tank of fluids to be treated at other NTS facilities until the camp was abandoned (Haworth, 1991). The temporary remediation efforts resulted in no additional percolation of effluent above the ground surface (Haworth, 1990b).

According to field observations and engineering drawings, the septic system consists of the following components:

- $\quad$ Leachfield - The leachfield measures approximately $100 \mathrm{ft}$ by $75 \mathrm{ft}$ and is surrounded by an orange fence. The area inside the fence is sunken inward and a sign on the northern end of the fence states "Health Hazard, Keep Out." A dense layer of dead tumbleweed is present inside and around the fence, obscuring the surface. Documentation was not identified indicating the configuration or extent of the leachfield lines (Bull, 2001; H\&N, 1992; REECo, 1990).

- $\quad$ Potential Leachfield - Engineering drawings suggest a leachfield may have previously existed directly south of the manhole and north of the fenced leachfield. The configuration of this leachfield is available. The manhole may have been utilized as a distribution chamber/box. This leachfield may have been abandoned when a break in the pipe located between the tank and the leachfield was observed in the 1970s (REECo, 1967).

- Distribution Box - The distribution box is not visible at the surface; however, engineering drawings place the box in the northwest corner of the fenced area. No other information is available (H\&N, 1988; REECo, 1990).

- Manhole - The manhole is located approximately $208 \mathrm{ft}$ north of the leachfield and is approximately 6-ft. deep. The manhole contains an inlet pipe and two parallel outlet pipes. One of the outlet pipes, directly in line with the inlet pipe, is capped and may have been connected to the older, potential leachfield. The uncapped line is oriented towards the fenced leachfield. Damp sediments were visible at the bottom (Bull, 2001; IT, 2001). Figure 2-4 shows the inside of the manhole.

- $\quad$ Septic Tank - The septic tank has a capacity of approximately 7,500 gallons and is not visible from the surface. Two wooden boxes cover separate openings into the septic tank. Pipe connections for liquid evacuation are present in each opening. There was also approximately $5.5 \mathrm{ft}$ of liquid and potentially sludge inside the septic tank. Visual observations suggest two chambers exist within the tank (H\&N, 1988; IT, 2001). Figure 2-5 is a photo of a pipe connection into one of the two tank openings.

- $\quad$ Piping - Piping associated with the septic system extends approximately 1,820 ft. Some source locations appear not to be capped based on field observations (H\&N, 1988). 


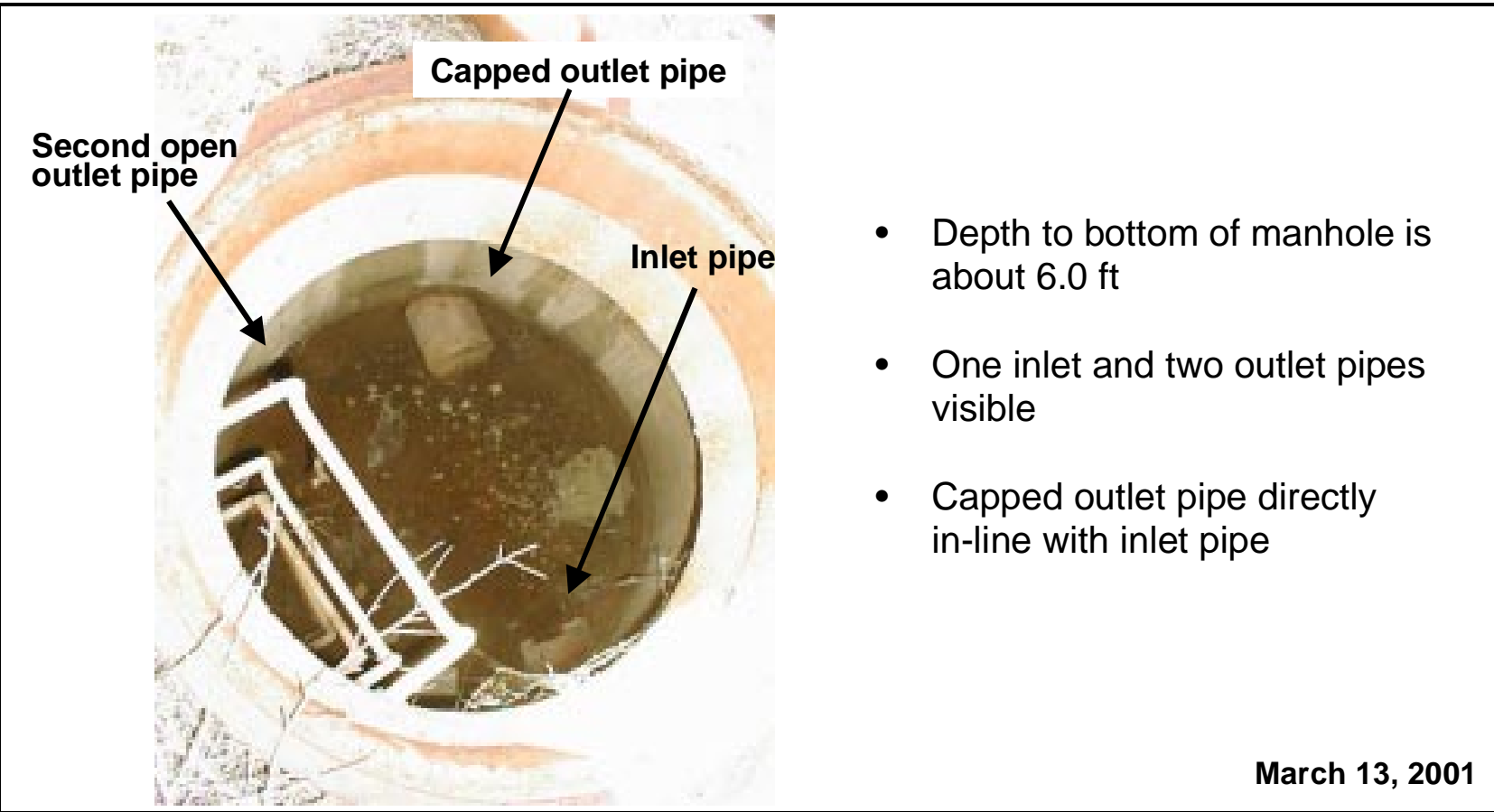

Figure 2-4

Manhole South of Septic Tank

- Septic tank can be accessed through two vertical, metal risers on both north and south ends

- Diameter of risers are about 12 in. for north end and 6.5 in. for south end

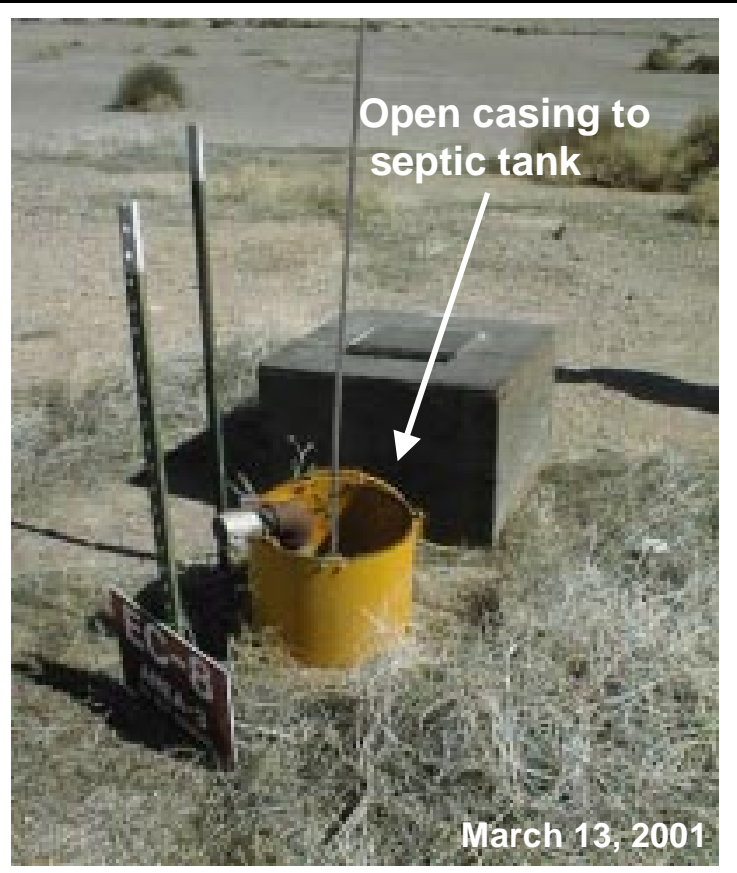

Figure 2-5

Septic Tank North of Manhole 
Although information exists identifying a pipe break that occurred in the 1970s, no further details have been identified (DOE/NV, 1995a). Documentation is not available to indicate if the break had been repaired or whether it resulted in the construction of a new leachfield. There were two outlet pipes exiting the manhole, one capped and one that is not capped (IT, 2001). The orientation of the uncapped outlet pipe suggests that it is connected to the existing leachfield. There is a potential for the capped outlet pipe to have been connected to a previous leachfield that was abandoned. This is supported by engineering drawings that indicate discrepancies on the distance between the septic tank and the existing leachfield (H\&N, 1988; REECo, 1967 and 1990). The septic tank location does not appear to have moved in relation to nearby buildings, but is observed as being at different distances from the leachfield. There is a potential that the currently fenced leachfield was constructed due to the break in the distribution pipe.

There have been no sampling efforts or analytical results identified for this site. Contaminants are based on process knowledge of source building activities and include sewage/biohazardous waste, lead, disinfectants, ammonia, steel, copper, aluminum, cutting oils, and solvents (e.g., MEK and 1,1,1-Trichloroethylene) (Haworth, 2000; Marshall, 2001b; Racine, 2001; Rogers, 2001; RSN, 1995). A list of known source buildings are labeled in Figure 2-11.

In 1995, the septic system was listed on the Preliminary Ranking and Prioritization for remediation; however, no documentation has been identified noting that remediation efforts took place after the Area 3 Camp was abandoned (DOE/NV, 1995b).

\subsection{Site Location and Description}

The CASs within CAU 356 are located within Area 3 and Area 20 of the NTS (see Figure 1-1). The four mud pit CASs are located in the northern portions of Area 3 and are shown in Figures 2-6 through 2-9 relative to nearby craters and other landmarks (e.g., roads). Figure 2-10 shows the mud disposal landfill within the U20b crater located on Pahute Mesa in Area 20 of the NTS. The Area 3 Change House Septic System is shown in Figure 2-11 with its associated source buildings and collection and distribution structures.

The description of work to be performed at each CAS is explained in detail within Section 3.0. 


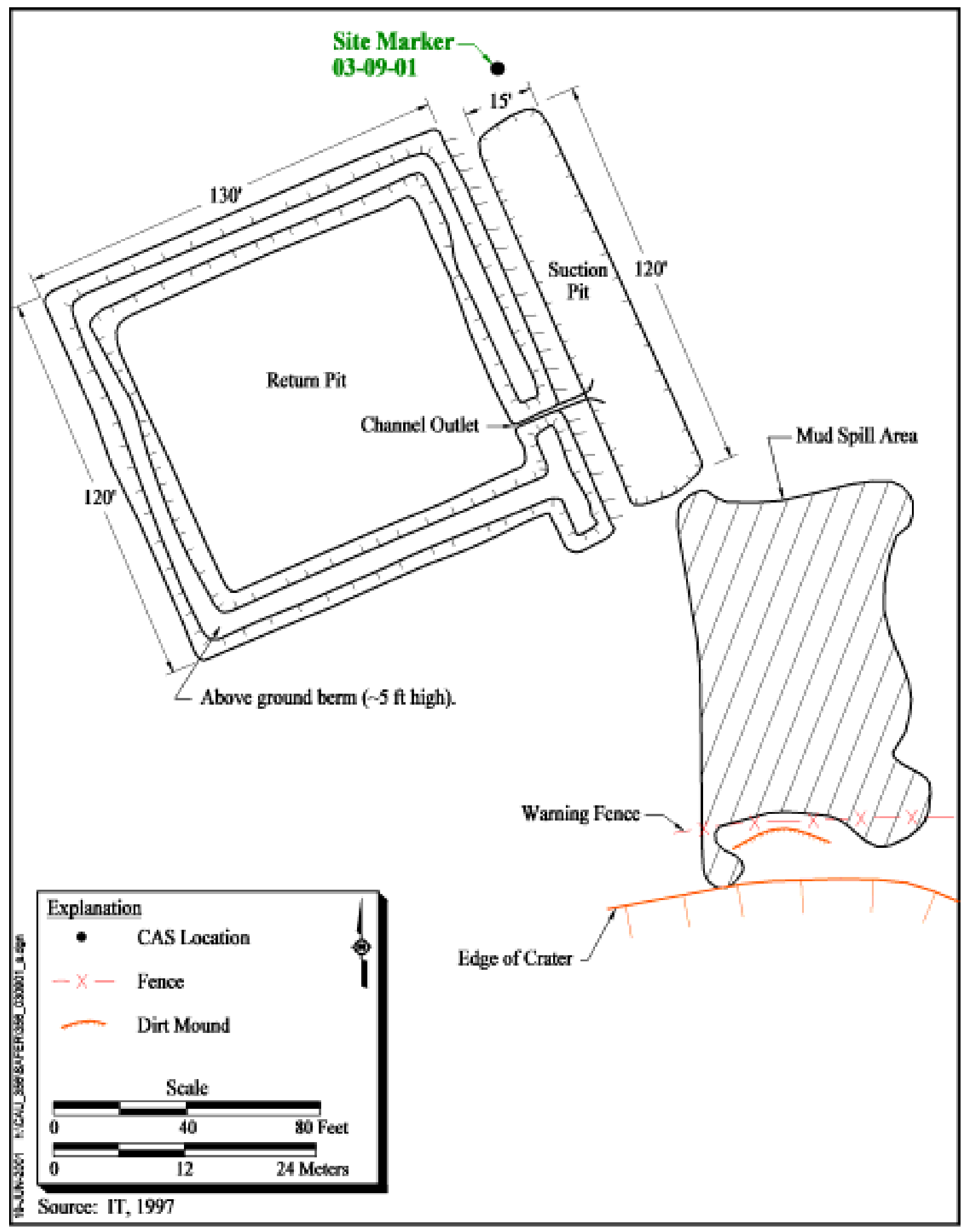

Figure 2-6

CAU 356, CAS 03-09-01 


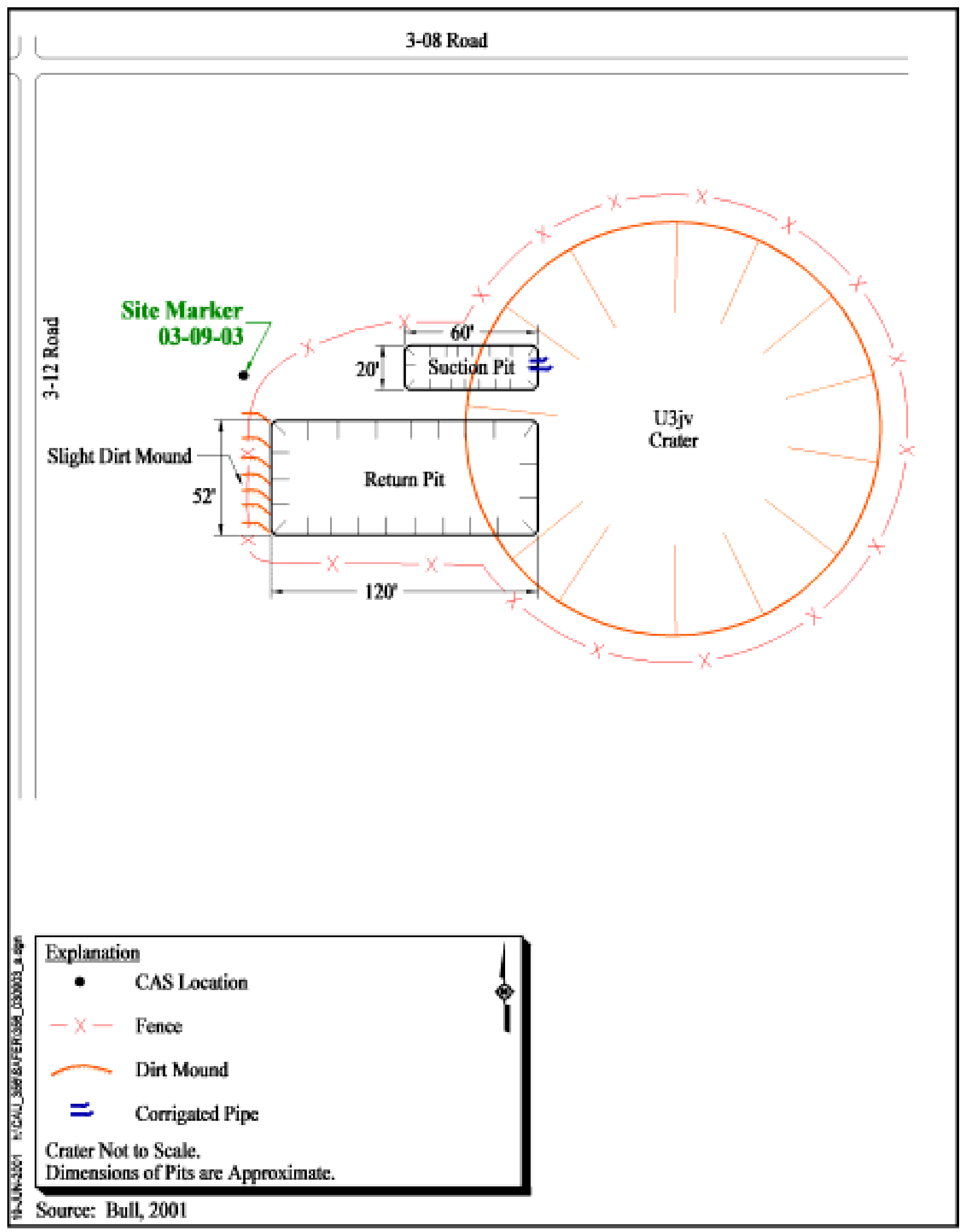

Figure 2-7

CAU 356, CAS 03-09-03 


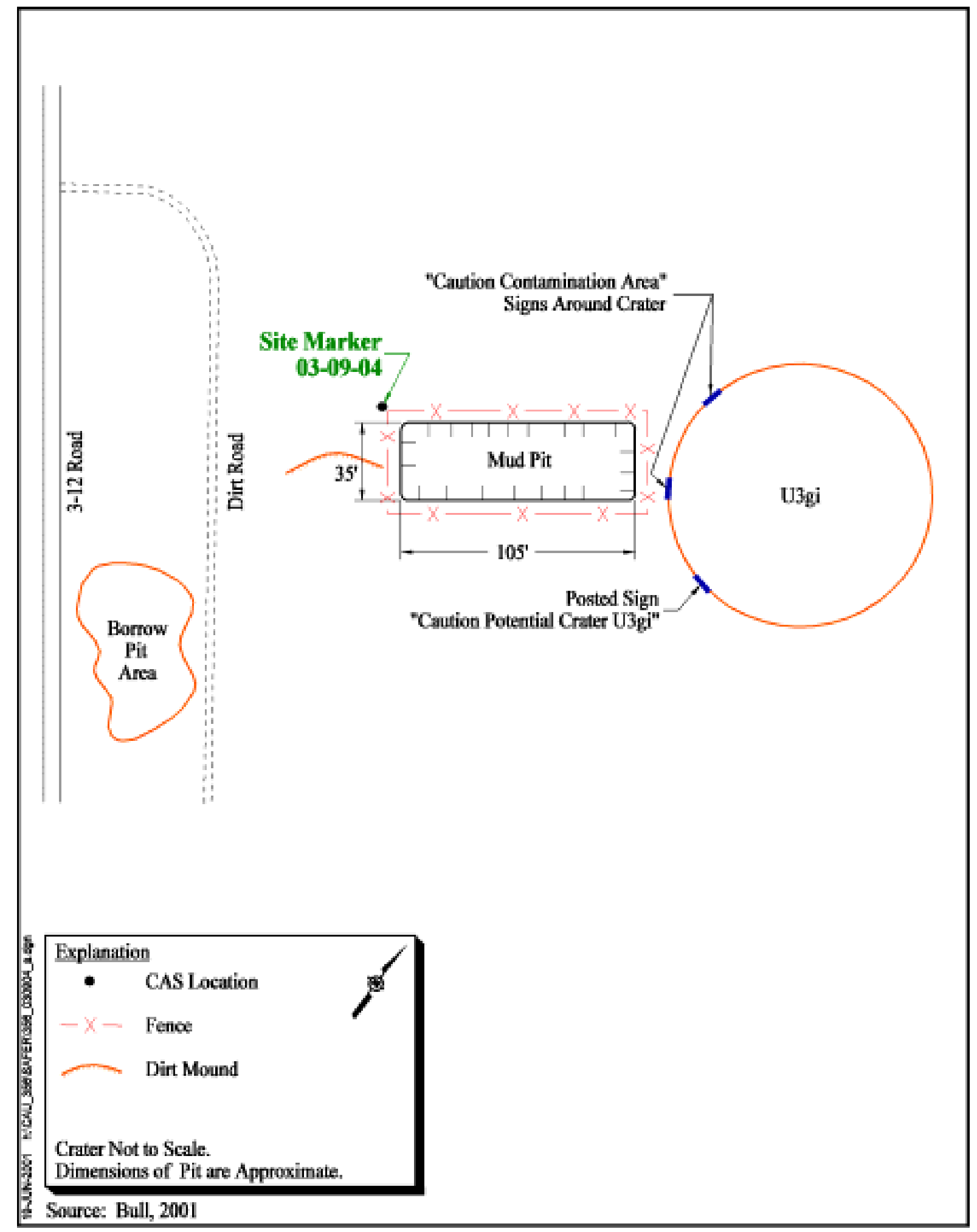

Figure 2-8

CAU 356, CAS 03-09-04 


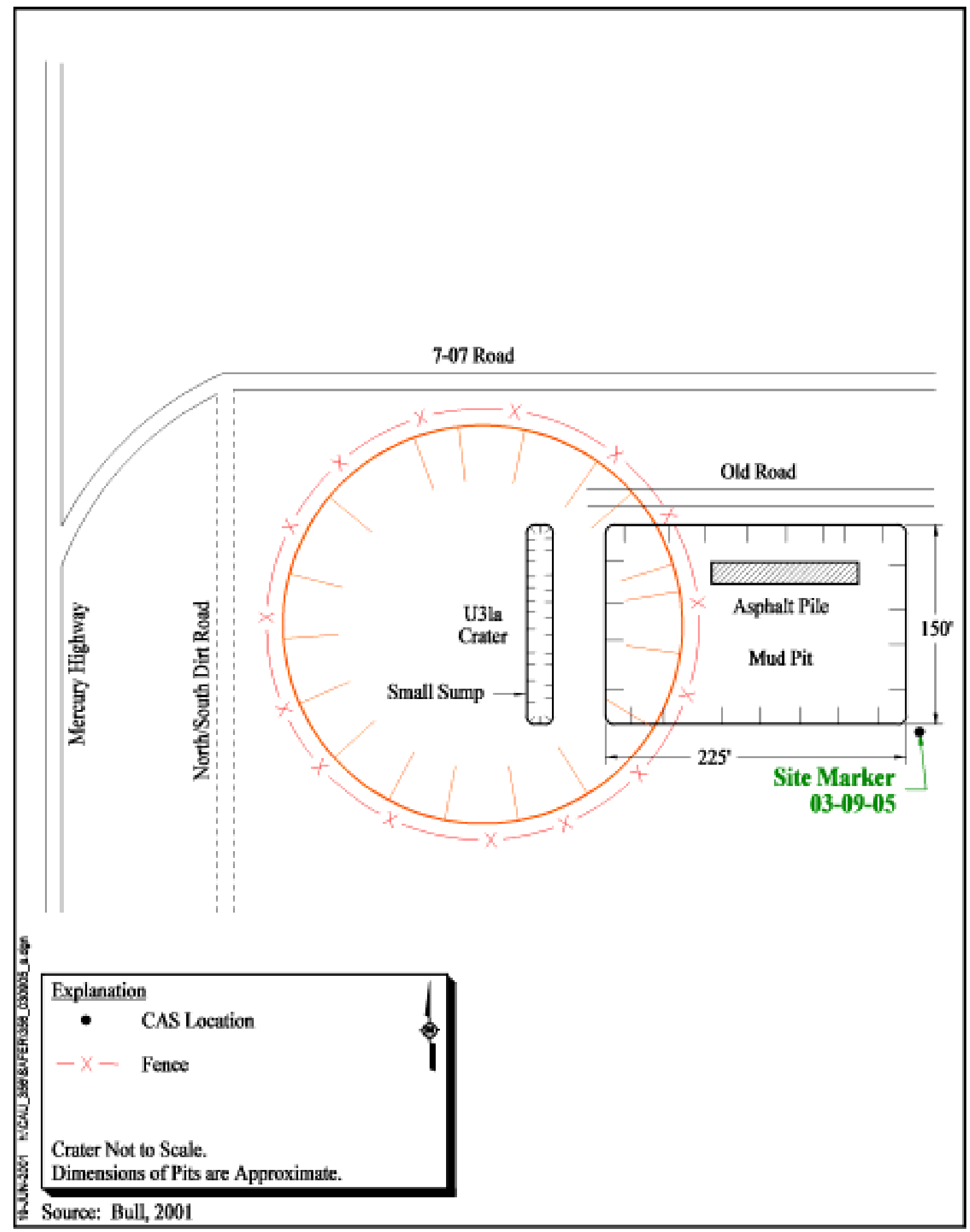

Figure 2-9

CAU 356, CAS 03-09-05 


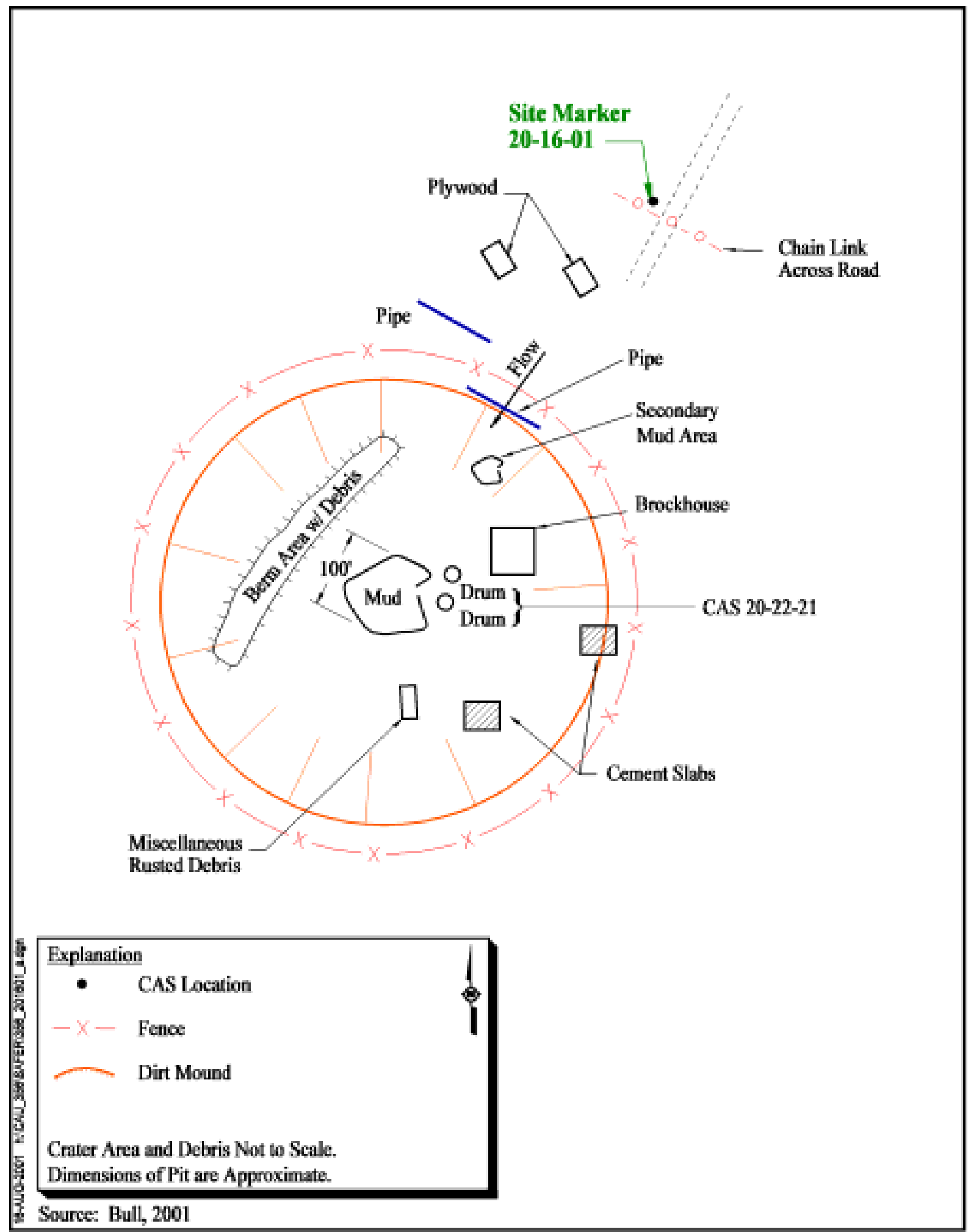

Figure 2-10

CAU 356, CAS 20-16-01 and CAS 20-22-21 


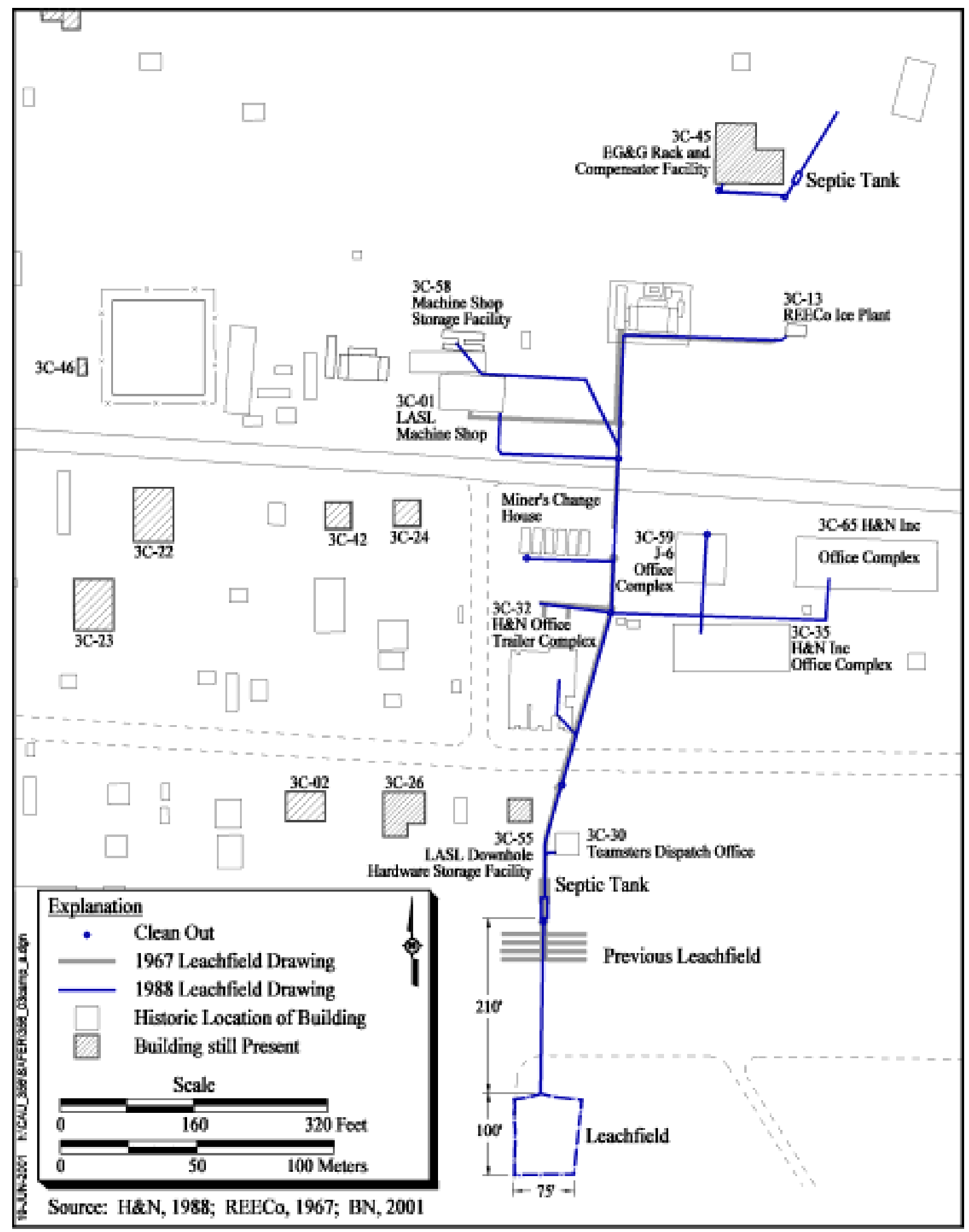

Figure 2-11

Area 3 Change House Septic System 


\subsection{Process Knowledge}

The conceptual site model (CSM) describes the most probable scenario for current conditions at each site and defines the assumptions that are the basis for this SAFER Plan. The assumptions are formulated from historical information and process knowledge.

Groundwater impacts from potentially migrating contaminants are not expected in Area 3 and Area 20 due to the depths to groundwater and limiting hydrologic drivers of low precipitation and high evaporation rates. Depth to groundwater in Area 3 generally ranges from approximately 1,500 feet (ft) below ground surface (bgs) at the south end to 1,885 ft bgs at the north end. Depth to groundwater in Area 20 generally ranges from 1,950 ft to 2,350 ft bgs (DRI, 1996; DRI, 1988).

Under Alternative 3 for future land use (DOE/NV, 1996a), Area 20 is located within the Nuclear Test Zone, while Area 3 is located within the Nuclear and High Explosive Zone. Both zones include compatible defense and nondefense research, development, and testing projects and activities. These land-use scenarios limit future uses to industrial activities; therefore, future residential uses are not considered. Potential exposure routes to site workers from COCs in septage and soils include oral ingestion, inhalation, or dermal contact (absorption) through the inadvertent disturbance of contaminated structures and/or soils.

\subsubsection{CSM for Mud Pits and Landfill}

Figures A.1-1 and A.1-2 in Appendix A show a generalized representation of the CSM constructed for the mud pits and the mud disposal landfill, respectively. The following text relates information and assumptions that were used in developing the CSM.

Disposal of used drilling mud and fluids are the primary source of COPCs in the mud pits and landfill. Additives, such as polymers, chromium, and diesel, were typically included in mud fluid mixtures to enhance the performance of the drilling equipment during NTS drilling activities (LANL, 1991; Wuellner, 1994; Witt, 2000a). Diesel within drilling muds is expected to be the primary COPC based on interviews (Wilkes, 2000a) and process knowledge gained from similar investigations of mud pits (e.g., Central Nevada Test Area [CNTA]). Recirculation processes within the mud pits enhance volatilization of VOCs, thereby reducing the potential concentrations of any volatile organic compounds (VOCs) that may be present. A secondary source of contaminants from random truck 
dumping activities and leaking vehicle discharge may have released fuels, grease, motor oil, and hydraulic fluids into the mud pit effluent stream (Wilkes, 2000b; Witt, 2000a). The volume of any particular contaminant in the drilling fluid effluent is unknown; however, random dumping of constituents is considered minimal in comparison to the discharge of drilling mud and cuttings.

Radionuclide contamination is not expected at these CASs based on historical information; however, the potential still exists based on process knowledge of the activities conducted in Area 3 and Area 20 of the NTS (i.e., underground nuclear testing). The primary radioisotopes that could be expected, if present, are cesium-137, tritium, and strontium-90 (Adams, 2000).

The following four areas represent the preferential locations within the mud pit system where contamination can be expected to be found, if present anywhere within the system:

- Near the surface and near the influent (recharge) location

- At the bottom of the pit near the influent location

- Near the surface at the lowest surface elevation

- At the lowest elevation of the pit bottom

These areas were selected based on distinguishing physical characteristics of the contaminants. For example, petroleum-based fuels in the mud slurry would tend to be found in higher concentrations near the surface of the mud pits. Other distinguishing characteristics of contaminants such as high or low solubility, high or low density, and large or small particle size can also be used to draw inferences on the locations within the mud pit system where higher concentrations could be expected.

In 1997, a limited sample collection activity was conducted at the four mud pit CASs. The samples were collected without regard to the characteristics listed above, so the analytical results are only useful for identifying potential COPCs. The analysis detected VOCs, semivolatile organic compounds (SVOCs), RCRA metals, TPH, and radionuclides. None of the results exceeded action levels or background (as defined in Section 3.5), except for arsenic which was above action levels but consistent with NTS background levels (Moore, 1999).

Mud and subsurface soils are the affected media within each mud pit and the mud disposal landfill. Infiltration of COPCs are assumed to be limited to less than $10 \mathrm{ft}$ vertically and $5 \mathrm{ft}$ laterally based on past investigations of several mud pits (e.g., CNTA) and process knowledge of mud characteristics. 
Even in the absence of an engineered physical barrier below the mud, vertical migration of contaminants should be minimal because bentonite clay has a low hydraulic conductivity and a high adsorption capacity that binds constituents and inhibits migration into subsurface soils. Bentonite clay is commonly used as a pond liner to prevent infiltration of water into underlying units. Based on these characteristics, contamination, if present, should be confined laterally to the historical and physical boundaries of each site such as the berms of each mud pit or the U20b crater. Lateral contamination of the mud spill at CAS 03-09-01 is not expected to extend past the edge of the visible mud layer. Vertical and lateral migration is also currently limited because the mud pits are dry and potential evaporation exceeds precipitation.

The densely welded volcanic tuff units that underlie the crater mud pit (see Figure A.1-1) tend to be highly fractured with increased transmissivity (USGS, 1970 and 1973). The underground nuclear test (i.e., Pipkin) conducted at U20b induced additional fracturing of these units and a surface crater. These densely welded tuffs provide preferential pathways to groundwater; however, there are factors that inhibit the migration of any COCs present in the mud to groundwater. The highly adsorptive nature of mud (i.e., bentonite) binds the contaminant and inhibits the migration of constituents as previously discussed in this CSM. Bentonite is also commonly used as natural pond liners to prevent infiltration and would create seals within fractures underlying the mud limiting infiltration of precipitation.

\subsubsection{Septic System CSM}

Figure A.1-3 in Appendix A shows a generalized representation of the CSM constructed for the septic system. The following text relates the information and assumptions that were used in developing the CSM.

This septic system was primarily used for sanitary waste from around 1962 to 1991 . The system was abandoned around 1991 (H\&N, 1962; Haworth, 1991); however, no historical data was identified to indicate that collection and/or distribution lines were capped to prevent unauthorized discharge. Recent site visits confirm several drains from contributing buildings appear open and accessible (IT, 2001).

Nine buildings and trailers were identified through historical documentation as contributing COPCs into the septic system effluent stream. The primary source of effluent was sanitary waste from 
restroom facilities located within these source buildings. Industrial activities within the Machine Shop and Storage facilities may have contributed potentially hazardous constituents in the form of lead cuttings, lead paint, cutting oils, degreasers, and solvents (H\&N, 1988; REECo, 1967; Marshall, 2001a and 2001b; Rogers, 2001). Liquid ammonia from blueprinting activities may also have been discharged into the effluent stream (RSN, 1995; Racine, 2001). Historical sampling results have not been identified for this CAS.

Radionuclide contamination is not expected at this CAS, based on historical information; however, the potential still exists, based on process knowledge of the activities conducted in Area 3 (i.e., underground nuclear testing).

The affected media are liquid and sludge/sediment within distribution structures, and surface and subsurface soils in proximity of the collection and distribution lines. Previous investigations of septic tanks at the NTS (REECo, 1995) found that, in general, COPCs were observed in septic tanks at higher concentrations than in leachfield soils. Within the leachfield, soil immediately beneath leachfield distribution lines are expected to show the highest concentration of COPCs (DOE/NV, 1998). This assumption holds for the abandoned leachfield; however, saturated conditions at the currently fenced leachfield may have allowed some soluble constituents and liquid to migrate to the surface. Additionally, a potential exists for the currently fenced leachfield to have a lagoon-type configuration instead of the typical leachfield configuration with a distribution box and distribution lines. A lagoon configuration with an outfall pipe changes the distribution of COPCs to directly beneath the discharge end of the outfall pipe and the bottom of the lagoon where contaminants would concentrate due to settling and infiltration/evaporation.

Saturated conditions within the currently fenced leachfield are known to have existed which contribute to a potential for lateral migration and/or overflow (Haworth, 1990a; Watson, 1990). Migration may extend up to $15 \mathrm{ft}$ beyond distal ends of distribution lines (or the bermed edge) of the currently fenced leachfield. This assumption does not apply for the older, abandoned potential leachfield where primarily unsaturated conditions are assumed limiting lateral migration to within $5 \mathrm{ft}$ of the distal ends of lines based on previous investigations. Process knowledge of previous leachfield investigations indicate that vertical migration is not expected to infiltrate past $10 \mathrm{ft}$ below the native 
soil interface (DOE/NV, 1999a, 1999b, 2000a). This assumption applies to both the fenced leachfield and the older, potential leachfield.

\subsection{Closure Standards}

The proposed closure standards for CAU 356 characterization and verification samples are the action levels established in the DQO process (Appendix A) and restated in this section. Laboratory analytical results will be compared to these action levels to guide remediation and closure efforts. The extent of contamination will be bounded when one soil sample is below the closure standards. Clean closure will be complete when verification samples of remaining soils show levels below the closure standards.

Per the NAC 445A.2272 (NAC, 2000d), the action level for TPH is 100 milligrams per kilogram $(\mathrm{mg} / \mathrm{kg})$. If this action level for TPH is exceeded at a site, the site conditions will be evaluated in accordance with the NAC 459.9973 (1) (a-k) factors to determine if any corrective action will be required (NAC, 2000e). Remaining chemical constituents will be compared to the U.S. Environmental Protection Agency (EPA) Region 9 risk-based Preliminary Remediation Goals (PRGs) for industrial soils (EPA, 2000). If constituents are encountered that have no established PRG, a similar protocol as EPA Region 9 (risk-based calculation) may be used in establishing an action level.

Background concentrations for RCRA metals will be evaluated when natural background exceeds the PAL (i.e., arsenic). A sediment sampling effort performed by the Nevada Bureau of Mines and Geology (NBMG, 1998) provides relevant analytical data for numerous metals, including the eight RCRA metals. Statistical analysis of this data indicate background concentrations (mean plus two standard deviations) applicable to soil samples collected from the NTS for investigation of CASs (Moore, 1999).

The PALs for radionuclides are isotope-specific and defined as the maximum concentration for that isotope found in environmental samples taken from an undisturbed background location in the vicinity of the NTS, as presented in McArthur and Miller (1989), Atlan-Tech (1992), and Black and Townsend (1996). 


\subsection{Field Activities and Closure Objectives}

This section of the SAFER Plan provides a description of the field activities and closure objectives for CAU 356. The rationale for the field activities is to determine the nature and extent of any contamination present so that corrective action alternatives may be selected and implemented. All sampling activities will be conducted in compliance with the Industrial Sites Quality Assurance Project Plan (QAPP) (DOE/NV, 1996b) and other applicable, approved procedures and instructions.

Field activities will be performed in accordance with the current version of the IT Corporation, Las Vegas Office (ITLV), Health and Safety Plan (HASP) (IT, 2000) and an approved SSHASP prepared prior to the field effort. As required by the U.S. Department of Energy (DOE) Integrated Safety Management System (ISMS) (DOE, 1996), these documents outline the requirements for protecting the health and safety of the workers and the public, and the procedures for protecting the environment. The ISMS program requires that site personnel will take every reasonable step to reduce or eliminate the possibility of injury, illness, or accidents, and to protect the environment during all project activities. The following safety issues will be taken into consideration when evaluating the hazards and associated control procedures for field activities discussed in the SSHASP:

- Potential hazards to site personnel and the public include, but are not limited to: radionuclides, chemicals (e.g., heavy metals, VOCs, SVOCs, and TPHs), adverse and rapidly changing weather, remote location, and motor vehicle and heavy equipment operations.

- Proper training of all site personnel to recognize and mitigate the anticipated hazards.

- Work controls to reduce or eliminate the hazards including engineering controls, substitution of less hazardous materials, and personal protective equipment (PPE).

- Occupational exposure monitoring to prevent overexposures to hazards such as radionuclides, chemicals, and physical agents (e.g., heat, cold, and high wind).

- Radiological surveying for alpha/beta and gamma emitters to minimize and/or control personnel exposures. Use of the "as-low-as-reasonably-achievable" principle when dealing with radiological hazards. 
- Emergency and contingency planning and communications to include medical care and evacuation, decontamination, and spill control measures, and appropriate notification of project management.

\subsection{Contaminants of Potential Concern}

All soil and liquid samples collected in Phase I for any CAS will be analyzed in the laboratory for a full suite of analytes to include VOCs, SVOCs, RCRA metals, polychlorinated biphenyls (PCBs), TPH full range, and gamma spectrometry. If sludge is recoverable in the septic tank, it may also be analyzed for Toxicity Characteristic Leaching Procedure (TCLP) VOCs, TCLP SVOCs, and TCLP RCRA metals and gamma spectrometry. The analytical requirements and methods for these COPCs are listed in Table 6-2. If a CAS advances to the second phase, the list of COCs will be revised based on Phase I results, and DOE and Nevada Division of Environmental Protection (NDEP) will be notified.

\subsection{Remediation}

The DQOs developed for CAU 356 identified data gaps that require additional data collection prior to implementing the preferred closure alternative for each CAS. A phased approach has been chosen to address the data collection activities. Biased sampling will be conducted at CAU 356 during Phase I and Phase II. Process knowledge indicates that contamination, if any, is confined to the spatial boundaries of the sites as defined in the DQO process and conceptual model. If COCs are located within a CAS based on Phase I results, that CAS will be further assessed in a Phase II investigation before implementing a corrective action alternative. The COPCs determined not to be present in Phase I will be eliminated for further consideration during a Phase II characterization effort. It is important to note that the target population(s) to be investigated in Phase I may be different than those in Phase II; therefore, the target populations for each phase are documented in the relevant sections.

\subsubsection{Phase I Activities}

The objective of the Phase I investigation strategy is to determine whether COCs are present. Laboratory analytical results from this phase will be used to confirm the presence or absence of COPCs, and if the concentrations exceed PALs.

The Phase I sampling strategy targets locations and media most likely to be contaminated. Biasing factors to be considered when choosing the sample locations for this investigation are discussed in 
Section A.2.3 and Table A.2-1 of Appendix A. Biased sample locations will be determined by the Site Supervisor based on the culmination of all the biasing data generated throughout the investigation (e.g., configuration of mud pits, field observations, field-screening results). Additional samples may be collected for waste management characterization and disposal purposes.

Field screening may be instituted in the field to assist in providing additional semiquantitative screening measurements. These field-screening results (FSRs), along with other biasing factors, may help guide the selection of the most appropriate sampling location for collection of laboratory samples. Potential field-screening methods, with the respective field-screening level (FSLs), are presented below:

- VOC headspace screening levels are established at 20 parts per million (ppm) or 2.5 times background, whichever is greater, using a photoionization detector.

- The radiation (alpha/beta) screening level is defined as the mean surficial-background activity level plus two times the standard deviation of that mean.

- TPH screening levels are established at 100 ppm, using Hanby or other appropriate field test kit. Soil will be field screened for TPH only at the mud pit/mud landfill sites.

Site preparation activities for each CAS are documented below in the relevant sections.

\subsubsection{CAS 03-04-01, Area 3 Change House Septic System}

The sampling strategy for the Area 3 Change House Septic System will be similar to activities outlined in the Work Plan for Leachfield Corrective Action Units (DOE/NV, 1998). Phase I activities at this CAS will consist of confirming the configuration of system components and sample collection of the following target populations: the COC concentrations of liquid and sludge phases of the septic tank; sludge/sediment within the distribution box/manhole; surface soil above the leachrock and soil below and adjacent to the leachrock/native soil interface within the leachfield; and soil adjacent to/beneath the septic tank and distribution box (e.g., outlet pipe, tank bottom).

Site preparation activities will consist of removing tumbleweeds from the leachfield area, inspecting the surface features of the fenced leachfield, conducting a radiological survey, and locating and verifying the configuration of the septic system components through intrusive investigation. If additional distribution structures and/or leachfields are identified, they will be inspected for 
configuration and sampled in a similar manner as outlined below. Visual inspection, video surveys, and/or geophysical surveys may also be conducted to investigate the distribution lines associated with this CAS. Excavation using a backhoe will be the primary intrusive investigation technique to expose all subsurface structures during Phase I activities.

Samples of both the liquid and sludge phases from both chambers within the septic tank will be collected and analyzed, if recoverable. A sediment/soil sample will be collected within the manhole in an appropriate area as determined by field observations. Additional biased locations to be sampled include the underlying soil at both the inlet and outlet ends of the septic tank, and the identified outlet end(s) of the manhole/distribution box. To facilitate the closure of the septic tank under NAC requirements, integrity samples will be collected during Phase I in soils adjacent and/or beneath the septic tank and manhole/distribution box to confirm releases have not occurred from these structures. The tank dimensions, construction, and volume of septage will be documented for closure purposes.

A minimum of three biased locations within each identified leachfield will be sampled. These biased locations will target areas most likely to have been contaminated by effluent disposal and provide a "worst-case" scenario. These sample results will aid in confirming whether or not the leachfield component of the septic system requires a Phase II investigation. The exact locations within each leachfield will be selected by the Site Supervisor based upon site characteristics determined through field observations. For the currently fenced leachfield, samples may potentially consist of soil collected within the top 12 inches (in.) of leachfield cover to capture COPCs that may have migrated to the surface due to saturated conditions. A second sample interval will be collected in the first 12 in. of soil immediately beneath the leachrock base. If the configuration of the leachfield indicates a lagoon-type configuration without distribution lines and/or leachrock, only surface samples (0 to 12 in.) will be collected.

If the presence of the second, abandoned leachfield is confirmed, only one discrete sample per location will be collected and analyzed. The sample will be collected from the first $12 \mathrm{in}$. of soil beneath the leachrock base in accordance with assumptions of contaminant distribution described in the conceptual site model. Additional samples will be collected if the configuration and/or field observations indicate the need for supplemental sample locations and/or intervals. Figure A.2-1 in 
Appendix A shows the potential sample locations based on the current conceptual model and assumptions about the configuration of the leachfield(s).

The collection lines upstream from the septic tank will be investigated using visual inspection, video surveys, and/or geophysical surveys. The investigation will focus on collection line junctions in the upper sections of the piping system originating from buildings identified for industrial uses (e.g., Machine Shop). These buildings are assumed to be primary contributors of potentially hazardous constituents (as opposed to sanitary waste). If visual inspection or the video survey locate sufficient quantities of sediment at the junctions, samples will be collected. If the results are inconclusive, the pipe will be breached at a nominal midpoint, and an attempt will be made to collect a sediment sample at that location. Soil samples beneath the piping will also be collected at these sampled locations to confirm the integrity of the piping system. Any samples collected will be analyzed for the chemical and radiological parameters provided in Section 3.1. The septic system piping will be sealed (i.e., grouted) at each input building location to isolate the piping system from future use.

All necessary closure activities associated with the septic tank will be considered Phase I activities and are discussed in Section 3.3 and Section 3.5.

\subsubsection{CASs 03-09-01, 03-09-03, 03-09-04, 03-09-05, Mud Pits}

Phase I activities at these CASs will consist of determining the configuration of each mud pit and sample collection for laboratory analysis of the following target population: the COC concentrations within mud/soil cuttings from the surface to the textural discontinuity. The sampling strategy consists of biased sampling.

Several site preparation activities and preliminary investigation techniques must be completed prior to sampling activities for the Area 3 mud pit CASs. These activities include the following:

- Removing tumbleweeds from within each pit

- Inspecting the surface features of each pit for staining, debris, etc.

- Constructing access ramps into pits, where required, for backhoe and personnel entrance

- Conducting radiological surveys within each pit

- Conducting geophysical surveys within each pit 
Geophysical surveys will be performed within the spatial boundaries of each mud pit to facilitate the selection of biased sample locations, determine the configuration of each pit (e.g., construction of base), and identify the presence of debris within the pits. The surveys may be extended several feet past the boundaries to gather data on contrasting soil characteristics. The geophysical surveys will consist of imaging methods to identify the transition between the mud and the sands/gravels of native soil.

Although radionuclides are not expected COCs, a radiological survey will be performed over the entire surface of each mud pit, if feasible, to identify any potential areas of elevated radiological readings. If other biasing factors are inconclusive in selecting the sample location (see Table A.2-1 in Appendix A), field screening for TPH may be conducted to further enhance the selection of sample areas most likely to be contaminated. A sample target area (selected based on geophysics, field observations, and discretion of the Site Supervisor) 40-ft by 40-ft will be divided into 10 -ft grids where surface samples will be collected from the center of each grid for a total of 16 TPH-screening samples. The grid locations with the highest TPH FSRs will then be considered, along with other biasing data collected, in selecting the sample point for surface and subsurface sample collection and laboratory analysis.

Each mud pit will be sampled at a minimum of two biased locations within the defined spatial boundaries. Each sample location will consist of two discrete samples unless the configuration and depth of mud at a given location precludes two separate depths (i.e., less than 12 in.), in which case only one sample will be collected at that particular location. One sample will be collected at the surface (0 to 6 in.) within the mud/soil cuttings matrix while the second sample will consist of an approximate 6-in. interval comprised of mud and native soil at the textural discontinuity. Collecting both mud and native soil at this discontinuity ensures that contamination, if present, will be captured whether it is bound in the mud matrix or leached into the native soil. Additional material adjacent to the initial sample location may be collected to ensure sufficient volume is submitted to satisfy analytical requirements. Figure A.2-2 in Appendix A shows both a planar view and cross-sectional view of potential sample locations, based on the conceptual model for the mud pits. Exact sample locations will be determined in the field by the Site Supervisor. Locations will be selected in areas most likely to be contaminated based on the conceptual model and other biasing factors outlined in Step 3 (e.g., field-screening, geophysics). 
The mud spill of CAS 03-09-01 will not be sampled during the Phase I activities. The mud characteristics at this location can be considered consistent with the results of the return mud pit and suction mud pit associated with this CAS. Therefore, the analytical results from these two muds pits will be utilized to determine if any further characterization strategies are necessary at this location during the Phase II efforts.

Only one housekeeping activity has been identified for the mud pits in Area 3 and involves the gravel/asphalt debris pile located within the spatial boundaries of the mud pit at CAS 03-09-05. The remaining debris pile will be removed through housekeeping operations. Any additional housekeeping activities identified during the course of the investigation will be documented in the Closure Report.

\subsubsection{CAS 20-16-01, Landfill and CAS 20-22-21, Drum(s)}

Phase I activities at this CAS will consist of housekeeping activities to remove drums associated with CAS 20-22-21; determining the configuration of the mud pit at the base of the crater; and sample collection of the following target population: the COC concentrations within mud/soil cuttings from the surface to the textural discontinuity. The sampling strategy for CAS 20-16-01 consists of biased locations within (1) the mud pit located at the base of the crater, (2) the shallow mud area located at the top of the crater near the access/discharge area, and (3) the original mud pit system for the U20b emplacement hole located on the northern edge of the crater.

Site preparation activities are minimal at this CAS and should consist primarily of health and safety precautions for accessing the crater. Access into the crater is restricted for heavy machinery due to steep slopes and rocky surfaces. Therefore, all sampling will be conducted by manual means. Personnel can access the base of the crater by foot.

Several areas within and around the crater require housekeeping removal activities. Miscellaneous debris including concrete slabs, a small wooden building, wood pieces, metal objects, and cables will be removed as housekeeping items. The CAS 20-22-21, containing two drums of unknown content, has been approved for transfer into CAU 356 from CAU 352 in order to expedite remediation (Liebendorfer, 2001). Closure activities for CAS 20-22-21 will consist of housekeeping actions to remove the two drums for disposal. These activities will be documented in the Closure Report. Soil sample collection associated with housekeeping activities may be conducted in areas of debris 
removal at the discretion of the Site Supervisor based on field observations (e.g., soil staining). Contents of drums, if present and unknown, may be sampled for waste determination purposes.

The mud disposal landfill at the base of the crater will be sampled at a minimum of two locations, to be determined by the Site Supervisor based upon geophysical results and field observations. Each sample location will consist of two discrete samples unless the configuration and depth of mud at a given location precludes two separate depths, in which case only one sample will be collected at that particular location. One sample will be collected at the surface (0 to 6 in.) within the mud matrix, while the second sample will consist of an approximate 6-in. interval comprised of both mud and native soil at the textural discontinuity. Collecting both mud and native soil at this discontinuity ensures that contamination, if present, will be captured whether it is bound in the mud matrix or leached into the native soil. Additional material adjacent to the initial sample location may be collected to ensure sufficient volume is submitted to satisfy analytical requirements.

The shallow mud area near the top of the crater will be sampled at one location, to be determined by the Site Supervisor based upon site characteristics. The sample location will consist of one sample collected at the surface ( 0 to 6 in.) within the mud matrix. Additional material adjacent to the initial sample location may be collected to ensure sufficient volume is submitted to satisfy analytical requirements.

The mud pit system assumed to have been used during the drilling of the U20b emplacement hole will be sampled at a minimum of two biased locations to verify that COCs are not present that could potentially migrate into the landfill mud at the base of the crater.

\subsubsection{Phase II Activities}

Phase II efforts will consist of further characterizing sites where COCs were confirmed to be present during the Phase I activities. Laboratory analytical results from this phase will be used to determine the extent of contamination at concentrations exceeding PALs. The data collected from this phase will be used to determine if the preferred corrective action is closure-in-place or clean closure.

Environmental soil samples may be field screened to guide sample collection activities, to assist in waste management decisions, and to provide health and safety information provided that the COCs 
identified in Phase I have an appropriate screening method. Field-screening methods and FSLs will be documented prior to the start of sampling activities.

\subsubsection{CAS 03-04-01, Area 3 Change House Septic System}

Phase II activities for the septic system may include conducting additional characterization of one or both leachfields. Sample collection will target the following populations: the COC concentrations of surface soil above the leachrock and soil below and adjacent to the leachrock/native soil interface within the leachfield.

To investigate the vertical and lateral extent of contamination, subsurface samples will be collected. Each sample collected will be submitted to the laboratory for analysis for the COCs identified in Phase I. Due to the potential for overflow conditions, surface samples will also be collected at the fenced leachfield only to bound lateral surface contamination. Initial sample locations are tentatively planned for all corners of the leachfield(s) within the physical boundaries with step-out locations to be determined by site conditions. Figure A.3-1 in Appendix A shows the tentative locations for Phase II sampling. If a breach of any kind is identified within the fenced leachfield boundary, a step-out will be positioned at that location to capture the greatest potential for overflow contamination. Vertical samples will also be collected at the Phase I sample location with the highest concentrations of COCs.

Extent of contamination is the area of contiguous contamination with COC concentrations. Lateral and vertical extent of contamination will be bounded by analytical results that show concentrations of COCs below PALs. If any of the step-out analytical results indicate COCs are still present, additional step-out locations will be sampled until it can be demonstrated that COC concentrations below PALs have been achieved. If results indicate the extent of contamination extends beyond $50 \mathrm{ft}$ of the spatial boundaries and/or an increasing trend in contaminant concentrations, the conceptual model has failed and the investigation may need to be rescoped.

\subsubsection{CASs 03-09-01, 03-09-03, 03-09-04, and 03-09-05, Mud Pits and Mud Pit Spill Over}

Subsurface soil sampling will be conducted to determine the extent of COC contamination. Hand auguring, backhoe excavation, or direct-push will be the primary investigation techniques for these 
CASs. If the vertical extent of contamination is deeper than the limits of these techniques, an appropriate drilling technique will be used.

To investigate the vertical and lateral extent of contamination, subsurface samples will be collected. Each sample will be submitted to the laboratory for analysis for the COCs identified in Phase I. Initial sample locations are tentatively planned for all corners of the mud pits within the physical boundaries, with step-out locations to be determined by site conditions. Figure A.3-1 in Appendix A shows the tentative locations for the first two sets of sample locations. Vertical samples may also be collected at the Phase I sample location with the highest concentrations of COCs.

Extent of contamination is the area of contiguous contamination with COC concentrations above PALs. Lateral and vertical extent of contamination will be bounded by analytical results that show concentrations of COCs below PALs. If any of the step-out analytical results indicate COCs are still present, additional step-out locations will be sampled until it can be demonstrated that COC concentrations below PALs have been achieved. If results indicate the extent of contamination extends beyond $50 \mathrm{ft}$ of the spatial boundaries and/or an increasing trend in contaminant concentrations, the conceptual model has failed and the investigation may need to be rescoped.

\subsubsection{CAS 20-16-01, Landfill}

Subsurface soil sampling will be conducted to determine the extent of COC contamination. Hand auguring or other manual means will be the primary investigation technique for this CAS. Due to the geographic access limitations of this site, excavation or direct-push techniques are not feasible.

To investigate the vertical and lateral extent of contamination, an attempt will be made to collect samples from below the textural discontinuity. Each sample will be submitted to the laboratory for analysis for the COCs identified in Phase I. Lateral and vertical extent of contamination will be bounded by analytical results that show concentrations of COCs below PALs. If any of the step-out analytical results indicate COCs, additional step-out locations will be sampled until it can be demonstrated that COC concentrations below PALs have been achieved. If bedrock refusal is encountered before the extent has been determined, investigation techniques will be reevaluated. 


\subsection{Verification}

Verification sampling of subsurface soil will be required at CASs where soil excavation and removal are required as part of the closure activities (e.g., stained soil beneath housekeeping waste or clean closure alternative). The verification sampling must be of sufficient quality and quantity to show that any remaining COCs are less than closure standards (i.e., PALs). Typically, verification soil samples are collected from the sidewalls and bottom of an excavation. Sidewall samples are collected from the zone of impacted soil. If analytical results are above closure standards, additional soil excavation and verification sampling will be conducted until the closure criteria are met.

Soil verification samples must be collected at the septic tank to show either: (1) that leakage has not occurred from the tank, or (2) if leakage has occurred, that soil remaining after excavation in impacted areas is below closure standards. At a minimum, one soil verification sample will be collected from the base horizon at each end of the tank. If tank contents are determined to be hazardous, verification samples of the final rinsate will be collected and analyzed for the appropriate COCs.

\subsection{Data Quality Objectives}

The DQOs are qualitative and quantitative statements that specify the quality of the data required to support potential closure alternatives for CAU 356. The DQOs were developed to clearly define the purposes for which environmental data will be used and to design a data collection program that will satisfy these purposes. The formulation of a CSM is an aid to the development of DQOs for the site.

Details of the DQO process are presented in Appendix A. During the DQO discussions for this CAU, the informational inputs or data needs to resolve problem statements and decision statements were documented. Criteria for data collection and analysis were defined and agreed upon, and the appropriate QA/QC required for particular data collection activities were assigned. The analytical methods and reporting limits prescribed through the DQO process, as well as the data quality indicators (DQI) for laboratory analysis such as precision and accuracy requirements, are provided in more detail in Section 6.0 of this SAFER Plan. At the end of the investigation, resulting laboratory data will be evaluated to confirm or revise the conceptual model and determine if the DQOs were met by using the DQIs of precision, accuracy, representativeness, completeness, and comparability.

Other DQIs may be used, such as sensitivity. 


\subsection{Closure}

The following activities, at a minimum, have been identified for closure of the site. The decision logic behind the activities is provided in Figure 1-2:

- Sufficient data will be collected and analyzed to determine the nature and extent of contamination so that the appropriate corrective action alternative may be selected and implemented.

- If closure-in-place is the preferred corrective action alternative, the appropriate use restrictions will be implemented and documented in the Closure Report (CR).

- If clean closure is the preferred corrective action alternative, the material to be remediated will be removed and disposed as waste, and verification samples will be collected in remaining soil. Verification analytical results will be documented in the CR.

- Closure activities for the septic tank will include pumping out the tank contents for disposal, and either removing the tank structure or leaving in place and backfilling according to NAC regulations (i.e., backfilling with inert material, such as sand or cement); grouting of any open access points along collection lines; and sampling tank contents for characterization and waste determination.

- Housekeeping waste will be removed and photodocumented and, if required, soil verification sampling will be conducted for appropriate COCs.

- All completed activities in support of the closure of CAU 356 will be documented in a CR.

\subsection{Duration}

After submittal of the Final SAFER Plan for CAU 356 to NDEP (FFACO milestone deadline of August 28, 2001), the following is a tentative schedule of activities (in calendar days):

- Day 0: Preparation for field investigation will begin.

- Day 60: The field investigation, including sampling, will commence. Samples will be shipped to meet applicable holding times.

- Day 150: The field investigation will be completed. Laboratory analytical data will be submitted.

- Day 215: The quality-assured, analytical data will be available for NDEP review. 


\subsection{Reports and Records Availability}

A daily report will be prepared summarizing all field activities conducted that day. The report will include the project accomplishments, problems encountered, and personnel and equipment utilized. The report will be submitted to the U.S. Department of Energy, National Nuclear Security Administration Nevada Operations Office's Environmental Restoration Division (ERD) Task Manager for submittal to NDEP.

Upon completion of the field activities, a closure report will be prepared to include the following:

- Introduction (Purpose and Scope)

- Closure Activities (Description of Field Activities)

- Waste Disposition

- Conclusions (Data Quality Assessment)

This document is available in the DOE public reading rooms located in Las Vegas and Carson City, Nevada, or by contacting the ERD Project Manager. The NDEP maintains the official Administrative Record for all activities conducted under the auspices of the FFACO. 


\subsection{Waste Management}

Management of investigation-derived waste (IDW) and remediation waste will be based on regulatory requirements, field observations, process knowledge, and the analytical results of the CAU 356 investigation samples. Decontamination activities will be performed according to approved procedures specified in the contractor field sampling instructions and, as appropriate, for the COPCs identified for this CAU.

Waste other than soil (such as nonreusable sampling equipment, PPE, and rinsate) is considered potentially contaminated waste only by virtue of contact with potentially contaminated media. Therefore, sampling and analysis of the IDW, separate from analyses of site investigation samples, may not be necessary. However, if associated investigation samples are found to contain COCs above regulatory levels, rinsate samples will be taken to support waste management activities. The data generated as a result of the site investigation, along with process knowledge, will be used whenever possible to assign the appropriate waste type (i.e., nonhazardous, hazardous, low-level radioactive waste [LLW], or mixed) to the IDW. If generated, IDW will be managed and disposed of in accordance with DOE Orders, U.S. Department of Transportation (DOT) regulations, RCRA regulations, State of Nevada requirements, and agreements and permits between DOE and NDEP.

No process knowledge has been identified to indicate the release or disposal of any listed hazardous waste. Therefore, if contaminants are identified, they will be considered characteristic rather than listed wastes.

\subsection{Waste Minimization}

Corrective action investigation activities have been planned to minimize IDW generation. To minimize the amount of rinsate generated, decontamination activities will only use the volume of water necessary to decontaminate equipment and personnel. Reusable equipment (such as booties, high-density polyethylene (HDPE) sheeting, and metal spoons) will be utilized and decontaminated for future use, whenever possible. The use of disposable equipment will be eliminated, where feasible. Any IDW generated, such as disposable sampling equipment, decontamination rinsate, and PPE will be segregated to the greatest extent possible to minimize the generation of hazardous, 
radioactive, and/or mixed waste. IDW may also be decontaminated to facilitate sanitary disposal, if possible.

\subsection{Potential Waste Streams}

Potentially contaminated waste generated during the investigation activities will be managed in separate waste streams which include:

- Debris and associated trace amounts of soil

- $\quad$ PPE; nonreusable sampling equipment (e.g., plastic, aluminum foil); and plastic or HDPE sheeting (i.e., from equipment linings, decontamination areas, hazardous waste accumulation areas [HWAAs], soil staging areas, sample preparation areas, and beneath sampling equipment)

- Decontamination rinsate

- Septic tank residues

- TPH field-screening residues

- Soil and/or debris associated with closure activities

Waste will be traceable to its source and individual samples; this information will be recorded in the waste management logbook.

\subsection{Management of Remediation and Investigation-Derived Waste}

Management requirements for nonhazardous (i.e., solid/sanitary), hydrocarbon, hazardous, LLW, and mixed waste are discussed in the following sections. The IDW generated will be managed as potentially hazardous waste and potentially radioactive waste until laboratory results indicate either the presence or absence of RCRA-regulated constituents and/or radioactive constituents, respectively. Applicable waste management regulations and requirements are listed in Table 5-1.

Generally, remediation waste will be characterized prior to generation. Once a waste stream is characterized, a disposal location will be selected. The waste will be packaged based on the waste acceptance criteria specified by the disposal location, transportation requirements, and logistics. 
Table 5-1

Waste Management Regulations and Requirements

\begin{tabular}{|c|c|c|}
\hline Waste Type & $\begin{array}{c}\text { Federal } \\
\text { Regulation }\end{array}$ & Additional Requirements \\
\hline Nonhazardous (solid/sanitary) & NA & $\begin{array}{l}\text { NRS } 444.440-444.620^{\mathrm{a}} \\
\text { NAC } 444.570-444.7499^{\mathrm{b}} \\
\text { Landfill Permit }^{\star}\end{array}$ \\
\hline Hydrocarbon & NA & $\begin{array}{l}\text { NAC 445A.2272 } \\
\text { Landfill Permit }^{\star *}\end{array}$ \\
\hline Hazardous & RCRA & $\begin{array}{l}\text { NRS } 459.400-459.600^{d} \\
\text { NAC } 444.850-444.8746^{e} \\
\text { POC }^{f}\end{array}$ \\
\hline Low-Level Radioactive & NA & DOE Orders and NTSWAC ${ }^{g}$ \\
\hline Mixed & RCRA & $\begin{array}{l}\text { NTSWAC } \\
\text { POC }^{f}\end{array}$ \\
\hline
\end{tabular}

${ }^{a}$ Nevada Revised Statutes (NRS, 1999a)

${ }^{\mathrm{b}}$ Nevada Administrative Code (NAC, 2000b)

${ }^{\mathrm{c}}$ Nevada Administrative Code (NAC, 2000d)

${ }^{\mathrm{d} N e v a d a}$ Revised Statutes (NRS, 1999b)

${ }^{\mathrm{e}}$ Nevada Administrative Code (NAC, 2000c)

${ }^{\dagger}$ Performance Objective for the Certification of Nonradioactive Hazardous Waste (BN, 1995)

${ }^{9}$ Nevada Test Site Waste Acceptance Criteria, Rev. 3 (DOE/NV, 2000b)

${ }^{*}$ Area 9, U10c Crater

${ }^{* *}$ Area 6 , Hydrocarbon Landfill

NA $=$ Not Applicable

\subsubsection{Nonhazardous Waste (Solid/Sanitary)}

Sanitary waste not directly associated with sampling activities typically consists of plastic, food, and paper products. This waste will be contained in plastic bags and transported to an approved solid waste management unit.

\subsubsection{Hydrocarbon Waste}

The action level for soil contaminated with hydrocarbons is $100 \mathrm{mg} / \mathrm{kg}$ in the State of Nevada (NAC, 2000d). Soils and associated IDW with TPH levels above $100 \mathrm{mg} / \mathrm{kg}$ and containing RCRA-regulated constituents below regulatory limits shall be managed as hydrocarbon waste and disposed of in accordance with all applicable regulations. 


\subsubsection{Hazardous Waste}

Suspected hazardous waste will be managed in accordance with RCRA and State of Nevada hazardous waste management regulations and interpreted as follows. Suspected hazardous waste will be placed in containers that meet DOT specifications in accordance with 49 Code of Federal Regulations (CFR), Part 178 (CFR, 1999c). Container markings and field records will allow wastes to be traceable back to the source. Additionally, waste may be directly sampled for characterization purposes. The type of container used will be appropriate for the particular waste in storage, as specified in 40 CFR 265.172 (CFR 1999a). No incompatible waste is expected to be generated; however, if incompatible waste is encountered in the field, it will be managed in accordance with 40 CFR 265.177 (CFR, 1999b).

Hazardous waste will be characterized in accordance with the requirements of 40 CFR 261 (CFR, 2000). Characterization will be based on analytical data, FSRs, process knowledge, or a combination thereof. Containerized wastes pending characterization will be identified with "Pending Analysis" markings until their regulatory status can be determined. Depending on the nature and amount of waste generated, waste management control areas may be established, such as a Satellite Accumulation Area (SAA) or HWAA.

Waste that is determined to be hazardous will be transported to the Area 5 Hazardous Waste Storage Unit or shipped directly to a licensed treatment storage and disposal facility within fifteen days from the completion of its characterization. If transportation cannot be completed within fifteen days, a schedule indicating the shipment date will be provided to NDEP. Characterization is deemed complete once all data relating to the IDW has been validated, reviewed, and a waste characterization report finalized. When shipped off-site, hazardous waste will be transported by a licensed hazardous waste hauler and accompanied by a Uniform Hazardous Waste Manifest in accordance with DOT shipping requirements. A copy of the manifest will be provided to the NDEP in accordance with State of Nevada regulatory requirements.

At a minimum, hazardous waste (which may contain rinsate) generated during this investigation will comply with the Nevada Test Site Performance Objective for Certification of Nonradioactive Hazardous Waste (BN, 1995). 


\subsubsection{Low-Level Radioactive Waste}

Low-level radioactive wastes are not expected to be generated. However, any LLW generated will be managed and characterized in accordance with DOE Orders and the requirements of the Nevada Test Site Waste Acceptance Criteria (NTSWAC) (DOE/NV, 2000b) and the ITLV Waste Certification Program Plan. Characterization will be based on analytical data, FSRs, process knowledge, or a combination thereof. Potentially contaminated IDW, such as PPE, will be placed in clear plastic bags marked with the date and the associated sample locations and/or sample numbers. The plastic bags and any other LLW, such as containerized soil, will be placed in marked packages meeting DOT specifications and locked or fitted with tamper-indicating devices. The waste will be staged at a designated HWAA/Radioactive Controlled Area or a HWAA/Radioactive Materials Area pending disposal in accordance with NTSWAC requirements (DOE/NV, 2000b). Drums will be marked "Radioactive Material Pending Analysis" until a final waste determination can be made.

Rinsate from decontamination activities may be analyzed to determine final disposition. Gross alpha and gross beta analysis may be performed on rinsate samples and the results will be used to determine final disposition. Additionally, the soil characterization results may be applied to the rinsate as part of the determination of final disposition. If rinsate is categorized as LLW, it will be solidified prior to NTSWAC certification activities and disposed of at a NTS Radioactive Waste Management Site (RWMS). Other disposal alternatives not requiring solidification may be available after the waste is generated and specific characteristics of the waste are known.

Any waste to be disposed of in LLW landfills at the NTS will be characterized in accordance with the requirements of the NTSWAC and the contractor-specific waste certification program plan and implementing procedures.

\subsubsection{Mixed Waste}

Mixed waste is a combination of hazardous and radioactive waste. If generated, this waste will be managed in accordance with RCRA (CFR, 2000) and NAC regulations (NAC, 2000a), as well as DOE requirements for radioactive waste. Where there is a conflict in regulations or requirements, the most stringent shall apply. For example, the accumulation time limit and weekly inspections per RCRA regulations will be applied to mixed waste even though it is not required for radioactive waste. 
Conversely, while RCRA does not require documented traceability, the NTSWAC for LLW does; therefore, traceability shall be documented.

In general, mixed waste will be managed in the same manner as hazardous waste with added mandatory radioactive waste management program requirements. Suspected mixed waste will be managed in accordance with applicable regulations, requirements, and ITLV standard practices. Containers will be marked with the words "Waste Pending Analysis," pending characterization. However, once the waste determination is made, mixed waste shall be transported via an approved hazardous waste hauler to the NTS transuranic waste storage pad for storage pending treatment or disposal. Mixed waste with hazardous waste constituents meeting land disposal restrictions may be disposed of at the Area 5 RWMS. Mixed waste not meeting land disposal restrictions will require development of a treatment plan under the requirements of the Mutual Consent Order between DOE and the State of Nevada (NRS, 1999b).

\subsection{Analysis Required for the Disposal of IDW}

Additional analytical data may be required to characterize the IDW (e.g., TCLP analysis on septic tank residues). These analyses will support waste classification to meet the waste acceptance criteria prior to the disposal at on-site NTS and off-site locations. Each of the CASs has been reviewed to ensure that sufficient analyses to support IDW disposal have been planned. The analyses required for IDW are summarized in Table 5-2. Samples submitted for laboratory analysis will be analyzed according to Table 6-2. Rinsate generated during the investigation may be analyzed for any or all COPCs, based on site characterization analytical data. 
Table 5-2

Analysis Required for the Disposal of IDW

\begin{tabular}{|l|c|c|c||}
\hline \multicolumn{1}{|c|}{ Corrective Action Site } & $\begin{array}{c}\text { Isotopic } \\
\text { Uranium }\end{array}$ & $\begin{array}{c}\text { Isotopic } \\
\text { Plutonium }\end{array}$ & $\begin{array}{c}\text { Percent of } \\
\text { Samples }\end{array}$ \\
\hline \hline $\begin{array}{l}\text { CAS 03-04-01 } \\
\text { Area 3 Change House Septic System }\end{array}$ & required & required & $10 \%$ \\
\hline $\begin{array}{l}\text { CAS 03-09-01 } \\
\text { Mud Pit Spill Over }\end{array}$ & required & required & $10 \%$ \\
\hline $\begin{array}{l}\text { CAS 03-09-03 } \\
\text { Mud Pit }\end{array}$ & required & required & $10 \%$ \\
\hline $\begin{array}{l}\text { CAS 03-09-04 } \\
\text { Mud Pit }\end{array}$ & required & required & $10 \%$ \\
\hline $\begin{array}{l}\text { CAS 03-09-05 } \\
\text { Mud Pit }\end{array}$ & required & required & $10 \%$ \\
\hline $\begin{array}{l}\text { CAS 20-16-01 } \\
\text { Landfill }\end{array}$ & required & required & $10 \%$ \\
\hline \hline
\end{tabular}




\subsection{Quality Assurance/Quality Control}

The overall objective of the closure activities described in this SAFER Plan is to collect accurate and defensible data to support the selection and implementation of a closure alternative for each CAS in CAU 356. The following two sections discuss the collection of required QC samples in the field and QA requirements for laboratory/analytical data to achieve closure. Unless otherwise stated in this SAFER plan or required by the results of the DQO process (see Appendix A), this investigation will adhere to the Industrial Sites QAPP (DOE/NV, 1996b).

\subsection{Quality Control Field Sampling Activities}

Field QC samples will be collected in accordance with established procedures. Field QC samples are collected and analyzed to aid in determining the validity of sample results. The number of required QC samples depends on the types and number of environmental samples collected. The minimum frequency of collecting and analyzing QC samples for this investigation, as determined in the DQO process, include:

- $\quad$ Trip blanks (1 per sample cooler containing VOC environmental samples)

- Equipment blanks (1 per sampling event for each type of decontamination procedure)

- Source blanks (1 per lot of source material that contacts sampled media)

- Field duplicates ( 1 per 20 environmental samples or 1 per CAS if less than 20 collected)

- $\quad$ Field blanks (1 per 20 environmental samples)

- Matrix spike/matrix spike duplicate (MS/MSD) (1 per 20 environmental samples or 1 per CAS per matrix if less than 20 collected)

Additional QC samples may be submitted based on site conditions at the discretion of the Site Supervisor. Field quality control samples shall be analyzed using the same analytical procedures implemented for environmental samples. The results of the QC sample analyses will be included in the analytical report. Additional details regarding field QC samples are available in the Industrial Sites QAPP (DOE/NV, 1996b). 


\subsection{Laboratory/Analytical Quality Assurance}

Criteria for Phase I, Phase II, and, if necessary, clean closure (as stated in the DQOs [Appendix A]) require laboratory analysis be conducted for samples used in decision making to provide a quantitative measurement of any COCs present. Rigorous QA/QC will be implemented for all laboratory samples and includes documentation, data verification, and validation of analytical results, and meeting the requirements of data quality indicators as they relate to laboratory analysis.

Data verification and validation will be performed in accordance with the Industrial Sites QAPP (DOE/NV, 1996b) and this SAFER Plan. All laboratory data from samples collected and analyzed will be evaluated for data quality according to EPA Functional Guidelines (EPA, 1994a and 1999). The data will be reviewed to ensure that all critical samples were appropriately collected and analyzed, and the results passed data validation criteria. Validated data, whether estimated (i.e., J-qualified) or not, will be assessed to determine if they meet the DQOs of the investigation and the performance criteria for the DQIs. The results of this assessment will be documented in the closure report. If the DQOs were not met, corrective actions will be evaluated, selected, and implemented (e.g., refine conceptual site model or resample to fill data gaps).

Data quality indicators are qualitative and quantitative statements that specify the data requirements for a project and include precision, accuracy, representativeness, completeness, and comparability. In addition, sensitivity has been included as a DQI for laboratory analysis. The performance criteria for each indicator has been selected based on the intended use of the data, current field and analytical procedures, and instrumentation. Precision and accuracy goals have been standardized for both organic and inorganic analytes for analytical laboratories under the EPA Contract Laboratory Program (CLP) (EPA, 1988a, 1988b). Laboratory quality control samples used to measure precision and accuracy of analytical procedures shall be analyzed using the same analytical procedures implemented for environmental samples. Additional details regarding DQIs and laboratory QC samples are available in the Industrial Sites QAPP (DOE/NV, 1996b).

Table 6-1 provides the established performance criteria for each of the DQIs and the impacts to the decision if the criteria are not met. The Industrial Sites QAPP (DOE/NV, 1996b) documents the actions to be taken to correct conditions that adversely affect data quality both in the field and the laboratory. Any deficiencies noted during the investigation that renders the data quality unacceptable will be documented in the closure report. 
Table 6-1

Laboratory/Analytical Data Quality Indicators

\begin{tabular}{|c|c|c|}
\hline $\begin{array}{l}\text { Data Quality } \\
\text { Indicator }\end{array}$ & Performance Criteria & $\begin{array}{c}\text { Impact on Decision if Performance } \\
\text { Criteria Not Met }\end{array}$ \\
\hline Precision & $\begin{array}{l}\text { Variations between duplicates (field and lab) and } \\
\text { original sample should not exceed analytical } \\
\text { method-specific criteria listed in Table 6-2. }\end{array}$ & $\begin{array}{l}\text { Estimated data within sample delivery group (SDG) } \\
\text { will be evaluated for its usability. If data determined } \\
\text { not usable, then data will not be used in decision, } \\
\text { and completeness criteria will not be met. }\end{array}$ \\
\hline Accuracy & $\begin{array}{l}\text { Laboratory control sample results and matrix spike } \\
\text { results should be within analytical method-specific } \\
\text { criteria listed in Table 6-2. }\end{array}$ & $\begin{array}{l}\text { Estimated data within SDG will be evaluated for its } \\
\text { usability. If estimated data is biased high or } \\
\text { conservative, the data may be used in decision. If } \\
\text { estimated data is biased low and below the decision } \\
\text { threshold, the data may not be used in decision and } \\
\text { completeness criteria may not be met. }\end{array}$ \\
\hline Sensitivity & $\begin{array}{l}\text { Detection limits of laboratory instruments must be } \\
\text { less then action level for COC. }\end{array}$ & $\begin{array}{l}\text { Cannot determine if COCs are present at levels of } \\
\text { concern, thereby investigation objectives cannot be } \\
\text { met. }\end{array}$ \\
\hline $\begin{array}{l}\text { Phase I } \\
\text { Completeness }\end{array}$ & $\begin{array}{l}100 \% \text { of samples submitted to laboratory } \\
100 \% \text { of requested analyses conducted } \\
100 \% \text { of critical analytes to be valid } \\
80 \% \text { of noncritical analytes to be valid }\end{array}$ & $\begin{array}{l}\text { Cannot make decision on whether COCs are present } \\
\text { with high confidence. }\end{array}$ \\
\hline $\begin{array}{l}\text { Phase II } \\
\text { Completeness }\end{array}$ & $\begin{array}{l}100 \% \text { of samples submitted to laboratory } \\
100 \% \text { of requested analyses conducted } \\
100 \% \text { of critical analytes to be valid } \\
80 \% \text { of noncritical analytes to be valid }\end{array}$ & $\begin{array}{l}\text { Decision of whether or not extent of contamination } \\
\text { has been bounded cannot be determined. }\end{array}$ \\
\hline $\begin{array}{l}\text { Clean Closure } \\
\text { Completeness }\end{array}$ & $\begin{array}{l}100 \% \text { of samples submitted to laboratory } \\
100 \% \text { of requested analyses conducted } \\
100 \% \text { of critical analytes to be valid } \\
80 \% \text { of noncritical analytes to be valid }\end{array}$ & $\begin{array}{l}\text { Decision of whether or not COCs remain in soil } \\
\text { cannot be determined. }\end{array}$ \\
\hline Comparability & $\begin{array}{l}\text { Equivalent samples analyzed using same analytical } \\
\text { methods, the same units of measurement and } \\
\text { detection limits must be used for like analyses. }\end{array}$ & Inability to use data compiled in previous phases. \\
\hline Representativeness & $\begin{array}{l}\text { Correct analytical method performed for appropriate } \\
\text { COPC; valid data reflects appropriate target } \\
\text { population. }\end{array}$ & $\begin{array}{l}\text { Cannot identify COC or estimate concentration of } \\
\text { COC; therefore, cannot make decision(s) on target } \\
\text { population. }\end{array}$ \\
\hline
\end{tabular}

${ }^{a}$ Critical analytes are those analytes most likely present in the target population at concentrations of concern and have been identified through process knowledge of similar sites and historical documentation. Critical analytes for Phase I mud pit samples are TPH-diesel, PCBs, and chromium. Critical analytes for Phase I septic system samples are lead, PCBs, and solvents. Phase II critical samples will be determined based on Phase I analytical results. 
Table 6-2

Laboratory Chemical, Toxicity Characteristic Leaching Procedure, and Radiochemistry Analytical Requirements for Industrial Sites

(Page 1 of 4 )

\begin{tabular}{|c|c|c|c|c|c|c|}
\hline $\begin{array}{l}\text { Parameter or } \\
\text { Analyte }\end{array}$ & $\begin{array}{l}\text { Medium or } \\
\text { Matrix }\end{array}$ & $\begin{array}{l}\text { Analytical } \\
\text { Method }\end{array}$ & $\begin{array}{c}\text { Minimum Reporting } \\
\text { Limit }\end{array}$ & \begin{tabular}{|l} 
RCRA Hazardous \\
Waste \\
Regulatory Limit
\end{tabular} & $\begin{array}{l}\text { Relative Percent } \\
\text { Difference (RPD) }^{\mathrm{a}}\end{array}$ & $\begin{array}{c}\text { Percent Recovery } \\
(\% \mathbf{R})^{\mathrm{b}}\end{array}$ \\
\hline \multicolumn{7}{|c|}{ ORGANICS } \\
\hline \multirow{2}{*}{$\begin{array}{l}\text { Total Volatile Organic } \\
\text { Compounds (VOCs) }\end{array}$} & Water & \multirow{2}{*}{$8260 \mathrm{~B}^{\mathrm{c}}$} & \multirow{2}{*}{$\begin{array}{l}\text { Analyte-specific } \\
\text { estimated } \\
\text { quantitation limits } \\
\end{array}$} & \multirow{2}{*}{$\begin{array}{l}\text { Not Applicable } \\
\text { (NA) }\end{array}$} & $14^{e}$ & $61-145^{e}$ \\
\hline & Soil & & & & $24^{\mathrm{e}}$ & $59-172^{e}$ \\
\hline \multicolumn{7}{|l|}{$\begin{array}{c}\text { Toxicity Characteristic } \\
\text { Leaching Procedure (TCLP) } \\
\text { VOCs }\end{array}$} \\
\hline Benzene & \multirow{10}{*}{ Aqueous } & \multirow{10}{*}{$1311 / 8260 \mathrm{~B}^{\mathrm{c}}$} & $0.050 \mathrm{mg} / \mathrm{L}^{\mathrm{d}}$ & $0.5 \mathrm{mg} / \mathrm{L}^{\dagger}$ & \multirow{10}{*}{$14^{e}$} & \multirow{10}{*}{$61-145^{\mathrm{e}}$} \\
\hline $\begin{array}{c}\text { Carbon } \\
\text { Tetrachloride }\end{array}$ & & & $0.050 \mathrm{mg} / \mathrm{L}^{\mathrm{d}}$ & $0.5 \mathrm{mg} / \mathrm{L}^{\dagger}$ & & \\
\hline Chlorobenzene & & & $0.050 \mathrm{mg} / \mathrm{L}^{\mathrm{d}}$ & $100 \mathrm{mg} / \mathrm{L}^{\mathrm{f}}$ & & \\
\hline Chloroform & & & $0.050 \mathrm{mg} / \mathrm{L}^{\mathrm{d}}$ & $6 \mathrm{mg} / \mathrm{L}^{\mathrm{f}}$ & & \\
\hline 1,2-Dichloroethane & & & $0.050 \mathrm{mg} / \mathrm{L}^{\mathrm{d}}$ & $0.5 \mathrm{mg} / \mathrm{L}^{f}$ & & \\
\hline 1,1-Dichloroethene & & & $0.050 \mathrm{mg} / \mathrm{L}^{\mathrm{d}}$ & $0.7 \mathrm{mg} / \mathrm{L}^{\mathrm{f}}$ & & \\
\hline Methyl Ethyl Ketone & & & $0.050 \mathrm{mg} / \mathrm{L}^{\mathrm{d}}$ & $200 \mathrm{mg} / \mathrm{L}^{\mathrm{f}}$ & & \\
\hline Tetrachloroethene & & & $0.050 \mathrm{mg} / \mathrm{L}^{\mathrm{d}}$ & $0.7 \mathrm{mg} / \mathrm{L}^{\mathrm{f}}$ & & \\
\hline Trichloroethene & & & $0.050 \mathrm{mg} / \mathrm{L}^{\mathrm{d}}$ & $0.5 \mathrm{mg} / \mathrm{L}^{\mathrm{f}}$ & & \\
\hline Vinyl Chloride & & & $0.050 \mathrm{mg} / \mathrm{L}^{\mathrm{d}}$ & $0.2 \mathrm{mg} / \mathrm{L}^{f}$ & & \\
\hline \multirow{2}{*}{$\begin{array}{l}\text { Total Semivolatile Organic } \\
\text { Compounds (SVOCs) }\end{array}$} & Water & \multirow{2}{*}{$8270 C^{c}$} & \multirow{2}{*}{$\begin{array}{l}\text { Analyte-specific } \\
\text { estimated } \\
\text { quantitation limits }^{d}\end{array}$} & \multirow{2}{*}{ NA } & $50^{\circ}$ & $9-127^{e}$ \\
\hline & Soil & & & & $50^{\mathrm{e}}$ & $11-142^{\mathrm{e}}$ \\
\hline \multicolumn{7}{|l|}{ TCLP SVOCs } \\
\hline o-Cresol & \multirow{14}{*}{ Aqueous } & \multirow{14}{*}{$1311 / 8270 C^{c}$} & $0.10 \mathrm{mg} / \mathrm{L}^{\mathrm{d}}$ & $200 \mathrm{mg} / \mathrm{L}^{\dagger}$ & \multirow{14}{*}{$50^{\mathrm{e}} \quad 50^{\mathrm{e}}$} & \multirow{14}{*}{$9-127^{e}$} \\
\hline m-Cresol & & & $0.10 \mathrm{mg} / \mathrm{L}^{\mathrm{d}}$ & $200 \mathrm{mg} / \mathrm{L}^{f}$ & & \\
\hline p-Cresol & & & $0.10 \mathrm{mg} / \mathrm{L}^{\mathrm{d}}$ & $200 \mathrm{mg} / \mathrm{L}^{f}$ & & \\
\hline Cresol (total) & & & $0.30 \mathrm{mg} / \mathrm{L}^{\mathrm{d}}$ & $200 \mathrm{mg} / \mathrm{L}^{\dagger}$ & & \\
\hline $\begin{array}{l}\text { 1,4-Dichloro- } \\
\text { benzene }\end{array}$ & & & $0.10 \mathrm{mg} / \mathrm{L}^{\mathrm{d}}$ & $7.5 \mathrm{mg} / \mathrm{L}^{\mathrm{f}}$ & & \\
\hline 2,4-Dinitrotoluene & & & $0.10 \mathrm{mg} / \mathrm{L}^{\mathrm{d}}$ & $0.13 \mathrm{mg} / \mathrm{L}^{f}$ & & \\
\hline $\begin{array}{l}\text { Hexachloro- } \\
\text { benzene }\end{array}$ & & & $0.10 \mathrm{mg} / \mathrm{L}^{\mathrm{d}}$ & $0.13 \mathrm{mg} / \mathrm{L}^{f}$ & & \\
\hline $\begin{array}{l}\text { Hexachloro- } \\
\text { butadiene }\end{array}$ & & & $0.10 \mathrm{mg} / \mathrm{L}^{\mathrm{d}}$ & $0.5 \mathrm{mg} / \mathrm{L}^{\mathrm{f}}$ & & \\
\hline $\begin{array}{l}\text { Hexachloro- } \\
\text { ethane }\end{array}$ & & & $0.10 \mathrm{mg} / \mathrm{L}^{\mathrm{d}}$ & $3 \mathrm{mg} / \mathrm{L}^{\mathrm{t}}$ & & \\
\hline Nitrobenzene & & & $0.10 \mathrm{mg} / \mathrm{L}^{\mathrm{d}}$ & $2 \mathrm{mg} / \mathrm{L}^{\mathrm{f}}$ & & \\
\hline $\begin{array}{l}\text { Pentachloro- } \\
\text { phenol }\end{array}$ & & & $0.50 \mathrm{mg} / \mathrm{L}^{\mathrm{d}}$ & $100 \mathrm{mg} / \mathrm{L}^{\dagger}$ & & \\
\hline Pyridine & & & $0.10 \mathrm{mg} / \mathrm{L}^{\mathrm{d}}$ & $5 \mathrm{mg} / \mathrm{L}^{\mathrm{f}}$ & & \\
\hline $\begin{array}{l}2,4,5 \text {-Trichloro- } \\
\text { phenol }\end{array}$ & & & $0.10 \mathrm{mg} / \mathrm{L}^{\mathrm{d}}$ & $400 \mathrm{mg} / \mathrm{L}^{\dagger}$ & & \\
\hline $\begin{array}{l}\text { 2,4,6-Trichloro- } \\
\text { phenol }\end{array}$ & & & $0.10 \mathrm{mg} / \mathrm{L}^{\mathrm{d}}$ & $2 \mathrm{mg} / \mathrm{L}^{\mathrm{f}}$ & & \\
\hline
\end{tabular}


Table 6-2

Laboratory Chemical, Toxicity Characteristic Leaching Procedure, and Radiochemistry Analytical Requirements for Industrial Sites

(Page 2 of 4 )

\begin{tabular}{|c|c|c|c|c|c|c|}
\hline $\begin{array}{l}\text { Parameter or } \\
\text { Analyte }\end{array}$ & $\begin{array}{l}\text { Medium or } \\
\text { Matrix }\end{array}$ & $\begin{array}{l}\text { Analytical } \\
\text { Method }\end{array}$ & $\begin{array}{c}\text { Minimum Reporting } \\
\text { Limit }\end{array}$ & $\begin{array}{c}\text { RCRA Hazardous } \\
\text { Waste } \\
\text { Regulatory Limit }\end{array}$ & $\begin{array}{l}\text { Relative Percent } \\
\text { Different (RPD) }\end{array}$ & $\begin{array}{c}\text { Percent Recovery } \\
(\% \mathrm{R})^{\mathrm{b}}\end{array}$ \\
\hline \multicolumn{7}{|l|}{ TCLP SVOCs } \\
\hline \multirow{2}{*}{$\begin{array}{c}\text { Total } \\
\text { Pesticides }\end{array}$} & Water & \multirow[b]{2}{*}{$8081 A^{c}$} & \multirow{2}{*}{$\begin{array}{c}\text { Analyte-specific } \\
\text { Contract Required } \\
\text { Quantitation Limits } \\
(\mathrm{CRQL})^{\mathrm{e}}\end{array}$} & \multirow[b]{2}{*}{ NA } & $27^{e}$ & $38-131^{e}$ \\
\hline & Soil & & & & $50^{e}$ & $23-139^{e}$ \\
\hline \multicolumn{7}{|l|}{$\begin{array}{c}\text { TCLP } \\
\text { Pesticides }\end{array}$} \\
\hline Chlordane & \multirow{7}{*}{ Aqueous } & \multirow{7}{*}{$1311 / 8081 A^{c}$} & $0.0005 \mathrm{mg} / \mathrm{L}^{\mathrm{e}}$ & $0.03 \mathrm{mg} / \mathrm{L}^{f}$ & \multirow{7}{*}{$27^{e}$} & \multirow{7}{*}{$38-131^{e}$} \\
\hline Endrin & & & $0.001 \mathrm{mg} / \mathrm{L}^{\mathrm{e}}$ & $0.02 \mathrm{mg} / \mathrm{L}^{f}$ & & \\
\hline Heptachlor & & & $0.0005 \mathrm{mg} / \mathrm{L}^{\mathrm{e}}$ & $0.008 \mathrm{mg} / \mathrm{L}^{\mathrm{f}}$ & & \\
\hline $\begin{array}{l}\text { Heptachlor } \\
\text { Epoxide }\end{array}$ & & & $0.0005 \mathrm{mg} / \mathrm{L}^{\mathrm{e}}$ & $0.008 \mathrm{mg} / \mathrm{L}^{\mathrm{f}}$ & & \\
\hline $\begin{array}{c}\text { gamma-BHC } \\
\text { (Lindane) }\end{array}$ & & & $0.0005 \mathrm{mg} / \mathrm{L}^{\mathrm{e}}$ & $0.4 \mathrm{mg} / \mathrm{L}^{\mathrm{f}}$ & & \\
\hline Methoxychlor & & & $0.005 \mathrm{mg} / \mathrm{L}^{\mathrm{e}}$ & $10 \mathrm{mg} / \mathrm{L}^{\mathrm{f}}$ & & \\
\hline Toxaphene & & & $0.05 \mathrm{mg} / \mathrm{L}^{\mathrm{e}}$ & $0.5 \mathrm{mg} / \mathrm{L}^{f}$ & & \\
\hline \multirow{2}{*}{$\begin{array}{l}\text { Polychlorinated Biphenyls } \\
\text { (PCBs) }\end{array}$} & Water & \multirow{2}{*}{$8082^{\circ}$} & Analyte-specific & \multirow{2}{*}{ NA } & \multirow{2}{*}{ Lab-specific $^{9}$} & \multirow{2}{*}{ Lab-specific $^{9}$} \\
\hline & Soil & & $(\mathrm{CRQL})^{\mathrm{e}}$ & & & \\
\hline \multirow{2}{*}{$\begin{array}{l}\text { Total } \\
\text { Herbicides }\end{array}$} & Water & \multirow{2}{*}{$8151 A^{c}$} & $1.3 \mu \mathrm{g} / \mathrm{L}^{\mathrm{c}}$ & \multirow{2}{*}{ NA } & \multirow{2}{*}{ Lab-specific $^{9}$} & \multirow{2}{*}{ Lab-specific $^{g}$} \\
\hline & Soil & & $66 \mu \mathrm{g} / \mathrm{kg}^{\mathrm{c}}$ & & & \\
\hline \multicolumn{7}{|l|}{$\begin{array}{c}\text { TCLP } \\
\text { Herbicides }\end{array}$} \\
\hline $2,4-D$ & \multirow{2}{*}{ Aqueous } & \multirow{2}{*}{$1311 / 8151 \mathrm{~A}^{\mathrm{c}}$} & $0.002 \mathrm{mg} / \mathrm{L}^{\mathrm{d}}$ & $10 \mathrm{mg} / \mathrm{L}^{\mathrm{f}}$ & \multirow{2}{*}{ Lab-specific $^{g}$} & \multirow{2}{*}{ Lab-specific $^{9}$} \\
\hline $2,4,5-\mathrm{TP}$ & & & $0.00075 \mathrm{mg} / \mathrm{L}^{d}$ & $1 \mathrm{mg} / \mathrm{L}^{\mathrm{f}}$ & & \\
\hline \multirow{4}{*}{$\begin{array}{l}\text { Total Petroleum Hydrocarbons } \\
\text { (TPH) }\end{array}$} & $\begin{array}{c}\text { Water } \\
\text { Gasoline }\end{array}$ & \multirow{4}{*}{ 8015B modified ${ }^{\mathrm{C}}$} & $0.1 \mathrm{mg} / \mathrm{L}^{\mathrm{h}}$ & \multirow{4}{*}{ NA } & \multirow{4}{*}{ Lab-specific ${ }^{9}$} & \\
\hline & Soil Gasoline & & $0.5 \mathrm{mg} / \mathrm{kg}^{\mathrm{h}}$ & & & Lab-specific ${ }^{9}$ \\
\hline & Water Diesel & & $0.5 \mathrm{mg} / \mathrm{L}^{\mathrm{h}}$ & & & \\
\hline & Soil Diesel & & $25 \mathrm{mg} / \mathrm{kg}^{\mathrm{h}}$ & & & \\
\hline Explosives & Water & $8330^{\circ}$ & $14 \mu \mathrm{g} / \mathrm{L}^{\mathrm{c}}$ & NA & Lab-specificg & Lab-specificg \\
\hline & Soil & & $2.2 \mathrm{mg} / \mathrm{kg}^{\mathrm{c}}$ & & & \\
\hline Polychlorinated Dioxins and & Water & $8280 \wedge / 8>00^{\circ}$ & $0.05 \mu \mathrm{g} / \mathrm{L}^{\mathrm{c}}$ & $N A$ & I phanerifigg & I ebsaneifigg \\
\hline Furans & Soil & 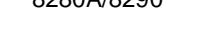 & $5 \mu \mathrm{g} / \mathrm{kg}^{\mathrm{c}}$ & 政 & Lav-specinc & Lav-spectic \\
\hline & & & INORGANICS & & & \\
\hline $\begin{array}{c}\text { Total Resource Conservation } \\
\text { and Recovery Act (RCRA) } \\
\text { Metals } \\
\end{array}$ & & & & & & \\
\hline Arcenir & Water & $6010 B^{c}$ & $10 \mu \mathrm{g} / \mathrm{L}^{\mathrm{h}, \mathrm{i}}$ & & & \\
\hline 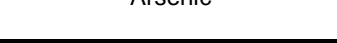 & Soil & $6010 B^{c}$ & $1 \mathrm{mg} / \mathrm{kg}^{\mathrm{h}, \mathrm{i}}$ & $\mathrm{N} / \mathrm{A}$ & $20^{i}$ & $75-125$ \\
\hline Barium & Water & $6010 B^{c}$ & $200 \mu \mathrm{g} / \mathrm{L}^{\mathrm{h}, \mathrm{i}}$ & 年 & 20 & 10 \\
\hline & Soil & $6010 \mathrm{~B}^{\mathrm{c}}$ & $20 \mathrm{mg} / \mathrm{kg}^{\mathrm{h}, \mathrm{i}}$ & & & \\
\hline
\end{tabular}


Table 6-2

Laboratory Chemical, Toxicity Characteristic Leaching Procedure, and Radiochemistry Analytical Requirements for Industrial Sites

(Page 3 of 4 )

\begin{tabular}{|c|c|c|c|c|c|c|}
\hline $\begin{array}{l}\text { Parameter or } \\
\text { Analyte }\end{array}$ & $\begin{array}{l}\text { Medium or } \\
\text { Matrix }\end{array}$ & $\begin{array}{l}\text { Analytical } \\
\text { Method }\end{array}$ & $\begin{array}{c}\text { Minimum Reporting } \\
\text { Limit }\end{array}$ & \begin{tabular}{|c|} 
RCRA Hazardous \\
Waste \\
Regulatory Limit
\end{tabular} & $\begin{array}{l}\text { Relative Percent } \\
\text { Different (RPD) }^{\mathrm{a}}\end{array}$ & $\begin{array}{c}\text { Percent Recovery } \\
(\% \mathrm{R})^{\mathrm{b}}\end{array}$ \\
\hline \multicolumn{7}{|c|}{ INORGANICS } \\
\hline \multicolumn{7}{|c|}{$\begin{array}{c}\text { Total Resource Conservation } \\
\text { and Recovery Act (RCRA) } \\
\text { Metals }\end{array}$} \\
\hline \multirow{2}{*}{ Cadmium } & Water & $6010 B^{c}$ & $5 \mu \mathrm{g} / \mathrm{L}^{\mathrm{h}, \mathrm{i}}$ & \multirow{12}{*}{ NA } & \multirow{12}{*}{$20^{\circ}$} & \multirow{12}{*}{$75-125^{i}$} \\
\hline & Soil & $6010 B^{c}$ & $0.5 \mathrm{mg} / \mathrm{kg}^{\mathrm{h}, \mathrm{i}}$ & & & \\
\hline \multirow{2}{*}{ Chromium } & Water & $6010 \mathrm{~B}^{\mathrm{c}}$ & $10 \mu \mathrm{g} / \mathrm{L}^{\mathrm{h}, \mathrm{i}}$ & & & \\
\hline & Soil & $6010 B^{c}$ & $1 \mathrm{mg} / \mathrm{kg}^{\mathrm{h}, \mathrm{i}}$ & & & \\
\hline \multirow{2}{*}{ Lead } & Water & $6010 B^{c}$ & $3 \mu \mathrm{g} / \mathrm{L}^{\mathrm{h}, \mathrm{i}}$ & & & \\
\hline & Soil & $6010 \mathrm{~B}^{\mathrm{c}}$ & $0.3 \mathrm{mg} / \mathrm{kg}^{\mathrm{h}, \mathrm{i}}$ & & & \\
\hline \multirow{2}{*}{ Mercury } & Water & $7470 A^{c}$ & $0.2 \mu \mathrm{g} / \mathrm{L}^{\mathrm{h}, \mathrm{i}}$ & & & \\
\hline & Soil & $7471 A^{c}$ & $0.1 \mathrm{mg} / \mathrm{kg}^{\mathrm{h}, \mathrm{i}}$ & & & \\
\hline \multirow{2}{*}{ Selenium } & Water & $6010 B^{c}$ & $5 \mu \mathrm{g} / \mathrm{L}^{\mathrm{h}, \mathrm{i}}$ & & & \\
\hline & Soil & $6010 B^{c}$ & $0.5 \mathrm{mg} / \mathrm{kg}^{\mathrm{h}, \mathrm{i}}$ & & & \\
\hline \multirow{2}{*}{ Silver } & Water & $6010 B^{c}$ & $10 \mu \mathrm{g} / \mathrm{L}^{\mathrm{h}, \mathrm{i}}$ & & & \\
\hline & Soil & $6010 \mathrm{~B}^{\mathrm{c}}$ & $1 \mathrm{mg} / \mathrm{kg}^{\mathrm{h}, \mathrm{i}}$ & & & \\
\hline Arsenic & \multirow{8}{*}{ Aqueous } & \multirow{8}{*}{$\begin{array}{l}1311 / 6010 \mathrm{~B}^{\mathrm{c}} \\
1311 / 7470 \mathrm{~A}^{\mathrm{c}}\end{array}$} & $0.10 \mathrm{mg} / \mathrm{L}^{\mathrm{h}, \mathrm{i}}$ & $5 \mathrm{mg} / \mathrm{L}^{\mathrm{f}}$ & \multirow{8}{*}{$20^{i}$} & \multirow{8}{*}{$75-125^{i}$} \\
\hline Barium & & & $2 \mathrm{mg} / \mathrm{L}^{\mathrm{h}, \mathrm{i}}$ & $100 \mathrm{mg} / \mathrm{L}^{f}$ & & \\
\hline Cadmium & & & $0.05 \mathrm{mg} / \mathrm{L}^{\mathrm{h}, \mathrm{i}}$ & $1 \mathrm{mg} / \mathrm{L}^{\mathrm{f}}$ & & \\
\hline Chromium & & & $0.10 \mathrm{mg} / \mathrm{L}^{\mathrm{h}, \mathrm{i}}$ & $5 \mathrm{mg} / \mathrm{L}^{\mathrm{f}}$ & & \\
\hline Lead & & & $0.03 \mathrm{mg} / \mathrm{L}^{\mathrm{h}, \mathrm{i}}$ & $5 \mathrm{mg} / \mathrm{L}^{\mathrm{f}}$ & & \\
\hline Mercury & & & $0.002 \mathrm{mg} / \mathrm{L}^{\mathrm{h}, \mathrm{i}}$ & $0.2 \mathrm{mg} / \mathrm{L}^{\mathrm{f}}$ & & \\
\hline Selenium & & & $0.05 \mathrm{mg} / \mathrm{L}^{\mathrm{h}, \mathrm{i}}$ & $1 \mathrm{mg} / \mathrm{L}^{\mathrm{f}}$ & & \\
\hline Silver & & & $0.10 \mathrm{mg} / \mathrm{L}^{\mathrm{h}, \mathrm{i}}$ & $5 \mathrm{mg} / \mathrm{L}^{\mathrm{t}}$ & & \\
\hline \multirow{2}{*}{ Cyanide } & Water & \multirow{2}{*}{$9010 \mathrm{~B}^{\mathrm{c}}$} & $0.01 \mathrm{mg} / \mathrm{L}^{i}$ & \multirow{2}{*}{ NA } & \multirow{2}{*}{$20^{i}$} & \multirow{2}{*}{$75-125^{i}$} \\
\hline & Soil & & $1.0 \mathrm{mg} / \mathrm{kg}^{\mathrm{i}}$ & & & \\
\hline \multirow[b]{2}{*}{ Sulfide } & Water & \multirow[b]{2}{*}{$9030 \mathrm{~B} / 9034^{\mathrm{C}}$} & $0.4 \mathrm{mg} / \mathrm{L}^{\mathrm{c}}$ & \multirow[b]{2}{*}{ NA } & \multirow[b]{2}{*}{ Lab-specific $^{9}$} & \multirow[b]{2}{*}{ Lab-specific $^{9}$} \\
\hline & $\begin{array}{c}\text { Soil or } \\
\text { Sediment }\end{array}$ & & $10 \mathrm{mg} / \mathrm{kg}^{\mathrm{h}}$ & & & \\
\hline \multirow{2}{*}{$\mathrm{pH} /$ Corrosivity } & Water & $9040 \mathrm{~B}^{\mathrm{c}}$ & \multirow{2}{*}{ NA } & see 40 CFR $261^{\dagger}$ & \multirow{2}{*}{ Lab-specific $^{9}$} & \multirow{2}{*}{ Lab-specific ${ }^{9}$} \\
\hline & Soil & $9045 C^{c}$ & & see 40 CFR $261^{f}$ & & \\
\hline \multirow{2}{*}{ Ignitability } & Water & $1010^{\circ}$ & NA & $\begin{array}{l}\text { Flash Point } \\
<140^{\circ} \mathrm{F}^{\mathrm{t}}\end{array}$ & NA & NA \\
\hline & Soil & $1030^{\circ}$ & & see 40 CFR $261^{\dagger}$ & & \\
\hline
\end{tabular}


Table 6-2

\section{Laboratory Chemical, Toxicity Characteristic Leaching Procedure, and Radiochemistry Analytical Requirements for Industrial Sites} (Page 4 of 4 )

\begin{tabular}{|c|c|c|c|c|c|c|}
\hline $\begin{array}{l}\text { Parameter or } \\
\text { Analyte }\end{array}$ & $\begin{array}{l}\text { Medium or } \\
\text { Matrix }\end{array}$ & $\begin{array}{l}\text { Analytical } \\
\text { Method }\end{array}$ & $\begin{array}{c}\text { Minimum Reporting } \\
\text { Limit }\end{array}$ & $\begin{array}{l}\text { RCRA Hazardous } \\
\text { Waste } \\
\text { Regulatory Limit }\end{array}$ & $\begin{array}{l}\text { Relative Percent } \\
\text { Different (RPD) }\end{array}$ & $\begin{array}{c}\text { Percent Recovery } \\
(\% \mathbf{R})^{\mathrm{b}}\end{array}$ \\
\hline \multicolumn{7}{|c|}{ RADIOCHEMISTRY } \\
\hline \multirow{2}{*}{$\begin{array}{l}\text { Gamma-emitting } \\
\text { Radionuclides }\end{array}$} & Water & \multirow{2}{*}{$\begin{array}{l}\text { EPA } 901.1^{k} \\
\text { HASL-300 }\end{array}$} & $10 \mathrm{pCi} / \mathrm{L}(\mathrm{Cs}-137)^{\mathrm{m}}$ & \multirow{2}{*}{ NA } & 20 & \multirow{10}{*}{$\begin{array}{c}\text { Laboratory Control } \\
\text { Sample Recovery } \\
80-120\end{array}$} \\
\hline & Soil & & $0.5 \mathrm{pCi} / \mathrm{g}(\mathrm{Cs}-137)^{\mathrm{m}}$ & & 35 & \\
\hline \multirow{2}{*}{$\begin{array}{c}\text { Isotopic } \\
\text { Plutonium }\end{array}$} & Water & \multirow{2}{*}{$\begin{array}{c}\text { HASL-300' } \\
\text { ASTM C104-90 }\end{array}$} & $0.1 \mathrm{pCi} / \mathrm{L}$ & \multirow{2}{*}{ NA } & 20 & \\
\hline & Soil & & $0.05 \mathrm{pCi} / \mathrm{g}$ & & 35 & \\
\hline \multirow{2}{*}{$\begin{array}{l}\text { Isotopic } \\
\text { Uranium }^{\mathrm{j}}\end{array}$} & Water & $\begin{array}{c}\text { HASL-300' } \\
\text { ASTM D3972-97n }\end{array}$ & $0.2 \mathrm{pCi} / \mathrm{L}$ & \multirow{2}{*}{ NA } & 20 & \\
\hline & Soil & $\begin{array}{c}\text { HASL-300' } \\
\text { ASTM E1000-90 }\end{array}$ & $0.1 \mathrm{pCi} / \mathrm{g}$ & & 35 & \\
\hline \multirow{2}{*}{ Strontium - 90 } & Water & ASTM D5811-95n & $1.0 \mathrm{pCi} / \mathrm{L}$ & \multirow{2}{*}{ NA } & 20 & \\
\hline & Soil & HASL-300' & $0.5 \mathrm{pCi} / \mathrm{g}$ & & 35 & \\
\hline \multirow{2}{*}{ Americium - $241^{j}$} & Water & HASL-300' & $0.1 \mathrm{pCi} / \mathrm{L}$ & NA & 20 & \\
\hline & Soil & HASL-300' & $0.05 \mathrm{pCi} / \mathrm{g}^{1}$ & NA & 35 & \\
\hline \multirow[b]{2}{*}{ Tritium } & Water & EPA $906.0^{k}$ & 400 & \multirow[b]{2}{*}{ NA } & 20 & \multirow{2}{*}{$\begin{array}{c}\text { Laboratory Control } \\
\text { Sample Recovery } \\
80-120 \% \\
\text { Matrix Spike } \\
\text { Recovery } 61-140 \% \\
\end{array}$} \\
\hline & Soil (Sludge) & PAI 754/704 & $1 \mathrm{pCi} / \mathrm{g}$ & & 20 & \\
\hline
\end{tabular}

${ }^{\text {a }}$ RPD is used to Calculate Precision

Precision is estimated from the relative percent difference of the concentrations measured for the matrix spike and matrix spike duplicate or of laboratory, or field duplicates of unspiked samples. It is calculated by: $R P D=100 \times\left\{\left(\left|C_{1}-C_{2}\right|\right) /\left(\left(C_{1}+C_{2}\right) / 2\right]\right\}$, where $C_{1}=$ Concentration of the analyte in the first sample aliquot, $\mathrm{C}_{2}=$ Concentration of the analyte in the second sample aliquot.

b \% R is used to Calculate Accuracy

Accuracy is assessed from the recovery of analytes spiked into a blank or sample matrix of interest, or from the recovery of surrogate compounds spiked into each sample. The recovery of each spiked analyte is calculated by: $\% R=100 \times\left(C_{s}-C_{u} / C_{n}\right)$, where $C_{s}=$ Concentration of the analyte in the spiked sample, $C_{u}=$ Concentration of the analyte in the unspiked sample, $C_{n}=$ Concentration increase that should result from spiking the sample - U.S. Environmental Protection Agency (EPA) Test Methods for Evaluating Solid Waste, 3rd Edition, Parts 1-4, SW-846 CD ROM Washington, DC (EPA, 1996)

${ }^{d}$ Estimated Quantitation Limit as given in SW-846 (EPA, 1996)

e EPA Contract Laboratory Program Statement of Work for Organic Analysis (EPA, 1988b; 1991; and 1994c)

' Title 40 Code of Federal Regulations Part 261 "Identification and Listing of Hazardous Waste" (CFR, 2000)

9 In-House Generated RPD and \%R Performance Criteria

It is necessary for laboratories to develop in-house performance criteria and compare them to those in the methods. The laboratory begins by analyzing 15-20 samples of each matrix and calculating the mean \%R for each analyte. The standard deviation (SD) of each \%R is then calculated, and the warning and control limits for each analyte are established at \pm 2 SD and \pm 3 SD from the mean, respectively. If the warning limit is exceeded during the analysis of any sample delivery group (SDG), the laboratory institutes corrective action to bring the analytical system back into control. If the control limit is exceeded, the sample results for that SDG are considered unacceptable. These limits are reviewed after every quarter and are updated when necessary. The laboratory tracks trends in both performance and control limits by the use of control charts. The laboratory's compliance with these requirements is confirmed as part of an annual laboratory audit. Similar procedures are followed in order to generate acceptance criteria for precision measurements

" Industrial Sites Quality Assurance Project Plan (DOE/NV, 1996)

'EPA Contract Laboratory Program Statement of Work for Inorganic Analysis (EPA, 1988a; 1994b; and 1995)

${ }^{\prime}$ Isotopic minimum detectable concentrations are defined during the DQO process and specified in the CAIP as applicable

${ }^{k}$ Prescribed Procedures for Measurements of Radioactivity in Drinking Water, EPA-600/4-80-032 (EPA, 1980)

' Manual of Environmental Measurements Laboratory Procedures, HASL-300 (DOE, 1997)

m Since each gamma emitter has a unique detection limit, the measurement sensitivity will be specified relative to Cs-137.

${ }^{n}$ American Society for Testing and Materials

- Laboratory specific method (PAI, 1999)

Definitions:

$\mu \mathrm{g} / \mathrm{kg}=$ Microgram(s) per kilogram

$\mathrm{mg} / \mathrm{kg}=$ Milligram(s) per kilogram

$\mathrm{pCi} / \mathrm{L}=$ Picocurie $(\mathrm{s})$ per liter

$\mathrm{mg} / \mathrm{L}=$ Milligram(s) per liter

$\mathrm{pCi} / \mathrm{g}=$ Picocurie(s) per gram

$\mu \mathrm{g} / \mathrm{L}=$ Microgram(s) per liter 


\subsection{References}

Adams, S., IT Corporation. 2000. Memorandum to B. Bailey (IT Corporation) entitled, "Radiological Contaminants of Potential Concern in Nevada Test Site Mud Pits," 30 November. Las Vegas, NV.

AEC, see Atomic Energy Commission.

Atlan-Tech. 1992. Environmental Monitoring Report for the Proposed Ward Valley, California, LLRW Facility. Rosewall, GA.

BN, see Bechtel Nevada.

Bechtel Nevada. 1995. Nevada Test Site Performance Objective for Certification of Nonradioactive Hazardous Waste, G-E11/96.01, Rev. 0. Las Vegas, NV.

Bechtel Nevada. 2001. Electronic MicroStation map entitled "Technical Site Information Site Plan Area 3 Base Camp," as presented to ITLV on 21 March. Las Vegas, NV.

Black, S.C. and Y.E. Townsend. 1996. U.S. Department of Energy Nevada Operations Office Environmental Data Report for the Nevada Test Site - 1994.

Bordelois, B., Science Applications International Corporation. 1998a. Memo to R. Jackson (IT Corporation) entitled, "CAU 356, CAS 03-09-01 Sampling Report," 24 March. Las Vegas, NV.

Bordelois, B., Science Applications International Corporation. 1998b. Memo to R. Jackson (IT Corporation) entitled, "CAU 356, CAS 03-09-03 Sampling Report," 20 March. Las Vegas, NV.

Bordelois, B., Science Applications International Corporation. 1998c. Memo to R. Jackson (IT Corporation) entitled, "CAU 356, CAS 03-09-04 Sampling Report," 9 April. Las Vegas, NV.

Bull, R., Science Applications International Corporation. 2001. Memorandum to D. Arnold (SAIC) entitled, "Preliminary Assessment Data for CAU 356," 11 June. Las Vegas, NV: IT Corporation.

Butler, M., Lawrence Livermore National Laboratory. 2000. Record of Telecon with B. Bailey (IT) concerning the mud pits on the NTS, 2 November. Las Vegas, NV.

CFR, see Code of Federal Regulations. 
Code of Federal Regulations. 1999a. 40 CFR 265.172, "Compatibility of Waste with Containers." Washington, DC: U.S. Government Printing Office.

Code of Federal Regulations. 1999b. 40 CFR 265.177, "Special Requirements for Incompatible Waste." Washington, DC: U.S. Government Printing Office.

Code of Federal Regulations. 1999c. 49 CFR 178, "Specifications for Packagings."

Washington, DC: U.S. Government Printing Office.

Code of Federal Regulations. 2000. 40 CFR Part 261, "Identification and Listing of Hazardous Waste." Washington, DC: U.S. Government Printing Office.

DOE, see U.S. Department of Energy.

DOE/NV, see U.S. Department of Energy, Nevada Operations Office.

DRI, see Desert Research Institute.

Desert Research Institute. 1988. CERCLA Preliminary Assessment of DOE's Nevada Operations Office Nuclear Weapons Testing Areas, Volume I. Prepared for U.S. Department of Energy, Nevada Operations Office. Las Vegas, NV: Water Resources Center.

Desert Research Institute. 1996. Nevada Test Site Water-Supply Wells, DOE/NV10845--86.

Prepared by D. Gillespie, D. Jonathan, and P. Seaber. Reno, NV: Water Resources Center.

EPA, see U.S. Environmental Protection Agency.

FFACO, see Federal Facility Agreement and Consent Order.

Federal Facility Agreement and Consent Order. 1996 (as amended). Agreed to by the State of Nevada, the U.S. Department of Energy, and the U.S. Department of Defense.

Flangas, W.G., Reynolds Electrical \& Engineering Co., Inc. 1990. Letter to J. Stewart (DOE/NV) entitled, "Area 3 Septic System," 5 January. Las Vegas, NV.

Flangas, W.G., Reynolds Electrical \& Engineering Co., Inc. 1992. Letter to J.D. Steward (DOE/NV) entitled, "Research New Drill Mud Disposal Sites," 4 November. Mercury, NV.

Forsgren, F., HSI GeoTrans Inc. 1998. Memorandum to R. Jackson (IT Corporation) entitled: "CAU 356, CAS 03-09-05, Sampling Report," 14 April. Las Vegas, NV.

H\&N, Inc., see Holmes and Narver, Inc.

Haworth, O., Reynolds Electrical \& Engineering Co., Inc. 1990a. Letter to J. Stewart (DOE/NV) entitled, "Area 3 Septic System Modification Information," 16 February. Las Vegas, NV. 
Haworth, O., Reynolds Electrical \& Engineering Co., Inc. 1990b. Letter to F. Huckabee (DOE/NV) entitled, "Area 3 Septic System," 6 October. Las Vegas, NV.

Haworth, O., Reynolds Electrical \& Engineering Co., Inc. 1991. Letter to D. Watson (DOE/NV) entitled, "Area 3 Sewage Systems Options," 29 January. Las Vegas, NV.

Haworth, O., Bechtel Nevada. 2000. Record of Telecon with J. Markowsky and T. Renninger (SAIC) concerning the Area 3 Change House Septic System, 13 November. Las Vegas, NV: IT Corporation.

Holmes \& Narver, Inc. 1962. Engineering drawing JS-003-096-M8.1, entitled, "Skid Mounted Machine Shop Mechanical Plan \& Section," 24 January. Mercury, NV: Archives and Records Center.

Holmes \& Narver, Inc. 1966. Engineering drawing, JS-020-U20b-C1, "Surface Facilities Site Plan." Mercury, NV: Archives and Records Center.

Holmes \& Narver, Inc. 1971. Engineering drawing JS-003-820-S8.2, entitled, "LASL Machine Shop Addition Floor Plan \& Details," 10 September. Las Vegas, NV.

Holmes \& Narver, Inc. 1972. Engineering drawing JS-003-U3gi-C1.2, "Station U3gi Surface Facilities Site Plan.” Mercury, NV: Archives and Records Center.

Holmes \& Narver, Inc. 1982a. Engineering drawing JS-003-3C-35-P1.1, entitled, "REECo Office Complex-Bldg. 3C-35 Drain \& Water System Plan \& Isometric," 21 February. Las Vegas, NV.

Holmes \& Narver, Inc. 1982b. Engineering drawing JS-003-3C-32-FP2, entitled, "H\&N Office Complex-3C-32, Remodeled Floor Plan," 28 April. Las Vegas, NV.

Holmes \& Narver, Inc. 1984. Engineering drawing JS-003-U31y-C1, "Nevada Test Site - Area 3 Los Alamos Station - U3ly Surface Facilities Drilling Site Plan.” Mercury, NV: Archives and Records Center.

Holmes \& Narver, Inc. 1988. Engineering drawing JS-003-054-C1, entitled, "Area 3 Camp Facilities Water and Sewer Distribution,” 12 September. Las Vegas, NV.

Holmes \& Narver, Inc. 1992. Engineering drawing JS-090-094-C30, "Drill Hole Planning Map Areas 1, 3, 4, 6, \& 7 Current Status as of 4-1-92," 1 April. Mercury, NV: Archive and Records Center.

Holmes \& Narver, Inc. Unknown date. Engineering drawing entitled, "Area 3 Camp Vicinity." Las Vegas, NV.

IT, see IT Corporation. 
IT Corporation. 1997. Sample Collection Logs for CAS 03-09-01, 19 August. Las Vegas, NV.

IT Corporation. 2000. Health and Safety Plan, ITLV 13052--105. Las Vegas, NV.

IT Corporation. 2001. Field Activity Daily Log from a field visit to sites in CAU 356, 13 March. Las Vegas, NV.

LANL, see Los Alamos National Laboratory.

Liebendorfer, P.J., Nevada Department of Environmental Protection. 2001. Letter to R. Wycoff (NNSA/NV) entitled, "Proposed Modification for CAU 356: Mud Pits \& Disposal Sites, Transfer of CAS 20-22-01 from CAU 352 to CAU 356 Federal Facilities Agreement and Consent Order," 30 May. Las Vegas, NV.

Los Alamos National Laboratory. 1991. Survey of Hazardous Materials Used in Nuclear Testing. Prepared by E.A. Bryant and J. Fabryka-Martin. Los Alamos, NM.

Magruder, J.K., U.S. Department of Energy, Nevada Operations Office. 1991. Letter to H.W. Dickson (REECo) entitled, "Inactive Sites Inventory," 6 August. Las Vegas, NV.

Marshall, D., Bechtel Nevada. 2001a. Interview with A. Dudley (SAIC) concerning Area 3 Camp facilities, 28 March. Las Vegas, NV.

Marshall, D., Bechtel Nevada. 2001b. Interview with A. Dudley (SAIC) concerning Area 3 Camp facilities, 29 March. Las Vegas, NV.

McArthur, R.D., and F.L. Miller. 1989. Off-Site Radiation Exposure Review Project (ORERP), Phase II Soil Program, DOE/NV/10384-23. Las Vegas, NV: Desert Research Institute.

Moore, J. 1999. Memorandum to M. Todd (SAIC), entitled "Background Concentrations for NTS and TTR Soil Samples," 3 February. Las Vegas, NV: IT Corporation.

NAC, see Nevada Administrative Code.

NBMG, see Nevada Bureau of Mines and Geology.

Nevada Administrative Code. 2000a. NAC 444, "Sanitation.” Carson City, NV.

Nevada Administrative Code. 2000b. NAC 444.570 - 444.7499, "Solid Waste Disposal." Carson City, NV.

Nevada Administrative Code. 2000c. NAC 444.850 - 444.8746, "Disposal of Hazardous Waste." Carson City, NV. 
Nevada Administrative Code. 2000d. NAC 445A.2272, "Contamination of Soil: Establishment of Action Levels." Carson City, NV.

Nevada Administrative Code. 2000e. NAC 459.9973, "Hazardous Materials, Storage Tanks.” Carson City, NV.

Nevada Bureau of Mines and Geology. 1998. Mineral and Energy Resource Assessment of the Nellis Air Force Range, Open-File Report 98-1. Reno, NV.

NRS, see Nevada Revised Statutes.

Nevada Revised Statutes. 1999a. NRS 444.440 - 444.620, "Collection and Disposal of Solid Waste." Carson City, NV.

Nevada Revised Statutes. 1999b. NRS 459.400 - 459.600, "Disposal of Hazardous Waste." Carson City, NV.

PAI, see Paragon Analytics, Inc.

Paragon Analytics, Inc. 1999. "Analysis of Tritium and Other Beta-Emitting Nuclides by Liquid Scintillarion Counting," SQP 704, Rev. 5. Fort Collins, CO.

RSN, see Raytheon Services Nevada.

Racine, B., Mercury Blue Print \&Supply Co. 2001. Interview with A. Dudley (SAIC) concerning blue printing chemicals, 28 March. Las Vegas, NV.

Raytheon Services Nevada. 1991. Nevada Test Site Drilling \& Mining Summary. Prepared for U.S. Department of Energy, Nevada Operations Office. Las Vegas, NV.

Raytheon Services Nevada. 1995. Engineering drawing, SK-003-95-C86, "Environmental Concerns 201-233." Mercury, NV: Archives and Records Center.

REECo, see Reynolds Electrical \& Engineering Co., Inc.

Reynolds Electrical \& Engineering Co., Inc. 1967. Engineering drawing, 3-C5, "Support Facilities As Built." Mercury, NV: Archives and Records Center.

Reynolds Electrical \& Engineering Co., Inc. 1990. Engineering drawing, 3-SL-C3, "Modification Area 3 Camp Sewage Facility Site Plan.” Las Vegas, NV.

Reynolds Electrical \& Engineering Co., Inc. 1993. "REECo Environmental Compliance Department NTS Permit Status: 06/13/93,” 10 June. Las Vegas, NV. 
Reynolds Electrical \& Engineering Co., Inc. 1994. Area 3 Waste Impoundment - Historical Information. Prepared by C.G. Postle. Las Vegas, NV.

Reynolds Electrical \& Engineering Co., Inc. 1995. Preliminary Characterization of Abandoned Septic Tank Systems, DOE/NV--414. Las Vegas, NV.

Rowe, P., Stone and Webster Incorporated. 2000. Record of telecon with J. Markowsky (SAIC) concerning Area 3, Mud Disposal Crater, 18 December. Las Vegas, NV.

Rowe, P., Stone and Webster Incorporated. 2001. Record of Telecon with Beatriz Bordelois (SAIC) concerning mud pits and cellars/sumps, 22 January. Las Vegas, NV.

Rogers, A., Los Alamos National Laboratory (retired). 2001. Interview with A. Dudley (SAIC) concerning the Area 3 Camp Machine Shop, 2 April. Las Vegas, NV.

U.S. Department of Energy. 1996. Safety Management Policy, DOE P 450.4. Washington, DC.

U.S. Department of Energy. 1997. Environmental Measurements Laboratory Procedures Manual, HASL-300, 28th Edition, Vol. 1. New York, NY.

U.S. Department of Energy, Nevada Operations Office. 1994. Project Management Plan, Rev. 0. Las Vegas, NV.

U.S. Department of Energy, Nevada Operations Office. 1995a. Area 3 Base Camp Closure Demolition and Environmental Total Estimated Cost. Las Vegas, NV.

U.S. Department of Energy, Nevada Operations Office. 1995b. Preliminary Ranking and Prioritization - DOE Defense Programs Sites at NTS. Prepared by P. Sanders. Las Vegas, NV.

U.S. Department of Energy, Nevada Operations Office. 1996a. Final Environmental Impact Statement for the Nevada Test Site and Off-site Locations in the State of Nevada, DOE/EIS 0243. Las Vegas, NV.

U.S. Department of Energy, Nevada Operations Office. 1996b. Industrial Sites Quality Assurance Project Plan, DOE/NV--372. Las Vegas, NV.

U.S. Department of Energy, Nevada Operations Office. 1998. Work Plan for Leachfield Corrective Action Units: Nevada Test Site and Tonopah Test Range, Nevada, Rev. 1, DOE/NV--514. Las Vegas, NV.

U.S. Department of Energy, Nevada Operations Office. 1999a. Corrective Action Decision Document/Closure Report for Corrective Action Unit 266: Area 25 Building 3124 Leachfield, Nevada Test Site, Nevada, Rev. 0, DOE/NV--577. Las Vegas, NV. 
U.S. Department of Energy, Nevada Operations Office. 1999b. Corrective Action Decision Document for Corrective Action Unit 261: Area 25 Test Cell A Leachfield System, Nevada Test Site, Nevada, Rev. 0, DOE/NV--583. Las Vegas, NV.

U.S. Department of Energy, Nevada Operations Office. 1999c. Corrective Action Decision Document for Corrective Action Unit 417: Central Nevada Test Area Surface, Nevada, Rev. 1, DOE/NV-524-APBD, April. Las Vegas, NV.

U.S. Department of Energy, Nevada Operations Office. 1999d. Nevada Environmental Restoration Project, Salmon Site Remedial Investigation Report. Las Vegas, NV.

U.S. Department of Energy, Nevada Operations Office. 2000a. Corrective Action Decision Document for Corrective Action Unit 428: Area 3 Septic Systems 1 and 5, Tonopah Test Range, Nevada, Rev. 0, DOE/NV--587. Las Vegas, NV.

U.S. Department of Energy, Nevada Operations Office. 2000b. Nevada Test Site Waste Acceptance Criteria (NTSWAC), Rev. 3. Las Vegas, NV.

U.S. Department of Energy, Nevada Operations Office. 2000c. United States Nuclear Tests, July 1945 through September 1992, Rev. 15, DOE/NV-209. Las Vegas, NV.

U.S. Environmental Protection Agency. 1980. Prescribed Procedures for Measurements of Radioactivity in Drinking Water, EPA-600/4-79-020. Washington, DC.

U.S. Environmental Protection Agency. 1988a. Contract Laboratory Program Statement of Work for Inorganic Analysis, SOW No. 788, EPA/540/R-94/093. Washington, DC.

U.S. Environmental Protection Agency. 1988b. Contract Laboratory Program Statement of Work for Organic Analysis, SOW No. 2/88, EPA/540/R-94//096. Washington, DC.

U.S. Environmental Protection Agency. 1991. Contract Laboratory Program Statement of Work for Organic Analysis, OLMO 1.8, EPA/540/R-94/078. Washington, DC.

U.S. Environmental Protection Agency. 1994a. Contract Laboratory Program National Functional Guidelines for Inorganic Data Review, EPA 540/R-94/013. Washington, DC.

U.S. Environmental Protection Agency. 1994b. Contract Laboratory Program Statement of Work for Inorganic Analysis, ILMO 3.0, EPA/540/R-94/076. Washington, DC.

U.S. Environmental Protection Agency. 1994c. Contract Laboratory Program Statement of Work for Organic Analysis, OLMO 3.1, EPA/540/R-94/073. Washington, DC.

U.S. Environmental Protection Agency. 1995. Contract Laboratory Program Statement of Work for Inorganic Analysis, ILMO 4.0, EPA/540/R-95/121. Washington, DC. 
U.S. Environmental Protection Agency. 1996. Test Methods for Evaluating Solid Waste, Physical/Chemical Methods, SW-846, $3^{\text {rd }}$ Edition (which includes updates to 1986, 1992, and 1994 revisions), CD-ROM PB97-501928GEI. Washington, DC.

U.S. Environmental Protection Agency. 1999. Contract Laboratory Program National Functional Guidelines for Organic Data Review, EPA 540/R-99/008. Washington, DC.

U.S. Environmental Protection Agency. 2000. Memorandum from S.J. Smucker to PRG table mailing list regarding Region 9 Preliminary Remediation Goals (PRGs), 1 October.

San Francisco, CA.

USGS, see U.S. Geological Survey.

U.S. Geological Survey. 1969. Summary Geologic Report on the U20b Emplacement Hole, Pahute Mesa, Nevada Test Site, SS-80, USGS-474-35. Denver, CO.

U.S. Geological Survey. 1970. Report of Exploration Progress, Pahute Mesa, January 31, 1968 October 1, 1969, SS-I-23-17, USGS-474-70. Denver, CO.

U.S. Geological Survey. 1973. Geohydrology of the Eastern part of Pahute Mesa, Nevada Test Site, Nye County, Nevada, USGS Professional Paper 712-B. Prepared by R.K. Blankennagel and J.E. Weir, Jr. U.S. Geological Survey: Denver, CO.

Watson, D., U.S. Department of Energy. 1990. Letter to O. Haworth (REECo) entitled, "Area 3 Septic System,” 23 August. Las Vegas, NV.

Wilkes, M., Bechtel Nevada. 2000a. Record of meeting with B. Bailey (IT) regarding mud pits at the NTS, 3 November. Las Vegas, NV.

Wilkes, M., Bechtel Nevada. 2000b. Record of meeting with B. Bailey (IT) regarding mud pits at the NTS, 9 November. Las Vegas, NV.

Witt, J., Science Applications International Corporation. 2000a. Record of meeting with B. Bailey (IT) concerning mud pit usage, 19 October. Las Vegas, NV.

Witt, J., Science Applications International Corporation. 2000b. Record of meeting with K. Sculthorpe (SAIC) concerning mud pits, 9 November. Las Vegas, NV.

Wuellner, J.W., Reynolds Electrical \& Engineering Co., Inc. 1994. Memorandum to J.R. Bielawski (REECo) entitled, "Historical Information, Area 3 Waste Mud Impoundment," 2 May.

Las Vegas, NV. 


\section{Appendix A}

\section{Data Quality Objectives Worksheets}




\section{A.1.0 DQO Overview}

The DQO process is a strategic planning approach based on the scientific method that is used to prepare for a site characterization data collection activity (EPA, 2000a). The DQOs are designed to ensure that the data collected will provide sufficient and reliable information to identify, evaluate, and technically defend the chosen corrective action. Because the investigation of CAU 356 will occur in two phases, separate DQOs for each phase have been developed. Step 1, State the Problem, has elements common to both phases of the investigation; therefore, Step 1 will not be repeated for each phase. The remaining Steps 2 through 7 will be specific to each phase.

There is sufficient information and process knowledge from similar sites about the nature and extent of contamination at the six CASs to recommend closure of CAU 356 using the SAFER plan process (FFACO, 1996). The CAU 356 investigation will be based on the DQOs developed by representatives of NDEP and National Nuclear Security Administration Nevada Operations Office (NNSA/NV). Phase I of this investigation will determine if COPCs are present in concentrations exceeding PALs. If COPCs are present above PALs, a Phase II investigation will be implemented to determine the extent of contamination to support a corrective action alternative for closure.

\section{A.1.1 DQO Planning Team}

The DQO planning team for the FFACO-required DQO Kickoff Meeting consists of representatives from ITLV, NNSA/NV, Bechtel Nevada (BN), and NDEP. Table A.1-1 lists the representatives from each organization in attendance for the May 8, 2001, meeting. The primary decision makers include representatives from NNSA/NV and NDEP. Decision makers will receive notifications as work progresses and when decision points are reached within the SAFER process.

\section{A.1.2 Background}

Six CASs comprise CAU 356, Mud Pits and Disposal Sites. Five of the sites are located within Area 3 of the NTS, while the sixth site is located in Area 20. The six CASs are:

- CAS 03-04-01, Area 3 Change House Septic System

- CAS 03-09-01, Mud Pit Spill Over

- CAS 03-09-03, Mud Pit 
Table A.1-1

DQO Meeting Participants

\begin{tabular}{|c|c|c|}
\hline \multirow{2}{*}{ Participant } & \multirow{2}{*}{ Affiliation } & Meeting Date \\
\hline & & $\begin{array}{l}\text { Meeting } \\
05 / 08 / 2001\end{array}$ \\
\hline Dawn Arnold & ITLV & $x$ \\
\hline Rob Boehlecke & ITLV & $\mathrm{x}$ \\
\hline Kevin Cabble & NNSA/NV & $x$ \\
\hline Wolf Exner & ITLV & $x$ \\
\hline Thomas Fitzmaurice & $\mathrm{BN}$ & $\mathrm{x}$ \\
\hline Terrylynn Foley & ITLV & $x$ \\
\hline Syl Hersh & ITLV & $x$ \\
\hline Boyd Imai & ITLV & $x$ \\
\hline Brad Jackson & $\mathrm{BN}$ & $x$ \\
\hline Jeff Johnson & ITLV & $x$ \\
\hline R. Lynn Kidman & ITLV & $x$ \\
\hline Jodi Markowsky & ITLV & $x$ \\
\hline Mike McKinnon & NDEP & $x$ \\
\hline Steve Nacht & $\mathrm{BN}$ & $x$ \\
\hline Greg Raab & NDEP & $x$ \\
\hline Jeff Smith & $\mathrm{BN}$ & $x$ \\
\hline Julie Snelling-Young & ITLV & $x$ \\
\hline Milinka Watson-Garrett & ITLV & $\mathrm{x}$ \\
\hline Jeanne Wightman & ITLV & $x$ \\
\hline Lowell Wille & ITLV & $\mathrm{x}$ \\
\hline John Wong & NDEP & $\mathrm{x}$ \\
\hline
\end{tabular}

BN - Bechtel Nevada

NNSA/NV - National Nuclear Security Administration Nevada Operations Office

ITLV - IT Corporation, Las Vegas Office

NDEP - Nevada Division of Environmental Protection 
- CAS 03-09-04, Mud Pit

- CAS 03-09-05, Mud Pit

- CAS 20-16-01, Landfill

- CAS 20-22-21, Drums

The May 8, 2001, DQO meeting provided brief descriptions of each CAS to acquaint the planning team with the environmental problem identified at CAU 356 (copies of the presentation are available in project files). Background data for each CAS is provided in more detail in Section 2.0 of the SAFER Plan. Existing references that were reviewed and are the primary source for the background information are provided in Section 7.0 of the SAFER Plan and Section A.4.0.

\section{A.1.3 Conceptual Site Model}

The historical background information provided in the DQO meeting and Section 2.0 of the SAFER Plan were used to develop CSMs for CAU 356. The CSM describes the most probable scenario for current conditions at each site and defines the assumptions that are the basis for identifying appropriate sampling strategy and data collection methods. An accurate conceptual site model is important as it serves as the basis for all subsequent inputs and decisions throughout the DQO process. Two separate CSMs have been developed for CAU 356: one CSM for the septic system and a second model that describes the mud pits and mud disposal landfill.

\section{A.1.3.1 CSM for Mud Pits and Landfill}

The basis for developing this CSM was process knowledge and historical records. Figures A.1-1 and A.1-2 show a generalized representation of the CSM constructed for the mud pits and the mud disposal landfill, respectively. These diagrams show known and suspected locations of contaminants and potential pathways for physical transport. The following text accompanies the CSM diagram in relating information and assumptions that are used in developing the CSM:

- The COPCs, if present, are associated with the (1) disposal of used drilling mud and wastewater in the mud pits and mud disposal landfill, and (2) potential effluent discharge from truck dumping activities. Mud and subsurface soils are the affected media within each mud pit and the mud disposal landfill. The volume of any particular contaminant in the drilling fluid effluent is unknown.

- Potential contaminants listed below are associated with the discharged effluent into the mud pits: 


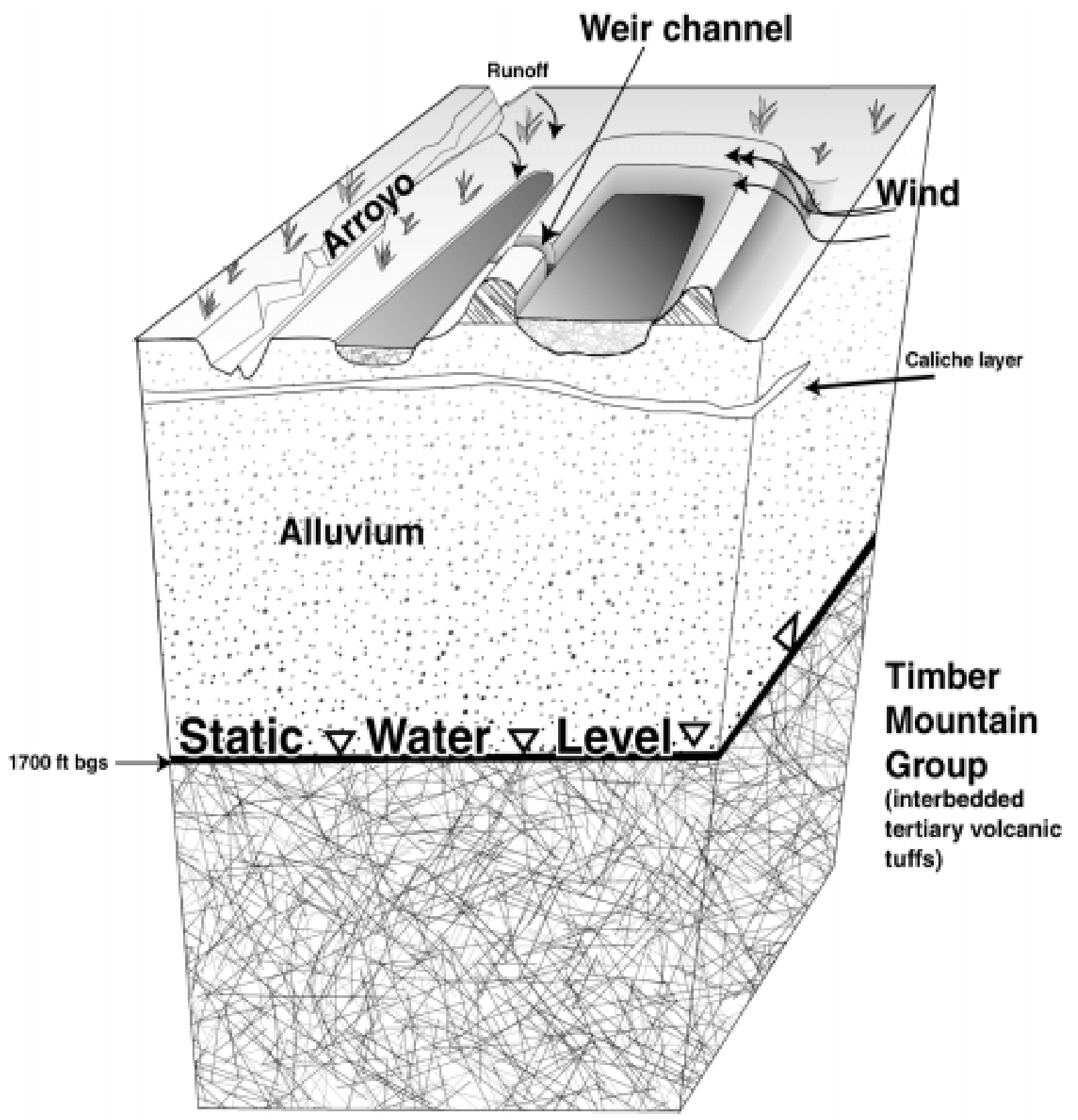

Note: Static water level and actual depth to

Timber Mountain Group estimated (DRI, 1988,1996)

Figure A.1-1

Conceptual Site Model for Mud Pits 


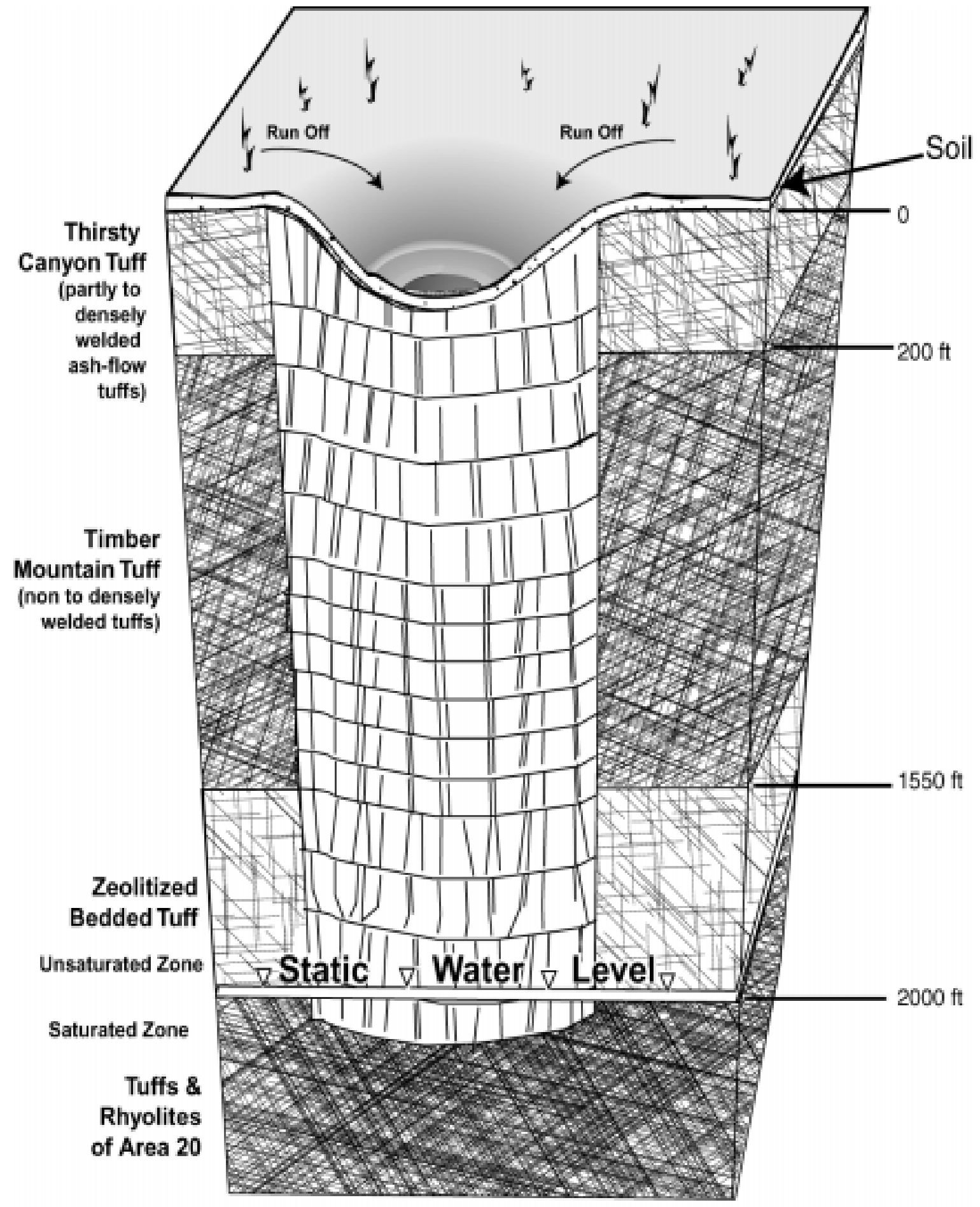

Source: USGS, 1969 and 1970

Figure A.1-2 
- Additives (e.g., polymers, chelating agents, diesel) used in mud and drilling fluids during drilling activities (LANL, 1991; Wuellner, 1994; Rowe, 2001).

- Fuels, grease, motor oil, and hydraulic fluids are compounds that may have leaked from trucks and discharged into the mud pit effluent stream (Wilkes, 2000a; Witt, 2000a).

- Radionuclide contamination is not expected at these CASs based on historical information; however, the potential still exists based on process knowledge of the activities conducted in Area 3 and Area 20 of the NTS (i.e., underground nuclear testing). The primary radioisotopes that could be expected, if present, are cesium-137, tritium, and strontium-90 (Adams, 2000).

- Diesel within drilling muds is expected to be the primary COPC with the greatest potential for concentrations above action levels, based on interviews (Wilkes, 2000a; Witt, 2000a) and process knowledge gained from similar investigations of mud pits (e.g., CNTA) (DOE/NV, 1999c and 1999d). Random dumping of constituents is considered minimal.

- Recirculation processes within the mud pits enhance volatilization of VOCs, thereby reducing the potential concentrations of any VOCs that may be present.

- 1997 sample results at the four mud pit CASs indicated detections of VOCs, SVOCs, RCRA metals, TPH, and radionuclides. None of the results exceeded action levels or background, except for arsenic which was above action levels but within NTS background levels (Bordelois, 1998a,b, and c; Forsgren, 1998).

- While contaminants within a system may be present at locations throughout the system, they will tend to be present in higher concentrations at particular locations within the system based on distinguishing physical characteristics of the contaminants. For example, petroleum-based fuels in the mud slurry would tend to be found in higher concentrations near the surface and lower concentrations near the bottom of the mud pits (DOE/NV, 1997). Other distinguishing characteristics of contaminants such as high or low solubility, high or low density, and large or small particle size can also be used to draw inferences on the locations within the mud pit system where they could be expected to be present at higher concentrations. Sampling in these preferential locations will increase the probability of detecting contamination if contamination is present anywhere within the system. The following four areas represent the preferential locations within the mud pit system:

- Near the surface and near the influent (recharge) location

- At the bottom of the pit near the influent location

- Near the surface at the lowest surface elevation

- At the lowest elevation of the pit bottom 
- Infiltration of COPCs are assumed to be limited to less than $10 \mathrm{ft}$ vertically and $5 \mathrm{ft}$ laterally based on past investigations of several mud pits (DOE/NV, 1999c and 1999d).

- It is assumed that the mud pits and the mud disposal landfill are not lined with an engineered liner. In the absence of a physical barrier below the mud, downward vertical migration will predominant over lateral migration. However, bentonite clay has a low hydraulic conductivity and a high adsorption capacity which binds constituents and inhibits migration into subsurface soils. Bentonite clay is commonly used as a pond liner to prevent infiltration of water into underlying units. Vertical migration is also currently limited because the mud pits are dry and potential evaporation exceeds precipitation.

- The densely welded volcanic tuff units that underlie the crater mud pit (see Figure A.1-1) tend to be highly fractured with increased transmissivity (USGS, 1970 and 1973). The underground nuclear test (i.e., Pipkin) conducted at U20b induced additional fracturing of these units and a surface crater. These densely welded tuffs provide preferential pathways to groundwater; however, there are factors that inhibit the migration of any COCs present in the mud to groundwater. The highly adsorptive nature of mud (i.e., bentonite) binds the contaminant and inhibits the migration of constituents as previously discussed in this CSM; also, bentonite is commonly used as natural pond liners to prevent infiltration, and would create seals within fractures underlying the mud limiting infiltration of precipitation.

- Contamination, if present, confined laterally to the historical and physical boundaries of each site such as the berms of each mud pit or the U20B crater. Lateral contamination of the mud spill at CAS 03-09-01 is not expected to extend past the edge of the visible mud layer. Primarily unsaturated conditions due to arid climate limit the potential for lateral migration into surrounding soils.

\section{A.1.3.2 Septic System CSM}

The basis for developing this CSM was process knowledge and historical records. Historical information indicates this CAS follows the general conceptual site model described in the Leachfield Work Plan. Figure A.1-3 shows a generalized representation of the CSM constructed for the septic system. This diagram shows known and suspected locations of contaminants and potential pathways for physical transport. The following text accompanies the CSM diagram in relating information and assumptions that are used in developing the CSM:

- The affected media are liquid and sludge/sediment within distribution structures, and surface and subsurface soils in proximity of the collection and distribution lines. The sources and types of potential constituents into the septic system effluent are:

- Sanitary waste from restroom facilities located within identified source buildings. 


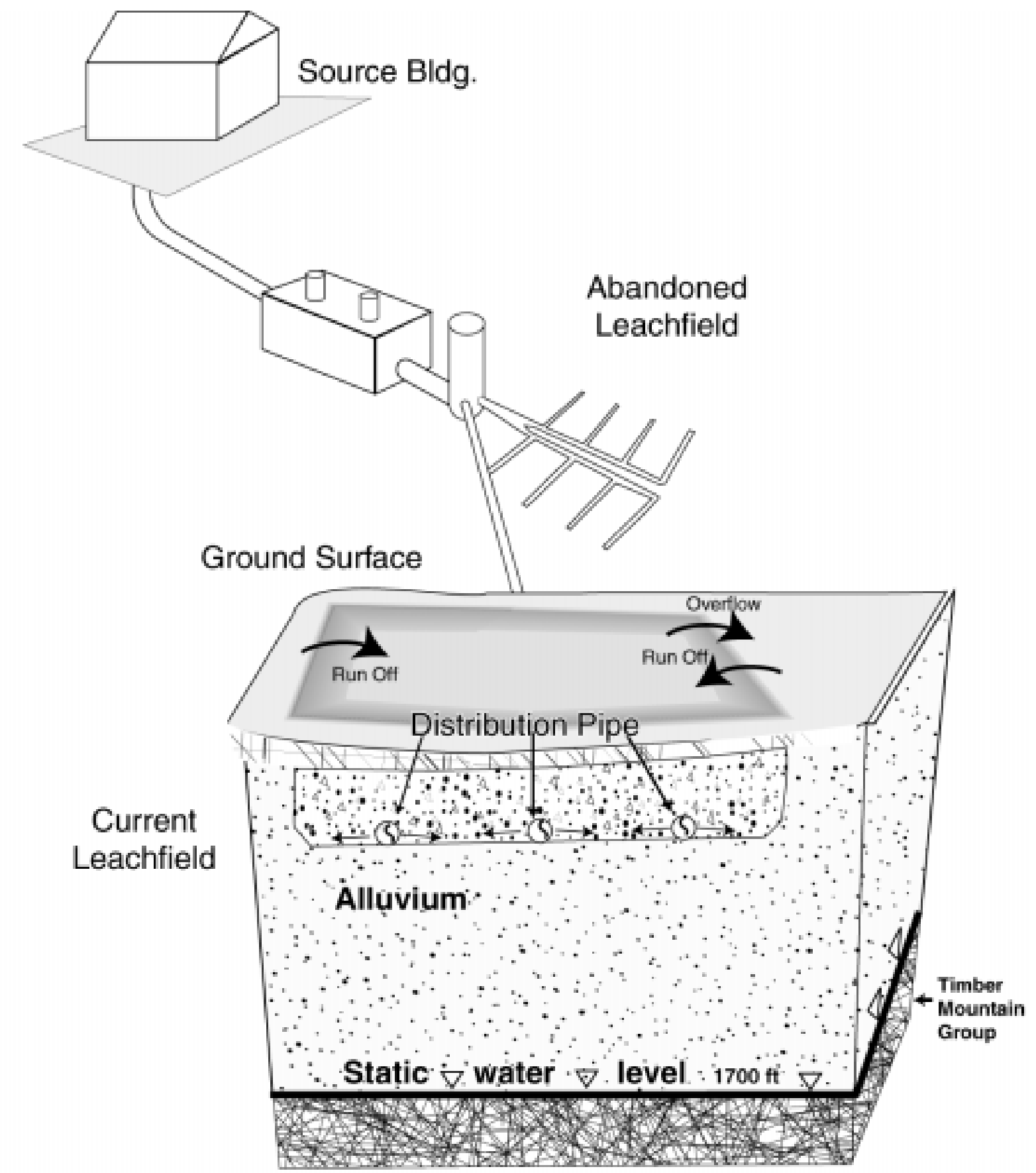

Note: Static water level and actual depth to Timber

Mountain Group estimated (DRI, 1988 and 1996) 
- Copper, aluminum, lead cuttings, lead paint, cutting oils, degreasers and solvents used in the Machine Shop and Storage facilities (H\&N, 1988; Marshall 2001a and 2001b; REECo, 1967; Rogers, 2001).

- Liquid ammonia from blueprinting activities (RSN 1995; Racine, 2001).

- The system was in use from around 1962 to 1991, when the system was abandoned (H\&N, 1962; Haworth, 1991). No historical data was identified to indicate the lines were capped to prevent unauthorized discharge. Recent site visits confirm several drains from contributing buildings appear open and accessible (IT, 2001).

- Radionuclide contamination is not expected at this CAS based on historical information; however, the potential still exists based on process knowledge of the activities conducted in Area 3 (i.e., underground nuclear testing).

- Previous investigations of septic tanks at the NTS (REECo, 1995) found that COPCs were generally observed in septic tanks at higher concentrations than in leachfield soils.

- Within the leachfield, soil immediately beneath leachfield distribution lines usually show the highest concentration of COPCs (DOE/NV, 1998). This assumption holds for the abandoned leachfield; however, saturated conditions at the currently fenced leachfield may have allowed soluble constituents and any liquid phase to migrate to the surface. Additionally, a potential exists for the currently fenced leachfield to have a lagoon-type configuration instead of the typical leachfield configuration with distribution box and distribution lines. A lagoon configuration with an outfall pipe changes the distribution of COPCs to directly beneath the discharge end of the outfall pipe and the bottom of the lagoon where contaminants would concentrate due to settling and infiltration/evaporation.

- Saturated conditions within the currently fenced leachfield are known to have existed which contribute to a greater potential for lateral migration and/or overflow versus vertical migration beyond the spatial boundaries (Haworth, 1990; Watson, 1990). Migration may extend up to $15 \mathrm{ft}$ beyond distal ends of distribution lines (or the bermed edge) of the currently fenced leachfield. This assumption does not apply for the older, abandoned potential leachfield where primarily unsaturated conditions are assumed so that lateral migration would be limited to within $5 \mathrm{ft}$ of distal ends of lines based on previous leachfield investigations (DOE/NV, 1999a, 1999b, and 2000a).

- Process knowledge of previous leachfield investigations indicate that vertical migration is not expected to infiltrate past $10 \mathrm{ft}$ below the native soil interface. This assumption applies to both the fenced leachfield and older, potential leachfield.

- No previous sampling, geophysics, or radiological surveys have been identified. 
Below are listed some general CSM elements common to all six CASs:

- Groundwater impacts are not expected in Area 3 and Area 20

- Depth to groundwater in Area 3 generally ranges from approximately 1,500 ft bgs at the south end to 1,885 ft bgs at the north end (DRI, 1988). Within Area 3, the approximated depth to groundwater is $1,610 \mathrm{ft}$ bgs (Wuellner, 1994).

- Depth to groundwater in Area 20 generally ranges from 1,950 ft to 2,350 ft bgs (DRI, 1996 and 1988)

- Future Land Use: Area 20 is located within the Nuclear Test Zone, while Area 3 is located within the Nuclear and High Explosive Zone under Alternative 3 (DOE/NV, 1996a). Both zones include compatible defense and nondefense research, development, and testing projects and activities. These land-use scenarios limit future uses to industrial activities; therefore, future residential uses are not considered.

- Exposure Scenario: Site workers may be exposed to COCs through oral ingestion, inhalation, or dermal contact (absorption) of septage and soils due to inadvertent disturbance of contaminated structures and/or soils. 


\section{A.2.0 Phase I DQOs}

This section discusses the DQOs for the Phase I investigation of CAU 356.

\section{A.2.1 Step 1, State the Problem}

Hazardous and/or radioactive constituents may be present at CAU 356 at concentrations that could potentially pose a threat to human health and the environment.

\section{A.2.2 Step 2, Identify the Decision}

Determine whether COPCs are present at each CAS.

\section{A.2.2.1 Alternative Actions to the Decision}

If COPCs do not exceed PALs, further assessment of the CAS is not required. If PALs are exceeded, a Phase II investigation will be conducted at the CAS to further characterize the CAS.

\section{A.2.3 Step 3, Identify the Inputs to the Decision}

Historical records indicate the source, general location, and types of potential COCs that could be expected at CAU 356. However, previous sampling efforts do not accurately define the contaminant concentrations greater than PALs within each CAS. In order to resolve the decision, new sample data must be collected and analyzed following these two criteria: (1) sample in areas most likely to be contaminated, and (2) the analyses must be sufficient to detect any contamination present within those samples. Additional biasing factors to support the sample collection activities and meet the first criterion include configuration of the mud pits and septic system, field-screening methods, and field observations.

Table A.2-1 lists the information inputs, the source of information for each input, and the proposed methods to collect the new data. The last column addresses the appropriate QA/QC required for a particular data collection activity and is determined by the intended use of the resulting data in decision making.

Other information needs identified for Phase I not directly related to determining if contamination is present above PALs are also listed in Table A.2-1 and include: 
Table A.2-1

Identified Information/Data Needs to Resolve Decision

(Page 1 of 3)

\begin{tabular}{|c|c|c|c|}
\hline Information/Data Needs & $\begin{array}{l}\text { Source of Information/Data } \\
\text { (e.g., existing or new data) }\end{array}$ & Proposed Collection Methods & Measurement Quality ${ }^{\mathrm{a}}$ \\
\hline \multirow{6}{*}{$\begin{array}{l}\text { Information needs to meet } \\
\text { Criteria \#1: If contamination is } \\
\text { present, it will be sampled } \\
\text { Biasing Factors in Choosing } \\
\text { Sample Locations: } \\
\text { (1) Source and location of } \\
\text { release of COCs } \\
\text { (2) Configuration of mud pit and } \\
\text { landfill } \\
\text { (3) Configuration of septic } \\
\text { system components } \\
\text { (4) Field-screening results } \\
\text { (5) Field observations of surface } \\
\text { and soil conditions } \\
\text { (6) Utilities or other access } \\
\text { problems }\end{array}$} & $\begin{array}{l}\text { (1) Historical records and process knowledge (i.e., CSM) } \\
\text { provide sources of effluent stream and general location } \\
\text { of release of COCs for both mud pits and septic system. }\end{array}$ & $\begin{array}{l}\text { Documented in CSM, no additional data collection } \\
\text { needed. }\end{array}$ & Qualitative \\
\hline & $\begin{array}{l}\text { (2) Lateral boundaries of mud pits known from previous } \\
\text { site visits (Bull, 2001). } \\
\text { Data Need: Collect geophysical data for configuration } \\
\text { of mud pits. }\end{array}$ & $\begin{array}{l}\text { Perform geophysical surveys consisting of electrical } \\
\text { imaging methods prior to sample collection. }\end{array}$ & Semiquantitative \\
\hline & $\begin{array}{l}\text { (3) General configuration of septic system available, but } \\
\text { inconsistencies have been identified. } \\
\text { Data Need: Locate and verify system components. }\end{array}$ & $\begin{array}{l}\text { Locate/verify configuration by excavation with backhoe; } \\
\text { may conduct visual, and/or video, and/or } \\
\text { electromagnetic surveys of distribution pipes to establish } \\
\text { integrity, content, and verify configuration. }\end{array}$ & Qualitative \\
\hline & $\begin{array}{l}\text { (4) Data Need: Possibly field screen soil for TPH at } \\
\text { mud pits only if data from other biasing factors are } \\
\text { insufficient to make decision on sample location. } \\
\text { Data Need: Collect radiological survey data on surface } \\
\text { of mud pits and leachfields. }\end{array}$ & $\begin{array}{l}\text { A gridded area near proposed sample collection points } \\
\text { (based on CSM) within the mud pit may be field } \\
\text { screened for TPH (primary COPC) to help guide the } \\
\text { selection of most appropriate sample to submit to } \\
\text { laboratory (i.e., submit sample with highest } \\
\text { field-screening result). } \\
\text { Perform radiological survey using appropriate } \\
\text { technology for the site to initially screen for presence of } \\
\text { radionuclides. }\end{array}$ & Semiquantitative \\
\hline & $\begin{array}{l}\text { (5) Current field observations are limited due to } \\
\text { tumbleweeds and access restrictions. } \\
\text { Data Need: Collect field observations on surface and } \\
\text { subsurface conditions for staining, odor, presence of } \\
\text { debris, etc. }\end{array}$ & $\begin{array}{l}\text { Conduct field observations after prefield activities are } \\
\text { complete (e.g., removal of tumbleweeds) and during } \\
\text { sample collection. The observations will be documented } \\
\text { in the field and may be used in selecting biased sample } \\
\text { locations. }\end{array}$ & Qualitative \\
\hline & $\begin{array}{l}\text { (6) Access problems exist at many mud pits and the } \\
\text { mud disposal landfill. Underground utilities are expected } \\
\text { in the Area } 3 \text { Camp near the septic system. } \\
\text { Data Need: Document all utilities and access } \\
\text { restrictions in relation to potential sampling areas. }\end{array}$ & $\begin{array}{l}\text { Complete a checklist to document locations of } \\
\text { underground and aboveground utilities prior to intrusive } \\
\text { work. Determine if an alternate sampling technique can } \\
\text { access sampling location; if not, then determine } \\
\text { alternate sampling area. } \\
\text { U20b Crater: Personnel can access the crater bottom } \\
\text { by walking down a designated path to be marked prior to } \\
\text { sampling activities. Equipment will be manually carried } \\
\text { or placed on wheeled-skid and hoisted down via ropes. }\end{array}$ & Qualitative \\
\hline
\end{tabular}


Table A.2-1

Identified Information/Data Needs to Resolve Decision

(Page 2 of 3 )

\begin{tabular}{|c|c|c|c|}
\hline Information/Data Needs & $\begin{array}{l}\text { Source of Information/Data } \\
\text { (e.g., existing or new data) }\end{array}$ & Proposed Collection Methods & Measurement Quality ${ }^{\mathrm{a}}$ \\
\hline $\begin{array}{l}\text { Continued Criteria \#1: If } \\
\text { contamination is present, it will } \\
\text { be sampled. }\end{array}$ & $\begin{array}{l}\text { The culmination of all the biasing data collected } \\
\text { above will aid in determining the areas most likely to } \\
\text { be contaminated anywhere within a CAS. } \\
\text { Data need: Collect samples from affected media in } \\
\text { areas most likely contaminated and submit for laboratory } \\
\text { analysis. }\end{array}$ & $\begin{array}{l}\text { Mud Pits: Appropriate sampling techniques will be } \\
\text { utilized to collect mud/soil cutting samples at biased } \\
\text { locations within mud pits, and submit to laboratory for } \\
\text { analyses. } \\
\text { Septic System: Appropriate techniques will be utilized to } \\
\text { collect liquid/sludge/sediment within septic tank and } \\
\text { distribution box (manhole); collect limited number of soil } \\
\text { samples within the leachfield(s), and submit to } \\
\text { laboratory for analysis. }\end{array}$ & Quantitative \\
\hline $\begin{array}{l}\text { Information Needs to Meet } \\
\text { Criteria \#2: If contamination is } \\
\text { present, it will be detected. } \\
\text { Types of analyses }\end{array}$ & $\begin{array}{l}\text { Historical records of drilling practices provide general list } \\
\text { of potential contaminants to be expected at mud pits. } \\
\text { Historical records and interviews provide a general list of } \\
\text { potential contaminants from source buildings connected } \\
\text { to septic system. } \\
\text { Existing sample data from the preliminary assessment } \\
\text { conducted in } 1997 \text { on CAS 03-09-01, 03-09-03, } \\
\text { 03-09-04, and 03-09-05 (Bordelois, 1998a,b, and c; } \\
\text { Forsgren, 1998); VOCs, SVOCs, RCRA metal, TPH, } \\
\text { and radionuclides were detected but levels were not } \\
\text { above PALs, except for arsenic, which was within NTS } \\
\text { background concentrations. } \\
\text { Data Need: Submit newly collected sample data to } \\
\text { laboratory and analyze for full suite of COPCs to include } \\
\text { VOCs, SVOCs, RCRA metals, PCBs, TPH, and } \\
\text { radionuclides. }\end{array}$ & $\begin{array}{l}\text { Existing data documented in site background and/CSM. } \\
\text { All new samples collected will be analyzed using the } \\
\text { appropriate analytical method provided in Section } 6.0 \text { of } \\
\text { the SAFER Plan. }\end{array}$ & Quantitative \\
\hline $\begin{array}{l}\text { Meet NAC requirements for final } \\
\text { closure of septic tank. }\end{array}$ & $\begin{array}{l}\text { NAC regulations on closure requirements are known. } \\
\text { Data Need: Collect liquid/sludge samples within septic } \\
\text { tank. } \\
\text { Data Need: Collect and analyze integrity samples } \\
\text { adjacent and/or beneath septic tank and distribution } \\
\text { box/manhole. } \\
\text { Data Need: Volume of septage in tank for waste } \\
\text { removal, tank dimensions, and construction. } \\
\text { Data Need: Verification samples for any area requiring } \\
\text { soil and/or structure removal. }\end{array}$ & $\begin{array}{l}\text { Samples will be collected following standard } \\
\text { procedures, and submitted for laboratory analysis for } \\
\text { full-suite analysis. } \\
\text { Tank dimensions, construction, and septage volume will } \\
\text { be verified through excavation and observation, and will } \\
\text { be documented in field reports. } \\
\text { Septic sludge, if present and sampled, will be submitted } \\
\text { to laboratory for TCLP VOCs, TCLP SVOCs, and TCLP } \\
\text { metals analysis, radionuclides, and coliform. }\end{array}$ & Quantitative \\
\hline
\end{tabular}


Table A.2-1

Identified Information/Data Needs to Resolve Decision

(Page 3 of 3)

\begin{tabular}{|l|l|l|l|}
\hline Information/Data Needs & \multicolumn{1}{|c|}{$\begin{array}{c}\text { Source of Information/Data } \\
\text { (e.g., existing or new data) }\end{array}$} & Proposed Collection Methods \\
\hline \hline $\begin{array}{l}\text { Waste Management } \\
\text { Requirements }\end{array}$ & $\begin{array}{l}\text { IDW determined through environmental sample results. } \\
\text { Waste will not be considered "listed" unless contrary } \\
\text { information is discovered during the investigation. }\end{array}$ & N/A \\
\hline Housekeeping Activities & $\begin{array}{l}\text { The types and amount of debris for removal is generally } \\
\text { known through visual observations. } \\
\text { Data need: Collect samples anywhere potentially } \\
\text { hazardous substances may have leaked or if contents } \\
\text { are unknown (e.g., unlabeled drum). } \\
\text { Data need: Collect verification samples for any soil } \\
\text { removal activities associated with housekeeping. }\end{array}$ & $\begin{array}{l}\text { Submit samples to laboratory for full-suite analysis } \\
\text { unless specific COCs can be determined. }\end{array}$ & $\begin{array}{l}\text { Qualitative for } \\
\text { photodocumentation and } \\
\text { Quantitative for analyses }\end{array}$ \\
\hline GPS Coordinates & $\begin{array}{l}\text { Data Need: Collect Global Positioning System (GPS) } \\
\text { measurements for all sample and screening locations as } \\
\text { well as physical boundaries. }\end{array}$ & $\begin{array}{l}\text { GPS measurements will be collected as points, lines, } \\
\text { and areas in accordance with standard procedures. } \\
\text { caps measurements will be acquired in a manner } \\
\text { caple of achieving horizontal accuracy of less than }\end{array}$ & Quantitative \\
\hline
\end{tabular}

${ }^{a}$ This column addresses the measurement quality assigned to all data collection activities, and is determined by the intended use of the resulting data in decision making. The levels are assigned as quantitative, semiquantitative, and qualitative.

Quantitative: Data measures the quantity or amount of a characteristic or component within the population of interest. These data require the highest level of QA/QC in collection and measurement systems because the intended use of the data is to resolve primary decisions (i.e., rejecting or accepting the null hypothesis) and/or verifying closure standards have been met. Laboratory analytical data are usually assigned as quantitative data.

Semiquantitative: Data indirectly measures the quantity or amount of a characteristic or component of interest. Inferences are drawn about the quantity or amount of a characteristic or component because a correlation has been shown to exist between the indirect measurement and the results from a quantitative measurement. The QA/QC requirements on semiquantitative collection and measurement systems are high but may not be as rigorous as a quantitative measurement system. Semiquantitative data contribute to decision making, but are not used alone to resolve primary decisions. The data are often used to guide investigations toward quantitative data collection.

Qualitative: Data identify or describe the characteristics or components of the population of interest. The QA/QC requirements are the least rigorous on data collection methods and measurement systems. Professional judgement is often used to generate qualitative data. The intended use of the data is for information purposes, to refine conceptual models, and guide investigations rather than resolve primary decisions. This measurement of quality is typically assigned to historical information and data where $\mathrm{QA} / \mathrm{QC}$ may be highly variable or not known. 
- Collect GPS coordinates of all sample locations and delineation of boundaries of each CAS feature (mud pit or leachfield).

- Perform housekeeping activities on miscellaneous debris at sites.

- Collect data to meet closure requirements for the septic tank under NAC regulations.

- Collect waste management information.

\section{A.2.3.1 Determine the Basis for Preliminary Action Levels}

Laboratory analytical results will be compared to the following PALs to evaluate if COPCs are present at levels that may pose an unacceptable risk to human health and/or the environment and require a Phase II investigation:

- $\quad$ EPA Region 9 risk-based PRGs for industrial soils (EPA, 2000b)

- $\quad$ TPH concentrations above the TPH limit of 100 ppm per the NAC 445A.2272 (NAC, 2000d)

- Background concentrations for RCRA metals will be evaluated when natural background exceeds the PAL (i.e., arsenic). A sediment sampling effort performed by the Nevada Bureau of Mines and Geology (NBMG, 1998) provides relevant analytical data for numerous metals, including the eight RCRA metals. Statistical analysis of this data indicate background concentrations (mean plus two standard deviations) applicable to soil samples collected from the NTS for investigation of CASs (Moore, 1999).

- For COPCs without established PRGs, a similar protocol as EPA Region 9 will be used in establishing an action level.

- The PALs for radionuclides are isotope-specific and defined as the maximum concentration for that isotope found in environmental samples taken from undisturbed background location in the vicinity of the NTS, as presented in McArthur and Miller (1989), Atlan-Tech (1992), and Black and Townsend (1996).

\section{A.2.3.2 Potential Sampling Techniques and Appropriate Analytical Methods}

For the initial phase of data collection in the mud pits, biased samples will be collected within the $\mathrm{mud} /$ soil cuttings from locations determined by the criteria discussed in Table A.2-1 and analyzed. For the septic system, biased samples will be collected from soil, liquid, and sludge for analysis from the septic tank, distribution box, and leachfield. Sample collection and handling activities will follow standard procedures. 
Section 6.0 of the SAFER plan provides the analytical methods and laboratory requirements (i.e., detection limits, precision, and accuracy requirements). Specific analyses required for the disposal of IDW are identified in Section 5.0 of the SAFER plan. Unless otherwise required by the results of this DQO and stated in the SAFER plan, this investigation will adhere to the Industrial Sites QAPP (DOE/NV, 1996b).

\section{A.2.4 Step 4, Define the Boundaries of the Study}

The purpose of this step is to define the target population of interest and specify the spatial and temporal features of that population that are pertinent for decision making.

\section{A.2.4.1 Define the Target Population}

Two target populations have been identified for the mud pits and mud disposal landfill. One population is the COC concentrations within mud/soil cuttings from the surface to the textural discontinuity, while the second population consists of COC concentrations in the native soil below and adjacent to the textural discontinuity.

The target population for the septic system consists of COC concentrations for both the liquid and sludge phases of the septic tank; sludge/sediment within distribution box/manhole; surface soil above the leachrock, and soil below and adjacent to the leachrock/native soil interface within the leachfield; and soil adjacent to/beneath the septic tank and distribution box (e.g., outlet pipe, tank bottom).

\section{A.2.4.2 Determine the Spatial and Temporal Boundaries}

Each mud pit is considered geographically independent. The lateral boundaries are defined by the surrounding berm for each pit, or the fenced edge of a crater regardless if bermed or not. The mud disposal landfill geographic boundary is the crater diameter. Each mud pit can be divided into two strata: (1) surface of mud down to the textural discontinuity (i.e., mud/native soil interface), and (2) soil below the textural discontinuity down to $10 \mathrm{ft}$. The same strata apply to the mud disposal landfill; however, the second strata will be determined by depth to bedrock, which is assumed less than $5 \mathrm{ft}$.

Geographic boundaries for the septic system are defined by the structures that comprise the system components such as the collection line piping, septic tank, manhole/distribution box, and the dimensions of leachfield (unknown). The soils within the leachfield can be divided into two strata: 
(1) surface soils down to the top of the leachrock, and (2) soil below the leachrock/native soil interface to a depth of $10 \mathrm{ft}$.

Temporal boundaries are those time constraints set up by weather conditions and project schedules set in baseline. Weather conditions in Area 20 are an important temporal constraint and require that investigation activities not be scheduled during winter months. There are no time constraints on collecting samples as environmental conditions at all sites will not significantly change in the near future, and conditions would have stabilized over the last 10 to 25 years since the systems were last used. Current schedules for submitting the SAFER Plan are June 12, 2001, for the Draft SAFER Plan and August 28, 2001, for the Final SAFER Plan. Field work is currently scheduled to begin in Fiscal Year 2002.

\section{A.2.4.3 Identify Practical Constraints}

The NTS-controlled activities may affect the ability to characterize this site. Underground utilities are expected to exist at the Area 3 Camp. Adverse weather conditions and health and safety concerns may affect this site, especially for Area 20. Certain health and safety hazards may exist in attempting to access the pits and septic tank. Area 20 is remote, which may create logistical constraints.

\section{A.2.4.4 Define the Scale of Decision Making}

The scales of decision making are defined here so that individual CASs may be advanced to a Phase II characterization, if necessary, rather than submitting the entire CAU to a Phase II characterization. The decision scale also allows for corrective actions appropriate to each CAS rather than the entire CAU.

Scale for mud pits: Decision making will be based on each CAS as one unit, such that both pits (if more than one) are closed in a similar manner, even though only one pit may contain contamination above PALs. This is based on recirculation processes used during drilling activities.

Scale for septic system: Decision making will be based on each individual component such as septic tank versus leachfield soils. This allows greater flexibility in corrective action alternatives for each component. 


\section{A.2.5 Step 5, Develop a Decision Rule}

This step integrates outputs from previous steps with the inputs developed in this step into a decision rule ("If...then...") statement. This rule describes the conditions under which possible alternative actions would be chosen.

\section{A.2.5.1 Specify the Population Parameter}

Because the sampling in Phase I is biased towards worst-case concentrations, the population parameter will be the maximum observed concentration of each COC within the target population(s).

\section{A.2.5.2 Choose an Action Level}

Action levels were defined in Step 3 (Section A.2.3.1).

\section{A.2.5.3 Measurement and Analysis Methods}

This step was previously addressed in Step 3 (Section A.2.3.2). The measurement and analysis methods given in Section 6.0 of the SAFER Plan are capable of performing over the expected range of values, and that the detection limit of the measurement method to be used is less than the action limit for each COPC.

\section{A.2.5.4 Decision Rule}

If the maximum observed concentration of any $\mathrm{COC}$ of a target population within the decision unit, as defined in Step 4, exceeds the PALs set in Step 3, then conduct a Phase II investigation. If the observed maximum is not greater than PALs, then the decision will be no further action, and a closure report will be prepared.

\section{A.2.6 Step 6, Specify Tolerable Limits on Decision Errors}

The sampling approach for the Phase I investigation relies upon biased samples; therefore, statistical analysis is not appropriate.

The baseline condition (i.e., null hypothesis) and alternative condition for the Phase I investigation are:

- Baseline condition - COCs are present above PALs

- Alternative condition - COCs are not present above PALs 


\section{A.2.6.1 False Rejection Decision Error}

The false rejection (alpha error) would mean deciding that COCs are not present when they really are, increasing risk to human health and environment.

A false rejection decision error (where consequences are more severe) is controlled by meeting the following two criteria: (1) a high confidence that location selected will identify contamination of concern if it were present anywhere within the CAS, and (2) that analyses conducted will be sufficient to detect any contamination of concern present in the samples.

To satisfy that the first criterion is met, the Phase I data collection will sample in areas that are most likely to be contaminated (worst-case) by considering the following characteristics: Source and location of release, chemical nature and fate properties, physical transport pathways and properties, and hydrologic drivers. These characteristics were considered during the development of the conceptual model (see Section A.1.3). Other biasing factors, as listed in Step 3 in Table A.2-1, will be utilized during the investigation to further ensure that the first criteria is met. To meet the second criterion, all Phase I samples will be analyzed for a full suite of COPCs. Following established procedures and QA/QC protects against false negatives.

If the criteria described above are not met, then the investigation will do directly to Phase II.

\section{A.2.6.2 False Acceptance Decision Error}

The false acceptance (beta error) would mean accepting that COCs are present when they are not, resulting in increased costs for unneeded characterization.

The false acceptance decision error is controlled by protecting against false-positive analytical results. False-positive results are typically attributed to laboratory errors and sampling/handling errors. Quality assurance/quality control samples such as field blanks, trip blanks, laboratory control samples, and method blanks should minimize the risk of a false-positive analytical result. Other factors are using clean sampling equipment and containers, following established procedures, and the history of similar sites with low beta errors. 


\section{A.2.6.3 Quality Assurance/Quality Control}

Quality control samples will be collected as required by established procedures. The required QC samples include:

- Trip blanks (1 per sample cooler containing VOC environmental samples)

- Equipment blanks (1 per sampling event for each type of decontamination procedure)

- Source blanks (1 per lot for such things as polyurethane bags or direct-push liners)

- $\quad$ Field duplicates ( 1 per 20 environmental samples or 1 per CAS if less than 20 collected)

- Field blanks (1 per 20 environmental samples)

- Matrix spike/matrix spike duplicate (1 per 20 environmental samples or 1 per CAS per matrix if less than 20 collected)

Additional QC samples may be submitted based on site conditions.

Quality data indicators of precision, accuracy, comparability, completeness, and representativeness are defined in the Industrial Sites QAPP. Site-specific data quality indicators are discussed in more detail in Section 6.0 of the SAFER Plan.

\section{A.2.7 Step 7, Optimize the Design for Obtaining Data}

Biased sampling will be conducted at CAU 356 during Phase I. The Phase I sampling strategy targets worst-case contamination by sampling the septic tank components, mud pits, and mud disposal landfill at locations with the highest potential for contamination. Process knowledge indicates that contamination, if any, is confined to the spatial boundaries of the sites.

\section{A.2.7.1 Phase I}

The objective of the Phase I investigation strategy is to determine whether COC concentrations are present above PALs. Laboratory analytical results from this phase will be used to confirm the presence or absence of COPCs and if the concentrations exceed PALs. If COCs are located within a CAS, that CAS will be further assessed in a Phase II investigation. The COPCs determined not to be present in Phase I will be eliminated for further consideration during a Phase II characterization effort. It is important to note that the target population(s) to be investigated in Phase I are or may be 
different than those in Phase II; the target populations for this phase are documented in the relevant sections below.

The biased locations will be selected by the Site Supervisor as field data are generated (i.e., geophysics, field-screening results). Additional samples may be collected for waste management characterization and disposal purposes.

Field-screening may be instituted in the field to assist in providing an additional semiquantitative screening measurement of COPC concentrations when other biasing data are insufficient to locate the area most likely to be contaminated. These field-screening results will help guide the selection of the most appropriate sampling location for collection of laboratory samples. Potential field-screening methods with the respective field-screening level are presented below:

- VOC headspace screening levels are established at 20 ppm or 2.5 times background, whichever is greater, using a photoionization detector.

- The radiation (alpha/beta) screening level is defined as the mean surficial-background activity level plus two times the standard deviation of that mean.

- TPH screening levels are established at 100 ppm, using Hanby or other appropriate field test kit. Soil will be field screened for TPH only at the mud pit/mud landfill sites.

Site preparation activities for each CAS are documented below in the relevant section.

\section{A.2.7.2 CAS 03-04-01, Area 3 Change House Septic System}

The sampling strategy for the Area 3 Change House Septic System will be similar to activities outlined in the Work Plan for Leachfield Corrective Action Units (DOE/NV, 1998). Phase I activities at this CAS will consist of confirming the configuration of system components and sample collection of the following target populations: the COC concentrations of liquid and sludge phases of the septic tank; sludge/sediment within the distribution box/manhole; surface soil above the leachrock and soil below and adjacent to the leachrock/native soil interface within the leachfield; and soil adjacent to/beneath the septic tank and distribution box (e.g., outlet pipe, tank bottom).

Site preparation activities will consist of removing tumbleweeds from the leachfield area, inspecting the surface features of the fenced leachfield, conducting a radiological walkover survey, and locating and verifying the configuration of the septic system components through intrusive investigation. If 
additional distribution structures and/or leachfields are identified, they will be inspected for configuration and sampled in a similar manner as outlined below. Visual inspection, video surveys, and/or geophysical surveys may also be conducted to investigate the distribution lines associated with this CAS. Excavation using a backhoe will be the primary intrusive investigation technique to expose all subsurface structures during Phase I activities.

Sampling will be conducted of the septic tank contents and the manhole/distribution box contents. Samples of both the liquid and sludge phases from both chambers within the septic tank will be collected and analyzed, if recoverable. A sediment/soil sample will be collected within the manhole in an appropriate area as determined by field observations. Additional biased locations to be sampled include underlying soil at both the inlet and outlet ends of the septic tank and the identified outlet end(s) of the manhole/distribution box. To facilitate the closure of the septic tank under NAC requirements (NAC, 2000a), integrity samples will be collected during Phase I in soils adjacent to and/or beneath the septic tank and manhole/distribution box to confirm releases have not occurred from these structures. The tank dimensions, construction, and volume of septage will be documented for closure purposes.

A minimum of three biased locations within each identified leachfield will be sampled for one to two discrete samples per location. These biased locations will target areas most likely to have been contaminated by effluent disposal and provide a "worst-case" scenario. These sample results will aid in confirming whether or not the leachfield component of the septic system requires a Phase II investigation. The exact locations within each leachfield will be selected by the Site Supervisor based upon site characteristics determined through field observations. For the currently fenced leachfield, samples may potentially consist of soil collected within the top $12 \mathrm{in}$. of leachfield cover and the first 12 in. of soil immediately beneath the leachrock base. Only the surface sample will be collected if field observations indicate that distribution lines and leachrock are not present at this leachfield. If the presence of the second, abandoned leachfield is confirmed, only one sample per location will be collected and analyzed from the first 12 in. of soil beneath the leachrock base. Figure A.2-1 shows the potential sample locations based on current site conditions.

All necessary closure activities associated with the septic tank will be considered Phase I activities. This will consist of pumping out the tank contents for disposal and either removing the tank structure 


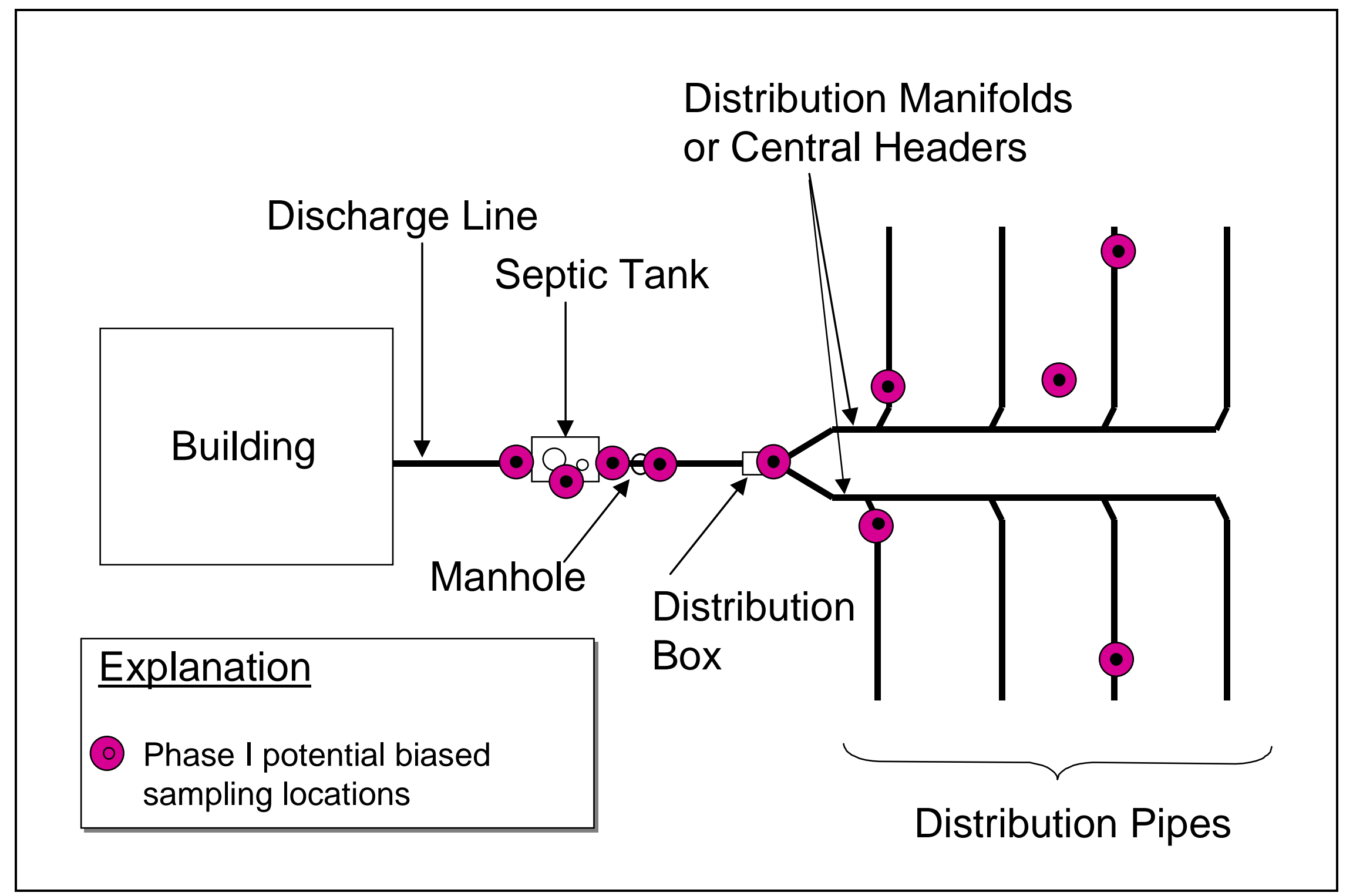


or leaving in place and backfilling according to NAC regulations (NAC, 2000a). Grouting of any open access points will be considered Phase I activities.

\section{A.2.7.3 CASs 03-09-01, 03-09-03, 03-09-04, and 03-09-05, Mud Pits and Mud Pit Spill Over}

These four CASs are located in Area 3 and consist of either one or two mud pits and one mud spill. Phase I activities at these CASs will consist of determining the configuration of each mud pit and sample collection for laboratory analysis for the target population of COC concentrations within mud/soil cuttings from the surface to the textural discontinuity. The sampling strategy consists of biased sampling.

Several site preparation activities and preliminary investigation techniques must be completed prior to sampling activities for the Area 3 mud pit CASs. These activities include the following:

- Removing tumbleweeds from within each pit

- Inspecting the surface features of each pit for staining, debris, etc.

- Constructing access ramps into pits, where required, for backhoe and personnel entrance

- Conducting radiological surveys within each pit

- Conducting geophysical surveys within each pit

Geophysical surveys will be performed within the spatial boundaries of each mud pit to facilitate the selection of biased sample locations, determine the configuration of each pit (e.g., construction of base), and identify if debris is present within the pits. The surveys may be extended several feet past the boundaries to gather data on contrasting soil characteristics. The geophysical surveys will consist of electrical imaging methods to measure the subsurface resistivity and identify the transition between the clay characteristics of mud and the sands/gravels of native soil.

Although radionuclides are not expected COCs, a radiological survey will be performed over the entire surface of each mud pit, if feasible, to identify any potential areas of elevated radiological readings. Field screening for TPH may be conducted at initial areas targeted for biased sampling to further enhance the selection of sample areas most likely to be contaminated. A sample target area (based on geophysics and field observations) $40 \mathrm{ft}$ by $40 \mathrm{ft}$ will be divided into $10-\mathrm{ft}$ grids, where surface samples will be collected from the center of each grid for a total of 16 TPH screening samples. The grid locations with the highest TPH field-screening results will then be considered, 
along with other biasing data collected, in selecting the sample point for surface and subsurface sample collection and laboratory submittal.

Each mud pit will be sampled at a minimum of two biased locations within the defined spatial boundaries. Each sample location will consist of two discrete samples unless the configuration and depth of mud at a given location precludes two separate depths, in which case only one sample will be collected at that particular location. One sample will be collected at the surface ( 0 to 6 in.) within the mud/soil cuttings matrix, while the second sample will consist of an approximately 6-in. interval comprised of mud and native soil at the textural discontinuity. Collecting both mud and native soil at this discontinuity, ensures that contamination, if present, will be captured whether it is bound in mud matrix or leached into the native soil. Additional material adjacent to the initial sample location may be collected to ensure sufficient volume is submitted to satisfy analytical requirements. Figure A.2-2 shows both a planar view and cross-sectional view of potential sample locations based on the conceptual model for the mud pits. Exact sample locations will be determined in the field by the Site Supervisor. Locations will be selected in areas most likely to be contaminated based on the conceptual model and other biasing factors outlined in Step 3 (e.g., field-screening, geophysics).

The mud spill of CAS 03-09-01 will not be sampled during the Phase I activities. The mud characteristics at this location can be considered consistent with the results of the return mud pit and suction mud pit associated with this CAS. Therefore, the analytical results from these two muds pits will be utilized to determine if any further characterization strategies are necessary at this location during the Phase II efforts.

Only one housekeeping activity has been identified for the mud pits of Area 3 and involves the gravel/asphalt debris pile located within the spatial boundaries of the mud pit of CAS 03-09-05. The remaining debris pile will be removed through housekeeping operations. Any additional housekeeping activities identified during the course of the investigation will be documented and implemented.

\section{A.2.7.4 CAS 20-16-01}

Phase I activities at this CAS will consist of determining the configuration of the mud pit at the base of the crater and sample collection of the following target population: the COC concentrations within mud/soil cuttings from the surface to the textural discontinuity. The sampling strategy for 


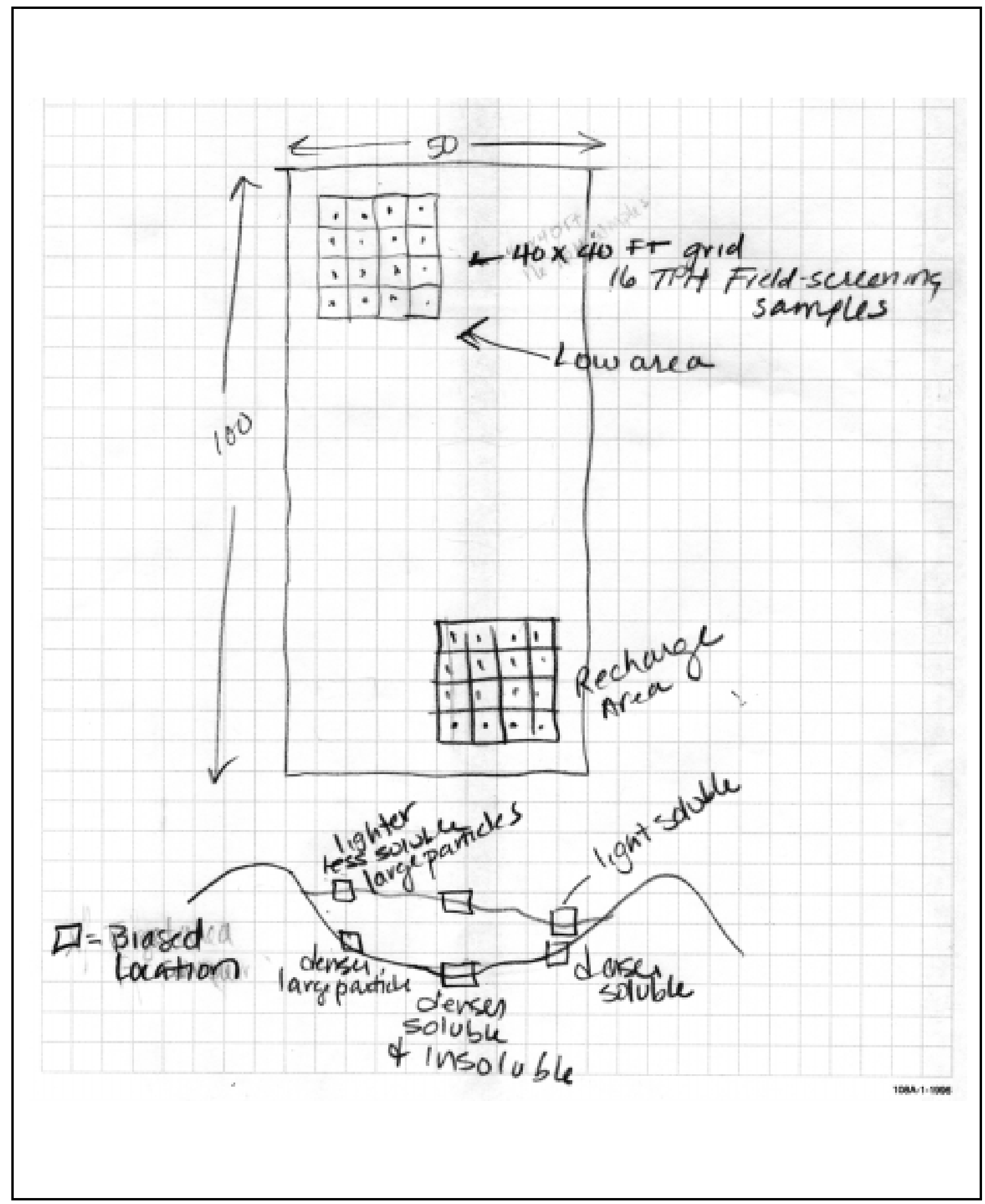

Figure A.2-2

Mud Pit Phase I Potential Sample Locations 
CAS 20-16-01 consists of biased locations within the mud pit located at the base of the crater and a shallow mud area located at the top of the crater near the access/discharge area.

Site preparation activities are minimal at this CAS and should consist primarily of health and safety precautions for accessing the crater. Access into the crater is restricted by steep slopes and rocky surfaces; therefore, all sampling will be conducted by manual means.

Several areas within and around the crater require housekeeping removal activities. Miscellaneous debris including concrete slabs, a small wooden building, wood pieces, metal objects, and cabling will be removed as housekeeping items. The site also contains drums of which at least two are addressed under another CAU. The CAS 20-22-21 containing these two drums has been moved into CAU 356 to expedite remediation. Sampling activities may be conducted in areas of debris removal at the discretion of the Site Supervisor based on field observations (e.g., soil staining). Contents of drums, if present and unknown, may be sampled for waste determination purposes.

The mud disposal landfill will be sampled at a minimum of two locations to be determined by the Site Supervisor based upon geophysical results and field observations. Each sample location will consist of two discrete samples unless the configuration and depth of mud at a given location precludes two separate depths, in which case only one sample will be collected at that particular location. One sample will be collected at the surface ( 0 to 6 in.) within the mud matrix, while the second sample will consist of an approximately 6-in. interval comprised of both mud and native soil at the textural discontinuity. Collecting both mud and native soil at this discontinuity ensures that contamination, if present, will be captured whether it is bound in mud matrix or leached into the native soil. Additional material adjacent to the initial sample location may be collected to ensure sufficient volume is submitted to satisfy analytical requirements.

The shallow mud area near the top of the crater will be sampled at one location to be determined by the Site Supervisor based upon site characteristics. The sample location will consist of one sample collected at the surface ( 0 to 6 in.) within the mud matrix. Additional material adjacent to the initial sample location may be collected to ensure sufficient volume is submitted to satisfy analytical requirements. 


\section{A.3.0 Phase II DQOs}

This section discusses the DQOs for the Phase II investigation for any CAS that requires further assessment based on Phase I results. The DQOs and conceptual model may be modified if Phase I results indicate the need.

\section{A.3.1 Step 1, State the Problem}

A corrective action is needed to complete site closure because COCs are present.

\section{A.3.2 Step 2, Identify the Decision}

Determine the extent of contamination for COCs identified above PALs in Phase I.

Determine if the corrective action is close-in-place or clean closure.

Determine if COCs remain in the soil following remediation, if clean closure is the preferred corrective action.

\section{A.3.2.1 Alternative Actions to the Decision}

If the extent has been determined, no further characterization efforts are required, and the type of closure alternative can be evaluated. If not, continue to collect required information.

If close-in-place is the preferred closure alternative, determine the appropriate use restriction. If clean closure is the preferred closure alternative, remediate and collect verification samples.

Following removal activities, if COCs in remaining soil are less than PALs, then remediation is complete and prepare a closure report; otherwise, continue remedial activities until COCs in the remaining soil are less than PALs.

\section{A.3.3 Step 3, Identify the Inputs to the Decision}

To resolve the decision statement(s), the necessary information for implementing a corrective action must be identified and collected.

- The following information needs are identified for both close-in-place or clean closure as preferred alternatives: 
- Soil samples within native soil, both vertically and laterally, to determine when the extent of contamination decreases below PALs

- Resource availability (cost analysis of preferred closure alternatives)

- The following information needs are identified if clean closure as preferred alternative:

- Volume of material to be removed

- Potential remediation waste characteristics

- Post-removal concentrations of COCs

- The following information inputs are needed for the support of collecting soil samples during Phase II:

- Revised COC list for laboratory analysis of Phase II samples

- Field-screening method appropriate to the COCs present

- Sampling method appropriate to bound contamination, if different than initially proposed sample design

Table A.3-1 lists the information inputs, the source of information for each input, and the proposed methods to collect the new data.

\section{A.3.3.1 Choose the Basis for Preliminary Action Levels}

The PALs for Phase II are the same used during Phase I. Refer to Section A.2.3.1 for a list of various PALs.

\section{A.3.3.2 Potential Sampling Techniques and Appropriate Analytical Methods}

Appropriate sample collection techniques will be utilized for Phase II activities to determine the extent of contamination. Appropriate collection techniques will be implemented to adequately define the vertical extent of contamination.

Section A.2.3.2 discusses the analytical methods to be used in Phase II (same as Phase I). 
Table A.3-1

Identified Information/Data Needs to Resolve Decision

(Page 1 of 2)

\begin{tabular}{|c|c|c|c|}
\hline $\begin{array}{l}\text { Information/Data } \\
\text { Needs }\end{array}$ & $\begin{array}{l}\text { Source of Information/Data } \\
\text { (e.g., existing or new data) }\end{array}$ & $\begin{array}{l}\text { Sample or Data Collection } \\
\text { Method (if appropriate) }\end{array}$ & Measurement Quality \\
\hline \multirow{3}{*}{ Extent of contamination } & $\begin{array}{l}\text { Data Need: Determine if field-screening methods } \\
\text { are available or required for COCs identified in } \\
\text { Phase I. } \\
\text { Field-screening levels are known for VOCs, TPH, } \\
\text { and radionuclides. }\end{array}$ & $\begin{array}{l}\text { Method for field screening, if appropriate, to } \\
\text { be determined in Phase II and will be } \\
\text { documented. }\end{array}$ & Semiquantitative \\
\hline & $\begin{array}{l}\text { Existing analytical information: Phase } 1 \text { data will } \\
\text { provide maximum observed concentrations above } \\
\text { PALs within sampled target populations. } \\
\text { Data Need: Collect soil samples for laboratory } \\
\text { analysis at additional sample locations both } \\
\text { vertically and laterally to bound contamination } \\
\text { above PALs. }\end{array}$ & $\begin{array}{l}\text { Collect samples at locations tentatively } \\
\text { identified in sample design and submit to } \\
\text { laboratory for analysis. }\end{array}$ & Quantitative \\
\hline & $\begin{array}{l}\text { Dimensions and configuration of septic system } \\
\text { components and mud pits will be known after } \\
\text { Phase I activities to plan sample locations. }\end{array}$ & $N / A$ & Qualitative \\
\hline \multirow{4}{*}{$\begin{array}{l}\text { Other data requirements for } \\
\text { close-in place and/or clean } \\
\text { closure alternative }\end{array}$} & $\begin{array}{l}\text { Physical boundaries of mud pits known from site } \\
\text { visits (Bull, 2001). } \\
\text { Phase I geophysical data available on } \\
\text { approximate depth of mud and configuration of pit. }\end{array}$ & $N / A$ & Semiquantitative \\
\hline & $\begin{array}{l}\text { Dimensions and configuration of leachfield(s) and } \\
\text { other septic system components will be known } \\
\text { after Phase I activities. }\end{array}$ & $N / A$ & Qualitative \\
\hline & $\begin{array}{l}\text { Meteorologic Data: Existing information provided } \\
\text { in the NTS and Yucca Mountain Site } \\
\text { Characterization Project data on annual } \\
\text { precipitation, evapotranspiration, and weather } \\
\text { (Meyers and Nordenson, 1962). }\end{array}$ & $N / A$ & Qualitative \\
\hline & $\begin{array}{l}\text { Geologic/Hydrologic Data: } \\
\text { Reports on hydrologic data for NTS available and } \\
\text { includes depth to groundwater. } \\
\text { Data Need: Specific geologic/hydrologic } \\
\text { characteristics of the site. }\end{array}$ & $\begin{array}{l}\text { General soil and alluvial characteristics will } \\
\text { be noted on sample collection log. } \\
\text { Geotechnical samples may be collected } \\
\text { within native soil beneath mud pits/ } \\
\text { leachfield, if required for corrective action. }\end{array}$ & Qualitative \\
\hline
\end{tabular}


Table A.3-1

Identified Information/Data Needs to Resolve Decision

(Page 2 of 2)

\begin{tabular}{|c|c|c|c|}
\hline $\begin{array}{c}\text { Information/Data } \\
\text { Needs }\end{array}$ & $\begin{array}{l}\text { Source of Information/Data } \\
\text { (e.g., existing or new data) }\end{array}$ & $\begin{array}{c}\text { Sample or Data Collection } \\
\text { Method (if appropriate) }\end{array}$ & Measurement Quality \\
\hline \multirow[t]{2}{*}{$\begin{array}{l}\text { Other data requirements for } \\
\text { close-in-place and/or clean } \\
\text { closure alternative } \\
\text { (continued) }\end{array}$} & $\begin{array}{l}\text { Evaluate risk of groundwater contamination if TPH } \\
\text { concentrations above } 100 \mathrm{mg} / \mathrm{kg} \text {. }\end{array}$ & $\begin{array}{l}\text { If site conditions exceed the NAC } 459.9973 \\
\text { action level of } 100 \mathrm{mg} / \mathrm{kg} \text { TPH, the site } \\
\text { conditions will be evaluated in accordance } \\
\text { with NAC } 459.9973(1)(\mathrm{a}-\mathrm{k}) \text { factors to } \\
\text { determine if any corrective action will be } \\
\text { required. }\end{array}$ & Qualitative \\
\hline & Data Need: Resource availability. & $\begin{array}{l}\text { Conduct cost analysis of preferred closure } \\
\text { alternatives. }\end{array}$ & Qualitative \\
\hline $\begin{array}{l}\text { Additional data } \\
\text { requirements if clean } \\
\text { closure }\end{array}$ & $\begin{array}{l}\text { Data Need: Waste determination of any } \\
\text { remediated material. } \\
\text { Data Need: Volume of remediated material. } \\
\text { Data Need: Verification samples in areas of } \\
\text { remediation for established COCs. }\end{array}$ & $\begin{array}{l}\text { Collect the appropriate samples and submit } \\
\text { to laboratory for analysis. Calculate volume } \\
\text { of remediated material based on dimensions } \\
\text { of area with concentrations above PALs. }\end{array}$ & Quantitative \\
\hline
\end{tabular}

${ }^{\mathrm{a}}$ This column addresses the measurement quality assigned to all data collection activities and is determined by the intended use of the resulting data in decision making. The levels are assigned as quantitative, semiquantitative, and qualitative.

Quantitative data measures the quantity or amount of a characteristic or component within the population of interest. These data require the highest level of QA/QC in collection and measurement systems because the intended use of the data is to resolve primary decisions (i.e., rejecting or accepting the null hypothesis) and/or verifying closure standards have been met. Laboratory analytical data are usually assigned as quantitative data.

Semiquantitative data indirectly measures the quantity or amount of a characteristic or component of interest. Inferences are drawn about the quantity or amount of a characteristic or component because a correlation has been shown to exist between the indirect measurement and the results from a quantitative measurement. The QA/QC requirements on semiquantitative collection and measurement systems are high but may not be as rigorous as a quantitative measurement system.

Semiquantitative data contribute to decision-making but are not used alone to resolve primary decisions. The data are often used to guide investigations toward quantitative data collection.

Qualitative data identify or describe the characteristics or components of the population of interest. The QA/QC requirements are the least rigorous on data collection methods and measurement systems. Professional judgement is often used to generate qualitative data. The intended use of the data is for information purposes, to refine conceptual models, and to guide investigations rather than resolve primary decisions. This measurement of quality is typically assigned to historical information and data where $Q A / Q C$ may be highly variable or not known. 


\section{A.3.4 Step 4, Define the Boundaries of the Study}

The purpose of this step is to define the target population of interest and specify the spatial and temporal features of that population that are pertinent for decision making.

\section{A.3.4.1 Define the Target Population}

Two target populations have been identified for the mud pits and mud disposal landfill. One population is the COC concentrations within mud/soil cuttings from the surface to the textural discontinuity, while the second population consists of COC concentrations in the native soil below and adjacent to the textural discontinuity.

The target population for the septic system consists of COC concentrations for both the liquid and sludge phases of the septic tank; sludge/sediment within the distribution box/manhole; surface soil above the leachrock and soil below and adjacent to the leachrock/native soil interface within the leachfield; and soil adjacent to/beneath the septic tank and distribution box (e.g., outlet pipe, tank bottom).

\section{A.3.4.2 Determine the Spatial and Temporal Boundaries}

For Phase II, each mud pit CAS is considered geographically independent. This differs from Phase I, where each individual pit was independent. The geographic boundaries are further expanded laterally for Phase II to capture the potential extent of contaminant migration. Each CAS is defined by a 5-ft buffer zone around the berm, or the fenced edge of a crater regardless if bermed or not (see CAS figures in Section 2.0 of this report for approximate boundaries). The mud disposal landfill geographic boundary remains the crater diameter. Each mud pit can be divided into two strata: (1) surface of mud down to the textural discontinuity, and (2) soil below the textural discontinuity to a depth of $10 \mathrm{ft}$. The same strata apply to the mud disposal landfill; however, the second strata will be determined by the depth to bedrock, which is assumed less than $5 \mathrm{ft}$.

Geographic boundaries for the septic system are defined by the structures that comprise the system components such as the collection line piping, septic tank, manhole/distribution box, and the dimensions of leachfield (currently unknown). However, the lateral geographic boundaries are expanded to $15 \mathrm{ft}$ on all sides for Phase II to capture the potential extent of contaminant migration. 
The soils within the leachfield can be divided into two strata: (1) surface soils down to the top of the leachrock, and (2) soil below the leachrock/native soil interface to a depth of $10 \mathrm{ft}$.

Spatial boundaries have the potential to increase in size if the extent of contamination above PALs is shown to exist beyond these boundaries defined by the respective conceptual site model.

Temporal boundaries are those time constraints set up by weather conditions and project schedules set in the baseline. Weather conditions in Area 20 are an important temporal constraint and require that investigation activities not be scheduled during winter months. There are no time constraints on collecting samples because environmental conditions at all sites will not significantly change in the near future, and conditions would have stabilized over the last 10 to 25 years since the systems were last used. Current schedules for submitting the SAFER Plan are June 12, 2001, for the Draft SAFER Plan and August 28, 2001, for the Final SAFER Plan. Field work is currently scheduled to begin in Fiscal Year 2002.

\section{A.3.4.3 Identify Practical Constraints}

The NTS-controlled activities may affect ability to characterize this site. Underground utilities are expected to exist at the Area 3 Camp. Adverse weather conditions and health and safety concerns may affect this site. Certain health and safety hazards may exist in attempting to access the pits and septic tank. Area 20 is remote, which may create logistical constraints.

\section{A.3.4.4 Define the Scale of Decision Making}

The scales of decision making were defined so that individual CASs could be advanced to a Phase II characterization rather than submitting the entire CAU to a Phase II characterization. The decision scale also allows for corrective actions appropriate to each CAS rather than the entire CAU.

Scale for mud pits: Decision making will be based on each CAS as one unit such that both pits (if more than one) are closed in similar manner even though only one pit may contain contamination above PALs. This is based on recirculation processes used during drilling activities.

Scale for septic system: Decision making will be based on each individual component, such as septic tank versus leachfield soils. This allows for greater flexibility in corrective action alternatives. 


\section{A.3.5 Step 5, Develop a Decision Rule}

This step integrates outputs from previous steps with the inputs developed in this step into a decision rule ("If...then...") statement. This rule describes the conditions under which possible alternative actions would be chosen.

\section{A.3.5.1 Specify the Population Parameter}

The population parameter will be represented by the furthest extent of any COC at a concentration greater than or equal to PALs.

\section{A.3.5.2 Choose an Action Level}

Action levels were previously addressed in Step 3 of Phase I (see Section A.2.3.1).

\section{A.3.5.3 Measurement and Analysis Methods}

The same measurement and analysis methods used in Phase I will be applied in Phase II and were previously addressed in Step 3 (see Section A.2.3.2).

\section{A.3.5.4 Decision Rule}

If the laboratory analytical results determine that COC concentrations of soils are below the PALs, then stop the investigation and determine appropriate closure options. If COC concentrations are equal to or greater than PALs, then continue the lateral and/or vertical investigation to next appropriate sampling interval(s).

If the extent of COC concentrations above PALs exceeds the proposed spatial boundaries, then recommend the conceptual model be modified and further assessment be conducted to evaluate the new model. If the extent does not exceed the proposed spatial boundaries, then recommend the conceptual model does not need to be modified, further assessment is not necessary, and determine the appropriate corrective action alternative for site closure.

If verification samples collected for clean closure have COC concentrations below PALs, then remediation is complete. If the samples show COC concentrations equal to or above PALs, then continue to remediate soil and collect verification samples until COC concentrations are below PALs. 


\section{A.3.6 Step 6, Specify Tolerable Limits on Decision Errors}

Based on the understanding of current conditions documented in the CSM, the sampling approach for the Phase II investigation relies upon biased samples; therefore, statistical analysis is not appropriate.

The baseline condition and alternative condition for Phase II are:

- Baseline condition - COC concentrations are above PALs but have migrated beyond the spatial boundaries.

- Alternative condition - COC concentrations are above PALs but have not migrated beyond the spatial boundaries.

\section{A.3.6.1 False Rejection Decision Error}

False rejection (alpha error) would mean deciding that COC concentrations present have not migrated beyond the spatial boundaries, when they really do. This decision error would result in an increased risk to human health by not determining the full extent of contamination; thereby implementing an inappropriate corrective action at the site that would not adequately protect against exposure to future receptors.

Two basic assumptions regarding the area of contamination contribute to minimizing the chances of making a false rejection (alpha) decision error. The first is that the area of contamination is contiguous, and secondly that the extent of COC concentration decreases away from the area of contamination. The criteria for bounding the extent of contamination greater than PALs requires that two consecutive lateral and vertical samples, collected and submitted to the laboratory for analysis, show analytical results below PALs. Established QA/QC and procedures help minimize falsenegative analytical results.

\section{A.3.6.2 False Acceptance Decision Error}

False acceptance (beta error) would mean deciding that COC concentrations present have migrated beyond the spatial boundaries, when they really do not. The consequence of this decision error would result in an unnecessary increase in the utilization of resources in implementing an inappropriate corrective action. 
The false acceptance decision error is controlled by protecting against false-positive analytical results. False-positive results are typically attributed to laboratory errors and sampling/handling errors. Quality assurance/quality control samples such as field blanks, trip blanks, laboratory control samples, and method blanks should minimize the risk of a false-positive analytical result. Other factors are using clean sampling equipment and containers, following established procedures, and the history of similar sites with low beta errors.

\section{A.3.6.3 Quality Assurance/Quality Control}

A discussion of QA/QC is provided in Section A.2.6.3.

\section{A.3.7 Step 7, Optimize the Design for Obtaining Data}

The sampling strategies outlined below will ensure that the lateral and vertical extent of the contamination has been adequately located, identified, and quantified.

\section{A.3.7.1 Phase II}

Phase II efforts will consist of further characterizing sites where COCs were confirmed to be present above PALs during the Phase I activities. Laboratory analytical results from this phase will be used to determine where the extent of contamination has decreased below PALs. Only the COCs determined to be present in Phase I will be analyzed for during a Phase II characterization effort. It is important to note that the target population(s) to be investigated in Phase II are or may be different than those in Phase I; the target populations for this phase are documented in the relevant sections below.

Environmental soil samples may be field screened to guide sample collection activities, to assist in waste management decisions, and to provide health and safety information provided that the COCs identified in Phase I have an appropriate screening method. Field-screening methods and field-screening levels will be documented prior to the start of sampling activities.

\section{A.3.7.2 CAS 03-04-01, Area 3 Change House Septic System}

Phase II activities for the septic system will consist of conducting additional characterization of one or both leachfields to determine the extent of contamination. Sample collection will target the following populations: the COC concentrations of surface soil above the leachrock, and soil below and adjacent to the leachrock/native soil interface within the leachfield. 
To investigate the vertical and lateral extent of contamination, subsurface samples will be collected from below the leachrock/native soil interface at each sample location. Each sample collected will be submitted to the laboratory for analysis. Due to the potential for overflow conditions, surface samples will also be collected from each location at the fenced leachfield only. Initial sample locations are tentatively planned for all corners of the leachfield(s) within the physical boundaries, with step-out locations to be determined by site conditions. Figure A.3-1 shows the tentative locations for Phase II sampling. If a breach of any kind is identified within the fenced leachfield boundary, a step-out will be positioned at that location to capture the greatest potential for overflow contamination. Vertical samples will also be collected at the sample location with the highest concentrations above PALs identified during the Phase I investigation.

Extent of contamination is the area of contiguous contamination with COC concentrations above PALs. Lateral and vertical extent of contamination will be bounded by laboratory analytical results that show concentrations of COCs below PALs. If any of the step-out analytical results indicate COCs are still present, then additional step-out locations will be sampled until it can be demonstrated that COC concentrations below PALs have been achieved. If results indicate the extent of contamination extends beyond $50 \mathrm{ft}$ of the spatial boundaries, the conceptual model has failed and the investigation may need to be rescoped.

\section{A.3.7.3 CASs 03-09-01, 03-09-03, 03-09-04, and 03-09-05, Mud Pits and Mud Pit Spill Over}

Subsurface soil sampling will be conducted to determine the extent of COC contamination. Hand auguring, backhoe excavation, or direct-push will be the primary investigation techniques for these CASs. If the vertical extent of contamination is deeper than the limits of these techniques, then an appropriate drilling technique will be used.

To investigate the vertical and lateral extent of contamination, subsurface samples will be collected from below the textural discontinuity at each sample location. Each sample will be submitted to the laboratory for analysis for the COCs identified in Phase I. Initial sample locations are tentatively planned for all corners of the mud pits within the physical boundaries with step-out locations to be determined by site conditions. Figure A.3-1 shows the tentative locations for the first two sets of locations. 


\section{Mud Pit Sampling Strategy, Phase II}

$x$-Section view

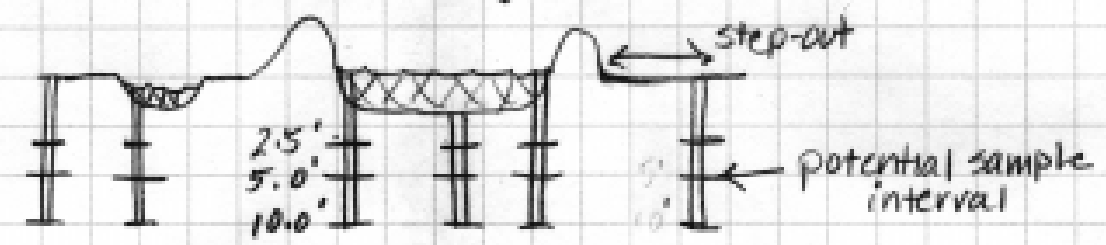

PlanView
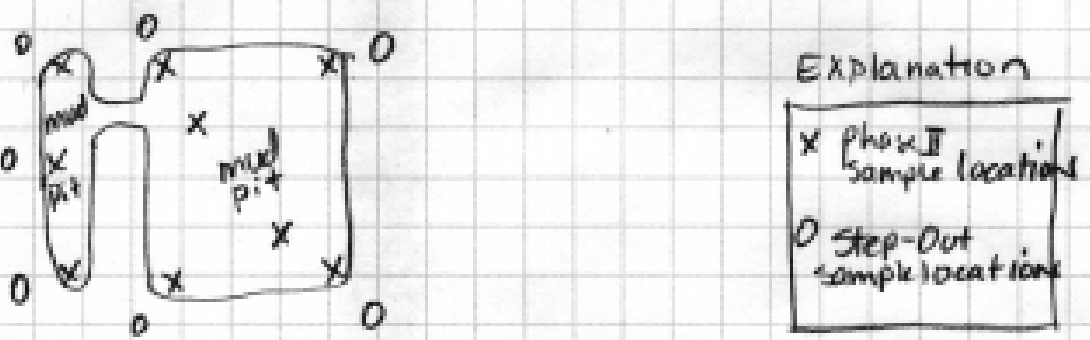

Leachfield Sampling Strategy, Phax II

Plan View o

\section{$x$-Section Viaw}
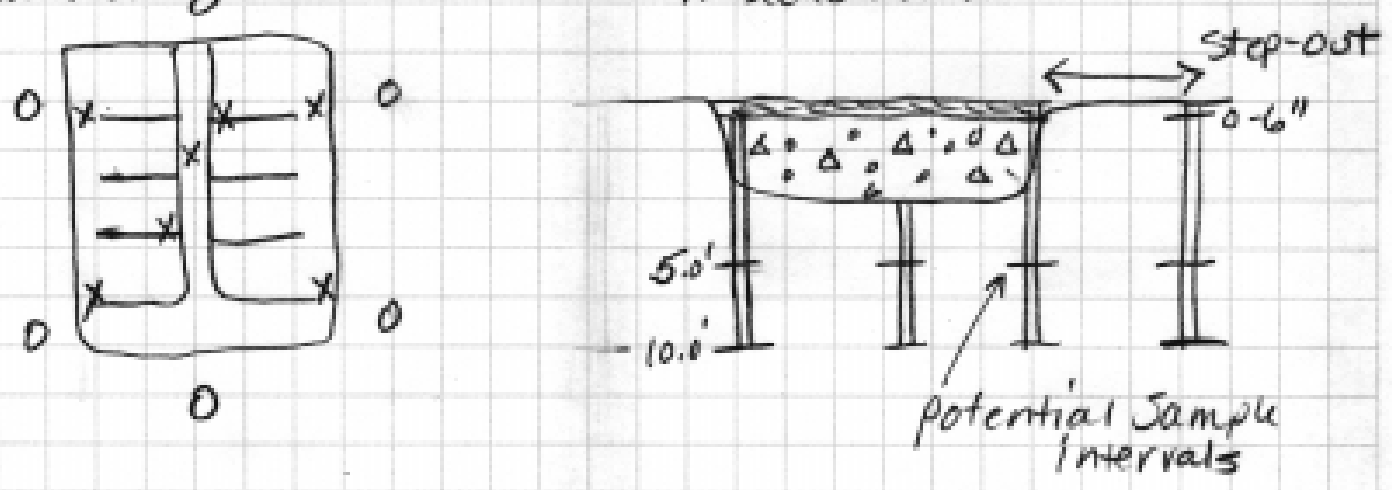

Figure $A .3-1$

Preliminary Phase II Sampling Strategies 
Extent of contamination is the area of contiguous contamination with COC concentrations above PALs. Lateral and vertical extent of contamination will be bounded by laboratory analytical results that show concentrations of COCs below PALs. If any of the step-out analytical results indicate COCs are still present, then additional step-out locations will be sampled until it can be demonstrated that COC concentrations below PALs have been achieved. If results indicate the extent of contamination extends beyond $50 \mathrm{ft}$ of the spatial boundaries, the conceptual model has failed and the investigation may need to be rescoped.

\section{A.3.8 CAS 20-16-01, Landfill}

Subsurface soil sampling will be conducted to determine the extent of COC contamination. Hand auguring or other manual means will be the primary investigation technique for this CAS. Due to the geographic access limitations of this site, excavation or direct-push techniques are not feasible.

To investigate the vertical and lateral extent of contamination, an attempt will be made to collect samples from below the textural discontinuity at each sample location. Each sample will be submitted to the laboratory for analysis for the COCs identified in Phase I. The lateral and vertical extent of contamination will be bounded by laboratory analytical results that show concentrations of COCs below PALs. If any of the step-out analytical results indicate COCs are still present, then additional step-out locations will be sampled until it can be demonstrated that COC concentrations below PALs have been achieved. If bedrock refusal is encountered before the extent has been determined, the investigation will stop and the conceptual model reevaluated. 


\section{A.4.0 References}

Adams, S., IT Corporation. 2000. Memorandum to B. Bailey (IT Corporation) entitled, "Radiological Contaminants of Potential Concern in Nevada Test Site Mud Pits," 30 November. Las Vegas, NV.

AEC, see Atomic Energy Commission.

Allchem.com, Inc. 2001. Chemical description of Paraformaldehyde [30525-89-4]. Found on the internet at allchem.com/Specs/Industrial/paraformaldehyde/.html as accessed on 11 January.

Atlan-Tech. 1992. Environmental Monitoring Report for the Proposed Ward Valley, California, LLRW Facility. Rosewall, GA.

Black, S.C., and Y.E. Townsend. 1996. U.S. Department of Energy Nevada Operations Office, Environmental Data Report for the Nevada Test Site - 1994.

Bordelois, B., Science Applications International Corporation. 1998a. Memo to R. Jackson (IT Corporation) entitled, "CAU 356, CAS 03-09-01 Sampling Report," 24 March. Las Vegas, NV.

Bordelois, B., Science Applications International Corporation. 1998b. Memo to R. Jackson (IT Corporation) entitled, "CAU 356, CAS 03-09-03 Sampling Report," 20 March. Las Vegas, NV.

Bordelois, B., Science Applications International Corporation. 1998c. Memo to R. Jackson (IT Corporation) entitled, "CAU 356, CAS 03-09-04 Sampling Report," 9 April. Las Vegas, NV.

Bull, R., Science Applications International Corporation. 2001. Memorandum to D. Arnold (SAIC) entitled, "Preliminary Assessment Data for CAU 356," 11 June. Las Vegas, NV: IT Corporation.

Chemfinder.com. 2001a. Chemical description of Caustic Soda [1310-73-2]. Found on the internet at chemfinder.com/reult.asp as accessed on 11 January. Cambridge, MA: Cambridge Soft Corporation.

Chemfinder.com. 2001b. Chemical description of Lithium Hypochlorite [13840-33-01]. Found on the internet at chemfinder.com/reult.asp as accessed on 11 January. Cambridge, MA: Cambridge Soft Corporation. 
Chemfinder.com. 2001c. Chemical description of Sodium Acid Pyrophosphate [7758-16-9]. Found on the internet at chemfinder.com/reult.asp as accessed on 11 January. Cambridge, MA: Cambridge Soft Corporation.

DOE, see U.S. Department of Energy.

DOE/NV, see U.S. Department of Energy, Nevada Operations Office.

DRI, see Desert Research Institute.

Desert Research Institute. 1988. CERCLA Preliminary Assessment of DOE's Nevada Operations Office Nuclear Weapons Testing Areas, Volume I. Prepared for the U.S. Department of Energy, Nevada Operations Office. Las Vegas, NV: Water Resources Center.

Desert Research Institute. 1996. Nevada Test Site Water-Supply Wells, DOE/NV/10845--86. Prepared by D. Gillespie, D. Jonathan, and P. Seaber. Reno, NV: Water Resources Center.

EPA, see U.S. Environmental Protection Agency.

FFACO, see Federal Facility Agreement and Consent Order.

Federal Facility Agreement and Consent Order. 1996 (as amended). Agreed to by the State of Nevada, the U.S. Department of Energy, and the U.S. Department of Defense. Las Vegas, NV.

Forsgren, F., HSI GeoTrans, Inc. 1998. Memorandum to R. Jackson (IT Corporation) entitled, "CAU 356, CAS 03-09-05, Sampling Report," 14 April. Las Vegas, NV.

H\&N, Inc., see Holmes and Narver, Inc.

Haworth, O., Reynolds Electrical \& Engineering Co., Inc. 1990. Letter to J. Stewart (DOE/NV) entitled, "Area 3 Septic System Modification Information," 16 February. Las Vegas, NV.

Haworth, O., Reynolds Electrical \& Engineering Co., Inc. 1991. Letter to D. Watson (DOE/NV) entitled, “Area 3 Sewage Systems Options," 29 January. Las Vegas, NV.

Holmes \& Narver, Inc. 1962. Engineering drawing JS-003-096-M8.1, entitled, "Skid Mounted Machine Shop Mechanical Plan \& Section,” 24 January. Las Vegas, NV.

Holmes \& Narver, Inc. 1988. Engineering drawing JS-003-054-C1, entitled, “Area 3 Camp Facilities Water and Sewer Distribution,” 12 September. Las Vegas, NV.

IT, see IT Corporation.

IT Corporation. 2001. Field Activity Daily Log from a field visit to sites in CAU 356, 13 March. Las Vegas, NV. 
LANL, see Los Alamos National Laboratory.

Los Alamos National Laboratory. 1991. Survey of Hazardous Materials Used in Nuclear Testing. Prepared by E.A. Bryant and J. Fabryka-Martin. Los Alamos, NM.

Marshall, D., Bechtel Nevada. 2001a. Interview with A. Dudley (SAIC) concerning Area 3 Camp facilities, 28 March. Las Vegas, NV.

Marshall, D., Bechtel Nevada. 2001b. Interview with A. Dudley (SAIC) concerning Area 3 Camp facilities, 29 March. Las Vegas, NV.

McArthur, R.D., and F.L. Miller. 1989. Off-Site Radiation Exposure Review Project (ORERP), Phase II Soil Program, DOE/NV/10384-23. Las Vegas, NV: Desert Research Institute.

Meyers, J.S., and T.J. Nordenson. 1962. Evaporation from the 17 Western States, with a Section on Evaporation Rates, USGS-PP-272-D. Reston, VA: U.S. Geological Survey.

Moore, J. 1999. Memorandum to M. Todd (SAIC), entitled, "Background Concentrations for NTS and TTR Soil Samples," 3 February. Las Vegas, NV: IT Corporation.

NAC, see Nevada Administrative Code.

NBMG, see Nevada Bureau of Mines and Geology.

Nevada Administrative Code. 2000a. NAC 444, "Sanitation.” Carson City, NV.

Nevada Administrative Code. 2000b. NAC 445A.2272, "Contamination of Soil: Establishment of Action Levels." Carson City, NV.

Nevada Bureau of Mines and Geology. 1998. Mineral and Energy Resource Assessment of the Nellis Air Force Range, Open-File Report 98-1. Reno, NV.

RSN, see Raytheon Services Nevada.

Racine, B., Mercury Blue Print \& Supply Co. 2001. Interview with A. Dudley (SAIC) concerning blueprinting chemicals, 28 March. Las Vegas, NV.

Raytheon Services Nevada. 1995. Engineering drawing, SK-003-95-C86, "Environmental Concerns 201-233." Mercury, NV: Archives and Records Center.

REECo, see Reynolds Electrical \& Engineering Co., Inc.

Reynolds Electrical \& Engineering Co., Inc. 1967. Engineering drawing, 3-C5, "Support Facilities As Built." Mercury, NV: Archives and Records Center. 
Reynolds Electrical \& Engineering Co., Inc. 1990. Engineering drawing, 3-SL-C1, "Modification Area 3 Camp Sewage Facility Site Plan.” Las Vegas, NV.

Reynolds Electrical \& Engineering Co., Inc. 1994. Area 3 Waste Impoundment, Historical Information. Prepared by C.G. Postle. Las Vegas, NV.

Reynolds Electrical \& Engineering Co., Inc. 1995. Preliminary Characterization of Abandoned Septic Tank Systems, DOE/NV--414. Las Vegas, NV.

Rowe, P., Stone and Webster Incorporated. 2000. Record of telecon with J. Markowsky (SAIC) concerning Area 3, Mud Disposal Crater, 18 December. Las Vegas, NV.

Rowe, P., Stone and Webster Incorporated. 2001. Record of Telecon with Beatriz Bordelois (SAIC) concerning mud pits and cellars/sumps, 22 January. Las Vegas, NV.

Rogers, A., Lawrence Livermore National Laboratory (retired). 2001. Interview with A. Dudley (SAIC) concerning the Area 3 Camp Machine Shop, 2 April. Las Vegas, NV.

U.S. Department of Energy, Nevada Operations Office. 1996a. Final Environmental Impact Statement for the Nevada Test Site and Off-site Locations in the State of Nevada. Las Vegas, NV.

U.S. Department of Energy, Nevada Operations Office. 1996b. Industrial Sites Quality Assurance Project Plan, DOE/NV--372. Las Vegas, NV.

U.S. Department of Energy, Nevada Operations Office. 1997. Corrective Action Investigation Plan for Central Nevada Test Area, CAU No. 417, DOE/NV--450. Las Vegas, NV.

U.S. Department of Energy, Nevada Operations Office. 1998. Work Plan for Leachfield Corrective Action Units: Nevada Test Site and Tonopah Test Range, Nevada, Rev. 1, DOE/NV--514. Las Vegas, NV.

U.S. Department of Energy, Nevada Operations Office. 1999a. Corrective Action Decision Document/Closure Report for Corrective Action Unit 266: Area 25 Building 3124 Leachfield, Nevada Test Site, Nevada, Rev. 0, DOE/NV--577. Las Vegas, NV.

U.S. Department of Energy, Nevada Operations Office. 1999b. Corrective Action Decision Document for Corrective Action Unit 261: Area 25 Test Cell A Leachfield System, Nevada Test Site, Nevada, Rev. 0, DOE/NV--583. Las Vegas, NV.

U.S. Department of Energy, Nevada Operations Office. 1999c. Corrective Action Decision Document for Corrective Action Unit 417: Central Nevada Test Area Surface, Nevada, Rev. 1, DOE/NV-524, April. Las Vegas, NV. 
U.S. Department of Energy, Nevada Operations Office. 1999d. Nevada Environmental Restoration Project, Salmon Site Remedial Investigation Report. Las Vegas, NV.

U.S. Department of Energy, Nevada Operations Office. 2000a. Corrective Action Decision Document for Corrective Action Unit 428: Area 3 Septic Systems 1 and 5, Tonopah Test Range, Nevada, Rev. 0, DOE/NV--587. Las Vegas, NV.

U.S. Environmental Protection Agency. 2000a. Guidance for the Data Quality Objectives Process, EPA QA/G-4. Washington, DC.

U.S. Environmental Protection Agency. 2000b. Memorandum from S.J. Smucker to PRG table mailing list regarding Region 9 Preliminary Remediation Goals (PRGs), 1 October.

San Francisco, CA.

U.S. Geological Survey. 1969. Summary Geologic Report on the U20b Emplacement Hole, Pahute Mesa, Nevada Test Site, SS-80, USGS-474-35. Official Use Only. Denver, CO.

U.S. Geological Survey. 1970. Report of Exploration Progress, Pahute Mesa, January 31, 1968 October 1, 1969, SS-I-23-17, USGS-474-70. Denver, CO.

Watson, D., U.S. Department of Energy. 1990. Letter to O. Haworth (REECo) entitled, "Area 3 Septic System,” 23 August. Las Vegas, NV.

Wilkes, M., Bechtel Nevada. 2000a. Record of meeting with B. Bailey (IT) regarding mud pits at the NTS, 3 November. Las Vegas, NV.

Wilkes, M., Bechtel Nevada. 2000b. Record of meeting with B. Bailey (IT) regarding mud pits at the NTS, 9 November. Las Vegas, NV.

Witt, J., Science Applications International Corporation. 2000a. Record of meeting with B. Bailey (IT) concerning mud pit usage, 19 October. Las Vegas, NV.

Witt, J., Science Applications International Corporation. 2000b. Record of meeting with K. Sculthorpe (SAIC) concerning mud pits, 9 November. Las Vegas, NV.

Wuellner, J.W., Reynolds Electrical \& Engineering Co., Inc. 1994. Memorandum to J.R. Bielawski (REECo) entitled, "Historical Information, Area 3 Waste Mud Impoundment," 2 May. Las Vegas, NV. 


\section{Attachment 1}

\section{CAU 356 Constituents Used in Drilling Mud}




\section{Table ATT.1-1 \\ Constituents Used in Drilling Mud}

(Page 1 of 2)

\begin{tabular}{|c|c|c|c|}
\hline Product & Company & Chemical Material & Reference \\
\hline My-Lo-Gel & Dresser Industries & Pregelatanized starch & REECo, 1994; LANL, 1991 \\
\hline M-I Gel (Bentonite) & \multirow{2}{*}{ M-I Drilling Fluids Co. } & Unknown & REECo, 1994 \\
\hline Bentonite/Polyacrylamide & & Unknown & REECo, 1994 \\
\hline Bentonite, Swell Gel & Redmond Clay and Salt & Unknown & REECo, 1994 \\
\hline Sepiolite Clay & IMV Div. of Floridan Co. & $\mathrm{Mg}_{4} \mathrm{Si}_{6} \mathrm{O}_{15}(\mathrm{OH})_{2}+6 \mathrm{H}_{2} \mathrm{O}$ & REECo, 1994 \\
\hline EZ Mud-DP & Baroid Drilling Fluids, Inc. & Polymer & REECo, 1994 \\
\hline Soda Ash & Texas Gulf, Inc. & $\begin{array}{l}\text { Theophylline, } \\
\text { ethylenediamine, carbonic } \\
\text { acid, disodium salt }\end{array}$ & REECo, 1994; LANL, 1991 \\
\hline Potash & TexasGulf Chemicals Co. & $97 \% \mathrm{KCl}$ & REECo, 1994; LANL, 1991 \\
\hline Surfactant TF Foamer & Thatcher Chemical Co. & Isopropanol & REECo, 1994; LANL, 1991 \\
\hline Guar Gum G-150 & Rantee Corp. & Unknown & REECo, 1994 \\
\hline Lithium Hypochlorite & FMC Corp. & ClLiO & $\begin{array}{l}\text { REECo, 1994; } \\
\text { Chemfinder.com, 2001b }\end{array}$ \\
\hline Rapid Mud & Dresser Industries & $\begin{array}{l}\text { Liquid anionic polyelectrolyte } \\
\text { (organic) }\end{array}$ & REECo, 1994; LANL, 1991 \\
\hline Cydril 4000 Flocculant & American Cyanamid Co. & Anionic polyacrylamide & REECo, 1994; LANL, 1991 \\
\hline Sodium Acid Pyrophosphate & Nusource Chemical Corp. & $\mathrm{H}_{2} \mathrm{Na}_{2} \mathrm{O}_{7} \mathrm{P}_{2}$ & $\begin{array}{l}\text { REECo, 1994; } \\
\text { Chemfinder.com, 2001c }\end{array}$ \\
\hline Lithium Bromide & Lithium Corp. of America & $\mathrm{LiBr}$ & REECo, 1994 \\
\hline Paraformaldehyde & \multirow{6}{*}{ Dresser Industries } & {$\left[\mathrm{CH}_{2} \mathrm{O}\right]_{\mathrm{n}}$} & $\begin{array}{l}\text { REECo, 1994, } \\
\text { Allchem.com, } 2001\end{array}$ \\
\hline Magco Foam Check & & Proprietary mixture & REECo, 1994; LANL, 1991 \\
\hline Cypan & & $\begin{array}{l}\text { Sodium polyacrylate } \\
\text { (polymer) }\end{array}$ & REECo, 1994; LANL, 1991 \\
\hline Caustic Soda Flake & & $\mathrm{NaOH}$ & REECo, 1994; LANL, 1991 \\
\hline Magcocide & & $\begin{array}{l}\text { 91\% Paraformaldehyde (EPA } \\
\text { Hazardous Chemical) }\end{array}$ & REECo, 1994; LANL, 1991 \\
\hline My-Lo-Gel Preservative & & $\begin{array}{l}\text { 95\% Paraformaldehyde (EPA } \\
\text { Hazardous Chemical) }\end{array}$ & REECo, 1994; LANL, 1991 \\
\hline Thermogel & Unknown & Sepiolite & LANL, 1991 \\
\hline Pela Caustic Soda Beads & Dyce Chemical Co. & $\mathrm{HNaO}$ & $\begin{array}{l}\text { REECo, 1994; } \\
\text { Chemfinder.com, 2001a }\end{array}$ \\
\hline
\end{tabular}


Table ATT.1-1

Constituents Used in Drilling Mud

(Page 2 of 2)

\begin{tabular}{|l|l|l|l|}
\hline \multicolumn{1}{|c|}{ Product } & \multicolumn{1}{|c|}{ Company } & \multicolumn{1}{c|}{ Chemical Material } & \multicolumn{1}{c|}{ Reference } \\
\hline \hline Sodium Polyacrylate - Spar & Dixie Chemical Co. & Unknown & REECo, 1994 \\
\hline Guar Gum & Polychem International & Galacto-mannans $\left(\mathrm{C}_{6} \mathrm{H}_{10} \mathrm{O}_{5}\right)_{\mathrm{n}}$ & REECo, 1994; LANL, 1991 \\
\hline Nalco ASP-715 & Nalco Chemical Co. & Unknown & REECo, 1994 \\
\hline $\begin{array}{l}\text { Stepantan 29N Foaming } \\
\text { Agent }\end{array}$ & Stepan Chemicals & Unknown & REECo, 1994 \\
\hline Magconol & Magcobar & Alcohol & LANL, 1991 \\
\hline Raykrome 400 & Unknown & $\begin{array}{l}\text { Chrome lignosulfonate, } \\
\text { contains 4\% Cr }\end{array}$ & LANL, 1991 \\
\hline Polysal & Unknown & Modified starch & LANL, 1991 \\
\hline $\begin{array}{l}\text { Hydrogel, Big Horn, or } \\
\text { Envirogel }\end{array}$ & Unknown & $\begin{array}{l}\text { Sodium montmorillonite, } \\
\text { Western Bentonite }\end{array}$ & LANL, 1991 \\
\hline
\end{tabular}


Appendix B

\section{Project Organization}




\section{B.1.0 Project Organization}

The NNSA/NV Industrial Sites Project Manager is Janet Appenzeller-Wing and her telephone number is (702) 295-0461. The NNSA/NV Industrial Sites Task Manager is Kevin Cabble and his telephone number is (702) 295-5000.

The names of the project Health and Safety Officer and the Quality Assurance Officer can be found in the appropriate NNSA/NV plan. However, personnel are subject to change, and it is suggested that the NNSA/NV Industrial Sites Project Manager be contacted for further information. The NNSA/NV Task Manager will be identified in the FFACO Biweekly Activity Report prior to the start of field activities. 


\section{Appendix C}

\section{NDEP Comment Responses}


NEVADA ENVIRONMENTAL RESTORATION PROJECT

DOCUMENT REVIEW SHEET

\begin{tabular}{|c|c|c|c|c|c|}
\hline \multicolumn{4}{|c|}{$\begin{array}{l}\text { 1. Document Title/Number: Draft Streamlined Approach for Environmental Restoration (SAFER) Plan for } \\
\text { Corrective Action Unit 356: Mud Pits and Disposal Sites, Nevada Test Site, Nevada }\end{array}$} & \multicolumn{2}{|c|}{ 2. Document Date: June 2001} \\
\hline \multicolumn{4}{|c|}{ 3. Revision Number: 0} & \multicolumn{2}{|c|}{ 4. Originator/Organization: IT Corporation } \\
\hline \multicolumn{4}{|c|}{ 5. Responsible DOE/NV ERP Project Mgr.: Janet Appenzeller-Wing } & \multicolumn{2}{|c|}{ 6. Date Comments Due: July 21, 2001} \\
\hline \multicolumn{6}{|c|}{ 7. Review Criteria: Full } \\
\hline \multicolumn{4}{|c|}{ 8. Reviewer/Organization/Phone No.: NDEP } & \multicolumn{2}{|c|}{ 9. Reviewer's Signature: } \\
\hline $\begin{array}{l}\text { 10. Comment } \\
\text { Number/ } \\
\text { Location }\end{array}$ & 11. Type ${ }^{\star}$ & 12. Comment & \multicolumn{2}{|c|}{ 13. Comment Response } & 14. Accept \\
\hline 1. & & $\begin{array}{l}\text { NDEP reviewed the Draft Streamlined Approach for Environmental } \\
\text { Restoration (SAFER) Plan for Corrective Action Unit 356, Mud Pits } \\
\text { and Disposal Sites and had no comments to this document. }\end{array}$ & & & \\
\hline & & & & & \\
\hline & & & & & \\
\hline & & & & & \\
\hline & & & & & \\
\hline & & & & & \\
\hline & & & & & \\
\hline & & & & & \\
\hline
\end{tabular}

${ }^{a}$ Comment Types: $M=$ Mandatory, $S=$ Suggested

Return Document Review Sheets to DOE/NV Environmental Restoration Division, Attn: QAC, M/S 505. 


\section{Distribution}

*Provide copy in distribution of Revision 0 and subsequent revisions, if applicable. Copies of only the NDEP-approved document will be distributed to others.

Paul J. Liebendorfer

State of Nevada

Bureau of Federal Facilities

Division of Environmental Protection

333 W. Nye Lane, Room 138

Carson City, NV 89706-0851

Supervisor, Las Vegas Office

State of Nevada

Bureau of Federal Facilities

Division of Environmental Protection

555 E. Washington, Suite 4300

Las Vegas, NV 89101

Sabrina Lawrence

U.S. Department of Energy

National Nuclear Security Administration

Nevada Operations Office

Environmental Restoration Division

P.O. Box 98518, M/S 505

Las Vegas, NV 89193-8518

Janet Appenzeller-Wing

U.S. Department of Energy

National Nuclear Security Administration

Nevada Operations Office

Environmental Restoration Division

P.O. Box 98518, M/S 505

Las Vegas, NV 89193-8518

Kevin Cabble

U.S. Department of Energy

National Nuclear Security Administration

Nevada Operations Office

Environmental Restoration Division

P.O. Box 98518, M/S 505

Las Vegas, NV 89193-8518
2 (Controlled)*

1 (Controlled)*

1 (Controlled)*

1 (Uncontrolled)*

1 (Uncontrolled)* 
Wayne Johnson

1 (Uncontrolled)*

Bechtel Nevada

P.O. Box 98521, M/S NTS306

Las Vegas, NV 89193-8521

Brad Jackson

1 (Uncontrolled)*

Bechtel Nevada

P.O. Box 98521, M/S NTS306

Las Vegas, NV 89193-8521

Dawn Arnold

1 (Controlled)*

ITLV

P.O. Box 93838

Las Vegas, NV 89193

Jeff Johnson

1 (Controlled)*

ITLV

P.O. Box 93838

Las Vegas, NV 89193

IT Corporation Central Files

1 (Uncontrolled)*

P.O. Box 93838

Las Vegas, NV 89193

Manager, Southern Nevada FFACO

1 (Controlled)

Public Reading Room

1 (Uncontrolled)

P.O. Box 98521, M/S NLV040

Las Vegas, NV 89193-8521

Manager, Northern Nevada FFACO

1 (Uncontrolled)

Public Reading Room

Nevada State Library and Archives Federal Publications

100 North Stewart Street

Carson City, NV 89701-4285

FFACO Support Offices

1 (Controlled)

IT Corporation

P.O. Box 93838

Las Vegas, NV 89193 
Technical Information Resource Center

U.S. Department of Energy

National Nuclear Security Administration

Nevada Operations Office

P.O. Box 98518, M/S 505

Las Vegas, NV 89193-8518

U.S. Department of Energy

Office of Scientific and Technical Information

P.O. Box 62

Oak Ridge, TN 37831
1 (Uncontrolled)

1 (Uncontrolled, electronic copy) 